$$
\text { PNL- }-10848
$$

\title{
Assessment of Supply-Side Alternatives for the Handlova Heating System
}

October 1995

\section{AECEIVED \\ OCT 041996 \\ OSTI}

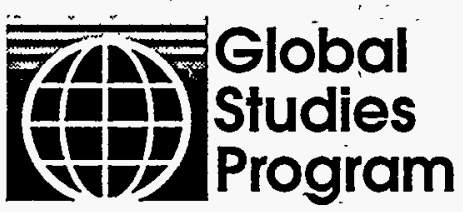

-Pacific Northwest Laboratory

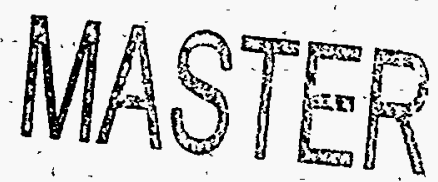

ASTRIBUTION OF THIS DOCUMENT IS UNLIMITED do 


\section{DISCLAIMER}

This report was prepared as an account of work sponsored by an agency of the United States Government. Neither the United. States Government nor any agency thereof, nor Battelle Memorial Institute, nor any of their employees, makes any warranty, express ó implied, or assumes any legal liability or responsibility for the accuracy, completeness, or 'usefulness : of any information, apparatus, product, or process disclosed, or represents that its use would not infringe privately owned rights. Reference herein to any specific commercial product; process, or service by trade name, tràdemark, manufacturer, or othèrwise does not necessarily constitute or imply its endorsement, recommendation, or favoring by the United States Government or any agency thereof; or Battelle Memorial lnstitute. The views and opinions of authors expressed herein do not necessarily state or reflect those of the United States Governmént or any agency thereof.

\section{PACIFIC NORTHWEST LABORATORY operated by \\ BATTELLE MEMORIAL INSTITUTE for the \\ UNITED STATES DEPARTMENTT OF ENERGY under Contract DE-ACOG-TGRLO 1830}


Assessment of Supply-Side Alternatives for the Handlova Heating System

October 1995

Prepared for the U.S. Department of Energy under Contract DE-AC06-76RLO 1830

Pacific Northwest Laboratory Washington, DC 20024 


\section{DISCLAIMER}

Portions of this document may be illegible in electronic image products. Images are produced from the best available original document. 


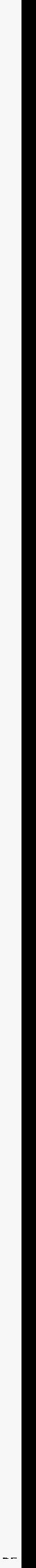




\section{ASSESSMENT OF SUPPLY-SIDE ALTERNATIVES FOR THE HANDLOVA HEATING SYSTEM}

\section{FEBRUARY 1994}

\section{Prepared by:}

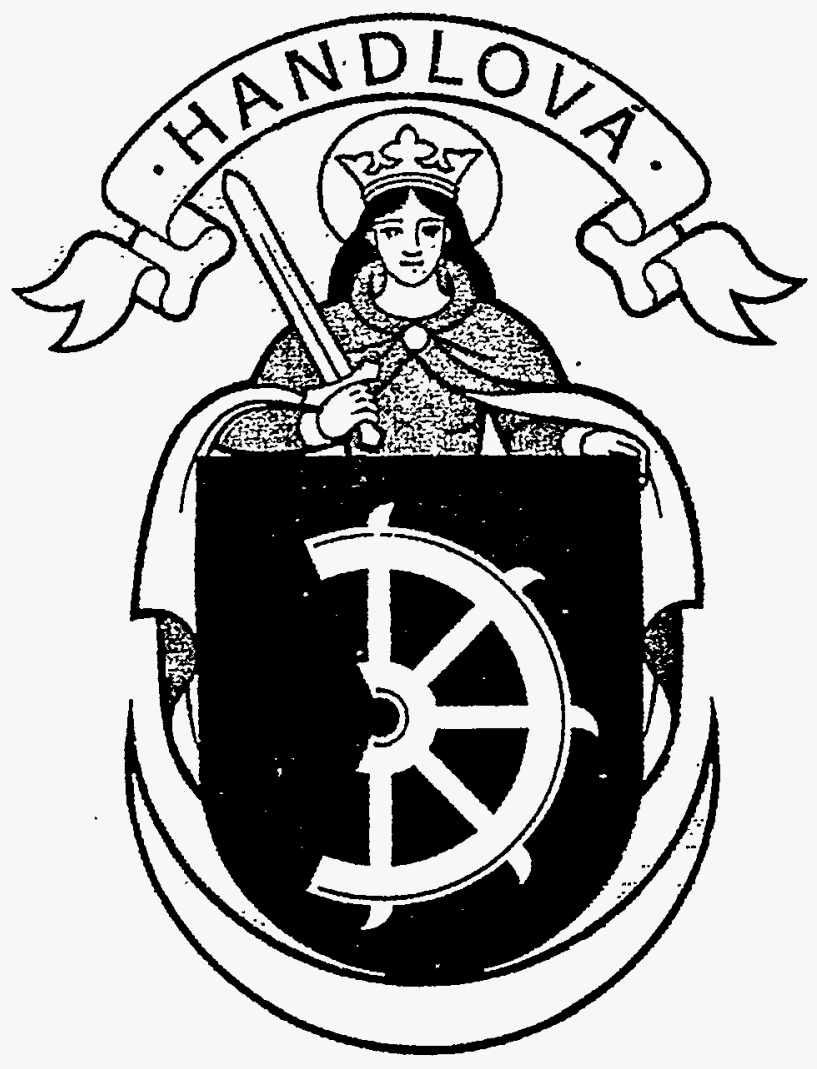

EGU Bratislava

\section{Under Contract With:}

Battelle, Pacific Northwest Laboratory

Assisted by:

Tecogen Division

Thermo Power Corporation 


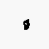




\section{TABLE OF CONTENTS}

SUMMARY

vii

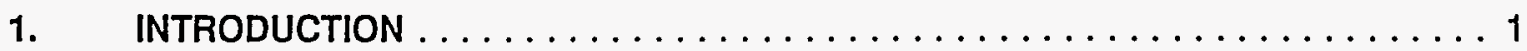

1.1 SCOPE AND APPROACH $\ldots \ldots \ldots \ldots \ldots \ldots \ldots \ldots \ldots \ldots \ldots \ldots \ldots \ldots \ldots$

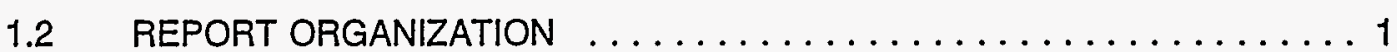

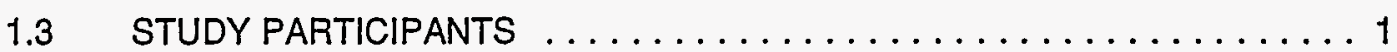

2. THE SUPPLY AND DEMAND SIDE ANALYSES $\ldots \ldots \ldots \ldots \ldots \ldots \ldots \ldots$

2.1 HISTORY AND CURRENT STATE OF THE THERMAL ENERGY

SUPPLY AND DEMAND $\ldots \ldots \ldots \ldots \ldots \ldots \ldots \ldots \ldots$

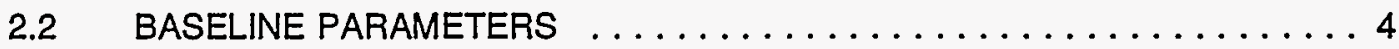

2.2.1 Energy Use Baseline and Demand Forecast $\ldots \ldots \ldots \ldots \ldots \ldots$

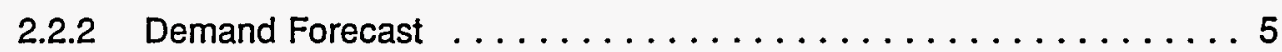

2.2 .3 Fuel Availability . . . . . . . . . . . . . . . 7

3. CENTRAL DISTRICT HEATING SYSTEM $\ldots \ldots \ldots \ldots \ldots \ldots \ldots \ldots$

3.1 DISTRIBUTION SYSTEM ANALYSIS $\ldots \ldots \ldots \ldots \ldots \ldots \ldots \ldots \ldots$

3.1.1 Distribution System with Central Pumping Station Only . . . . . . 8

3.1.2 Distribution System with Central Pumping Station and an Additional Pumping Station for Peak Operation . . . . . . . 11

3.1.3 Heat Exchanger Stations . . . . . . . . . . . . 13

3.2 ALTERNATIVE 1 : CENTRAL DISTRICT HEATING SYSTEM WITH COGENERATION AND COAL/GAS FUEL $\ldots \ldots \ldots \ldots \ldots \ldots$

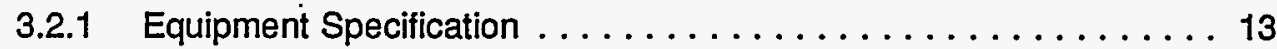

3.2.2 Investment for Heating Plant Reconstruction $\ldots \ldots \ldots \ldots \ldots \ldots$

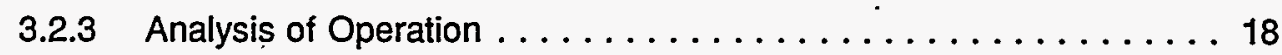

3.2.4 Economic Analysis . . . . . . . . . . . . . . . . . . 22

3.2.4.1 Method Used . . . . . . . . . . . . . . . . . 25

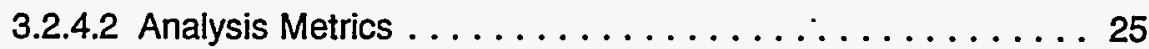

3.2.4.3 Project Economic Analysis . . . . . . . . . 26 
3.3 ALTERNATIVE 2 : CENTRAL DISTRICT HEATING SYSTEM WITH

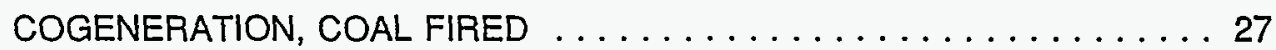

3.3.1 Equipment Specification . . . . . . . . . . . . . . 27

3.3.2 Investment for Heating Plant Reconstruction . . . . . . . . . 33

3.3.3 Analysis of Operation . . . . . . . . . . . . . . 33

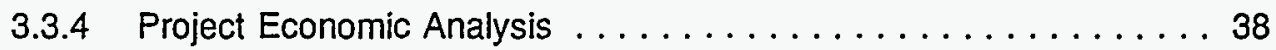

4. DECENTRALIZED HEAT SUPPLY SYSTEM $\ldots \ldots \ldots \ldots \ldots \ldots \ldots \ldots \ldots$

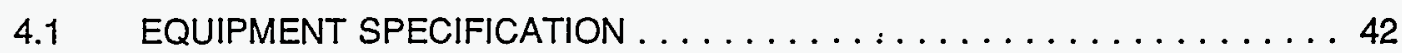

4.1 .1 Boiler Rooms . . ... . . . . . . . . . . . . . 42

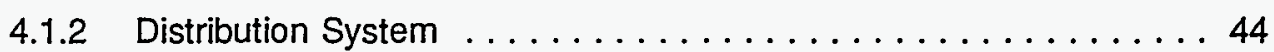

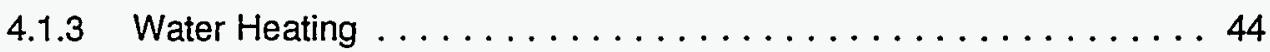

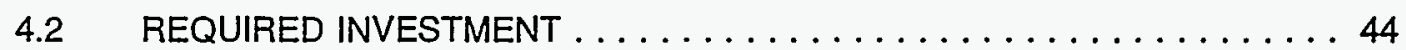

4.3 ANALYSIS OF OPERATION $\ldots \ldots \ldots \ldots \ldots \ldots \ldots \ldots \ldots \ldots$

4.4 PROJECT ECONOMIC ANALYSIS $\ldots \ldots \ldots \ldots \ldots \ldots \ldots \ldots$

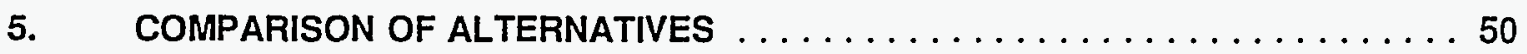

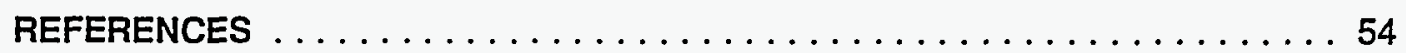

APPENDIX A $\ldots \ldots \ldots \ldots \ldots \ldots \ldots \ldots \ldots \ldots \ldots \ldots \ldots \ldots \ldots \ldots \ldots$

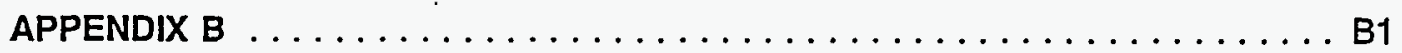

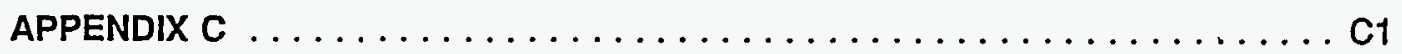




\section{LIST OF TABLES}

1. Technical and Economical Evaluation of Alternatives $\ldots \ldots \ldots \ldots \ldots \ldots \ldots$ viii

2.1 Energy End Use by Sectors and Fuels $\ldots \ldots \ldots \ldots \ldots \ldots \ldots \ldots \ldots \ldots$

2.2 Industrial User Energy Consumption, $1992 \ldots \ldots \ldots \ldots \ldots \ldots \ldots \ldots \ldots$

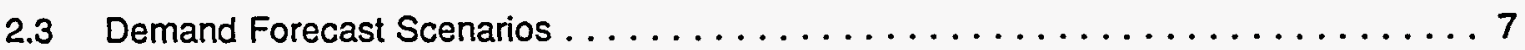

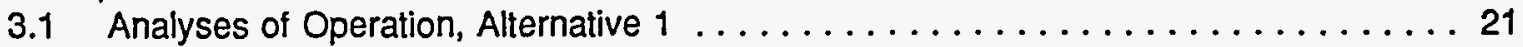

3.2 Production of Thermal Energy and Electricity $\ldots \ldots \ldots \ldots \ldots \ldots \ldots \ldots \ldots$

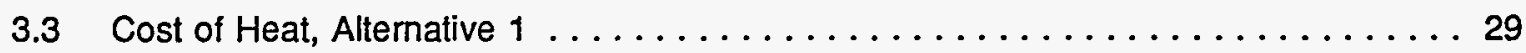

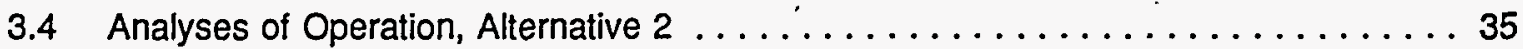

3.5 Production of Thermal Energy and Electricity $\ldots \ldots \ldots \ldots \ldots \ldots \ldots \ldots$

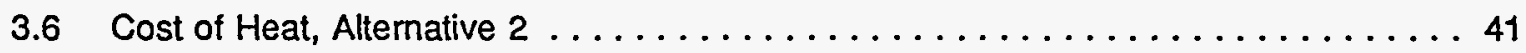

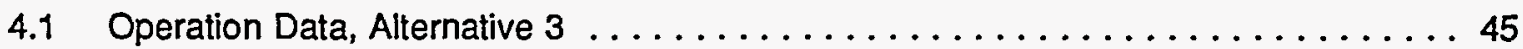

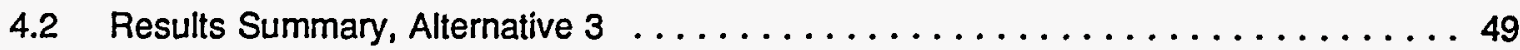

5.1 Technical and Economical Comparison of Alternatives $\ldots \ldots \ldots \ldots \ldots \ldots \ldots$

A.1 Cash Flow Summary, Alternative 1 , Variant $2 \ldots \ldots \ldots \ldots \ldots \ldots \ldots$ A2

A.2 Parameters of Economic Effectiveness, Alternative 1, Variant $2 \ldots \ldots \ldots \ldots \ldots$ A3

B.1 Cash Flow Summary, Alternative 2 , Variant $2 \ldots \ldots \ldots \ldots \ldots \ldots \ldots$

B.2 Parameters of Economic Effectiveness, Alternative 2, Variant $2 \ldots \ldots \ldots \ldots$ B3

C.1 Cash Flow Summary, Alternative $3 \ldots \ldots \ldots \ldots \ldots \ldots \ldots \ldots \ldots \ldots \ldots$

C.2 Parameters of Economic Effectiveness, Alternative $3 \ldots \ldots \ldots \ldots \ldots \ldots \ldots$ 


\section{LIST OF FIGURES}

1. Economic Analysis and Sensitivity of Results for Decentralized (Alt. 3) and Central (Alt. 1) Production of Thermal Energy for Space and Water Heating

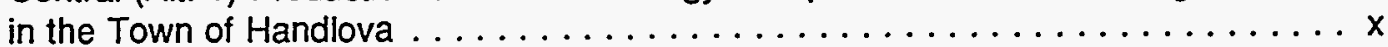

2. Natural Gas Prices Development $\ldots \ldots \ldots \ldots \ldots \ldots \ldots \ldots \ldots \ldots \ldots \ldots \ldots \ldots \ldots$

3. Electricity Prices Development $\ldots \ldots \ldots \ldots \ldots \ldots \ldots \ldots \ldots \ldots \ldots \ldots \ldots \ldots \ldots \ldots$

3.1 Layout of Central Heating System in Town of Handlova $\ldots \ldots \ldots \ldots \ldots \ldots$

3.2 Pressure Diagram of Main Distribution System $\ldots \ldots \ldots \ldots \ldots \ldots \ldots \ldots \ldots$

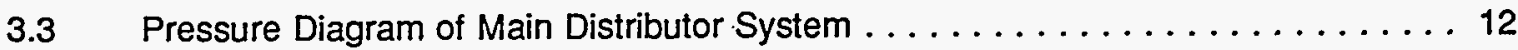

3.4 Basic Equipment Diagram for Alternative $1 \ldots \ldots \ldots \ldots \ldots \ldots \ldots \ldots \ldots$

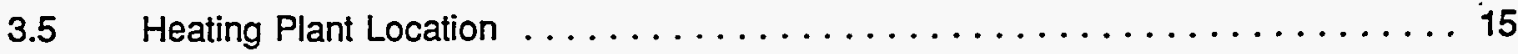

3.6 Load Duration Curve - Heat Supply Including Distribution Heat Losses,

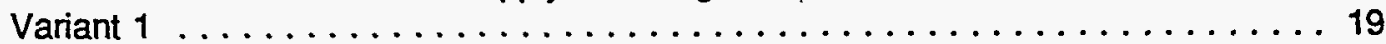

3.7 Load Duration Curve - Heat Supply Including Distribution Heat Losses,

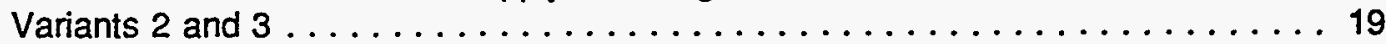

3.8 Load Duration Curve - Heat Supply Including Distribution Heat Losses,

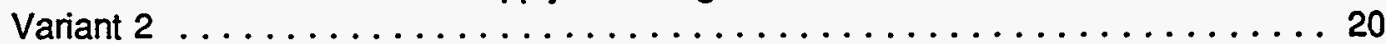

3.9 Load Duration Curve - Heat Supply Including Distribution Heat Losses,

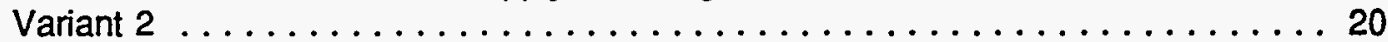

3.10 Load Duration Curve - Output Electricity Production, Variant $1 \ldots \ldots \ldots \ldots \ldots$

3.11 Load Duration Curve - Fuel Consumption, Variant $2 \ldots \ldots \ldots \ldots \ldots \ldots \ldots$

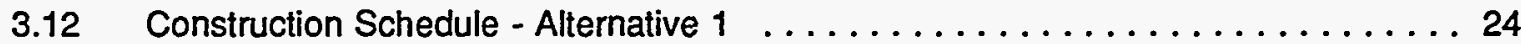

3.13 Cost of Heat as Function of Real Interest Rate and Inflation $\ldots \ldots \ldots \ldots \ldots . \ldots 28$

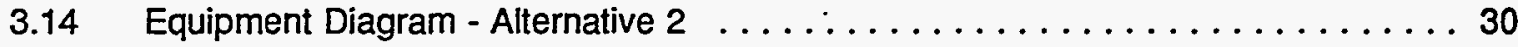

3.15 Load Duration Curve - Output Electricity Production, Variant $2 \ldots \ldots \ldots \ldots \ldots$. . . 34

3.16 Load Duration Curve - Fuel Consumption, Variant $2 \ldots \ldots \ldots \ldots \ldots \ldots$

3.17 Construction Schedule - Alternative $2 \ldots \ldots \ldots \ldots \ldots \ldots \ldots \ldots \ldots \ldots \ldots$

3.18 Cost of Heat as Function of Real Interest and Inflation $\ldots \ldots \ldots \ldots \ldots \ldots \ldots$

4.1 Construction Schedule - Alternative 3 (Decentralized) $\ldots \ldots \ldots \ldots \ldots \ldots \ldots$ 


\section{LIST OF FIGURES (Continued)}

$4.2 \quad$ Analysis of Delivered Energy Cost $\ldots \ldots \ldots \ldots \ldots \ldots \ldots$

5.1 Economic Analysis of Decentralized and Centralized Thermal

Energy Supply System . . . . . . . . . . . . . . . . . . . 51 
Mr. Andrew Popelka, Tecogen, and Ing. Peter Sestak, EGU Bratislava, would like to give special recognition to the following people who greatly contributed to the efforts of this project.

Gratitude is expressed to Len Rogers, U.S. Agency for International Development (AID), Marian Krsko, AID Slovak Mission, and Elaine Guthrie, U.S. Department of Energy, for making this study possible. Special thanks to Jaro Janicek at EGU Bratislava and Ed Doyle at Tecogen for their technical support and oversight. Recognition to Bill Chandler, Director of PNL's Advanced International Studies Unit, and Tom Secrest, Program Manager at PNL, for their guidance in this effort. Special appreciation to Kim Myles for the final preparation of this report. 


\section{SUMMARY}

\section{GOALS OF THE STUDY}

The goals of this study were to:

- $\quad$ perform technical and economical analyses for three alternatives for the production and distribution of thermal energy in the town of Handlova, Slovakia,

- $\quad$ perform an economic evaluation for the main parameters for each alternative at the given required rate of return,

- $\quad$ evaluate the sensitivity of the cost of delivered energy to several parameters, such as the thermal energy demand, cost of fuels and real interest rate, and

- provide this information to the town officials for their decisions about the future development of the heat supply for space heating and water heating in the residential and non-residential sectors.

\section{APPROACH}

The study consisted of several major activities with a specific approach to each activity. The demand side energy consumption data were acquired through a statistical collection and subsequent energy use intensity evaluation of the consumption of the individual energy users. The technical evaluation of the energy source was performed in accordance with the standard thermodynamic and hydraulic calculation methods. The information on the required investment was obtained by averaging the quotes from manufacturers of the equipment. Operation and maintenance costs were estimated based on data available from other similar operations. The evaluation of the economics was performed according to a discounted cash flow method.

\section{RESULTS}

Three alternative heat supply systems and three load variants were analyzed. Alternative 1 , which would use both coal and natural gas, and Alternative 2, which would use only coal, are both centralized district heating systems. Alternative 3, which would use only natural gas, is a decentralized heating system.

The comparison of the decentralized and centralized heat supply system alternatives evaluated in this study is presented in Table 1. For this comparison, the demand variant No. 2, from the demand side study of the centralized heat supply system, and a coal price of 680 SK were used. The coal price of $680 \mathrm{Sk}$ is a real 1993 coal price, escalated to year 1997. 
Table 1 - Technical and Economical Evaluation of Alternatives

\begin{tabular}{|c|c|c|c|c|}
\hline$\because$ P Parameter an a & Unit & Alt 1 & Alt 2 & Alt 3 \\
\hline \multirow{2}{*}{\multicolumn{5}{|c|}{$\begin{array}{l}\text { Technical Paramters } \\
\text { Boiler Output Installed }\end{array}$}} \\
\hline & & & & \\
\hline Steam & MWt & 60 & 90 & 1.5 \\
\hline Hot Water & MWt & 40 & -- & 55.5 \\
\hline Source Installed Output & MWe & 4.8 & 4.8 & $(.2-.3)$ \\
\hline System Peak Thermal Output Requirements & $\mathrm{MWt}$ & 70 & 70 & 42.5 \\
\hline \\
\hline \multicolumn{5}{|l|}{ Fuel Consumption } \\
\hline Coal & t/yr & 69,307 & 93,013 & --- \\
\hline Gas & mil.m3/yr & 3,947 & --- & 11,074 \\
\hline \multicolumn{5}{|l|}{ Internal Consumption } \\
\hline Electricity & MWh/yr & 1,790 & 2,180 & 500 \\
\hline Thermal Energy & GJ/yr & 110,234 & 94,209 & -- \\
\hline \multicolumn{5}{|l|}{ Delivered Energy } \\
\hline Thermal Energy & $\mathrm{GJ} / \mathrm{yr}$ & 530,050 & 530,050 & 377,280 \\
\hline Electricity & MWh/yr & 20,610 & 25,020 & -- \\
\hline \multicolumn{5}{|l|}{ Emissions Produced } \\
\hline $\mathrm{SO}_{2}$ & ton/yr & 1,073 & 1,518 & $\cdots$ \\
\hline $\mathrm{NO}_{x}$ & ton/yr & 266 & 344 & 14.58 \\
\hline Particulate & ton/yr & 25,212 & 47,334 & -- \\
\hline \multicolumn{5}{|l|}{ Economic Parameters } \\
\hline Total Investment (IN) & thous. SK & 300,500 & 261,500 & 229,554 \\
\hline Average Annual Net Profit & thous. SK & 23,366 & 20,448 & 18,787 \\
\hline Discounted Total Profit & thous. SK & 220,522 & 192,975 & 172,232 \\
\hline Discounted Total Cash Flow & thous. SK & 96,245 & 85,954 & 70,662 \\
\hline Simple Payback & years & 16 & 16 & 15 \\
\hline Cost of Delivered Energy & SK/GJ & 228.35 & 205.80 & 245.30 \\
\hline Number of Jobs & -- & 55 & 55 & 7 \\
\hline
\end{tabular}


The comparison shows that Alternative 2 (coal and gas fueled central heat supply system) offers the lowest delivered thermal energy cosi of 205.80 SK/GJ. It also offers approximately 55 jobs in the central heating system operation and can help to maintain 1,000 to 1,400 jobs in the coal mine. Coal mine jobs do not solely depend on the town's heat supply system; another market can be found for all coal grades produced by the coal mine.

Figure 1 shows the comparison of the cost of delivered thermal energy for the centralized and decentralized systems under the selected economic parameters. Each alternative produces a range of delivered energy costs depending on economic parameters, such as inflation, real interest rate and cost, and the sale price of electricity. A required rate of return of $14 \%$ was used for all compared alternatives.

The comparison of the results presented in Figure 1 and Table 1 suggests that the gas and coal prices along with the size of the thermal energy demand will have a major impact on the cost of the delivered energy for each of the evaluated alternatives. If, for example, the gas price development follows the trends shown in Figure 2, purchase price of electricity follows the trends shown in Figure 3 , and the coal price goes higher than $800 \mathrm{SK} /$ ton, the decentralized heat supply system would be more attractive for a thermal demand less than $350 \mathrm{GJ} /$ year. Higher thermal energy demand and lower coal cost ( $680 \mathrm{SK}$ ) increases the attractiveness of the central heating system. Under the assumed economic parameters, the centralized thermal energy supply system delivers energy at lower cost when the coal price is below $700 \mathrm{SK} /$ ton and the demand exceeds $500 \mathrm{TJ} / \mathrm{year}$.

Under the assumed economic environment, the ranges of delivered energy cost for the three alternatives are overlapping and depend on many variables. Higher real interest rate, coal price, and inflation will result in higher thermal energy cost. The thermal energy cost from the central system with cogeneration will benefit from the purchase price of electricity higher than $1,389 \mathrm{SK} / \mathrm{MWh}$.

Timing and the size of the required investment in the central system alternative will also influence the cost of delivered energy. The total investment of 442.5 million SK assumes that boilers $\mathrm{K} 1$ and $\mathrm{K} 5$ will be replaced in 1997. If the new boiler $\mathrm{K} 1$ is installed in the year 2007 and boiler $\mathrm{K} 5$ is installed in the year 2011, the total required investment in 1997 will increase from 442.5 to 470.5 million SK, thus reducing the cost of the delivered thermal energy.

The economic calculations were performed with the following assumptions: $90 \%$ financing, real interest rate $9.5 \%$, nominal interest rate $17 \%$, coal price $680 \mathrm{SK} /$ ton, gas price $3,350 \mathrm{SK} / \mathrm{m} 3$, electricity purchase price (selling to distribution) 1,389 SK/MWh, electricity cost (buy from distribution) $2,160 \mathrm{SK} / \mathrm{MWh}$, and required return on investment $14 \%$. 


\section{Economic Assumptions}

Coal Cost $=467 \mathrm{Sk} /$ ton to $1275 \mathrm{Sk} / \mathrm{ton}$ Gas Cost $=3.35 \mathrm{sk} / \mathrm{m}^{3}$

Cost of Electricity:

Sale - 1389 Sk'MWh

Purchase -1894 to 3230 Sk/MWh

Financing $=90 \%$

Inflation $=3$ to $18 \%$

Note:

\begin{tabular}{|l|l|}
\hline $\begin{array}{l}\text { Internal rate } \\
\text { of return }\end{array}$ & $14 \%$ \\
\hline
\end{tabular}

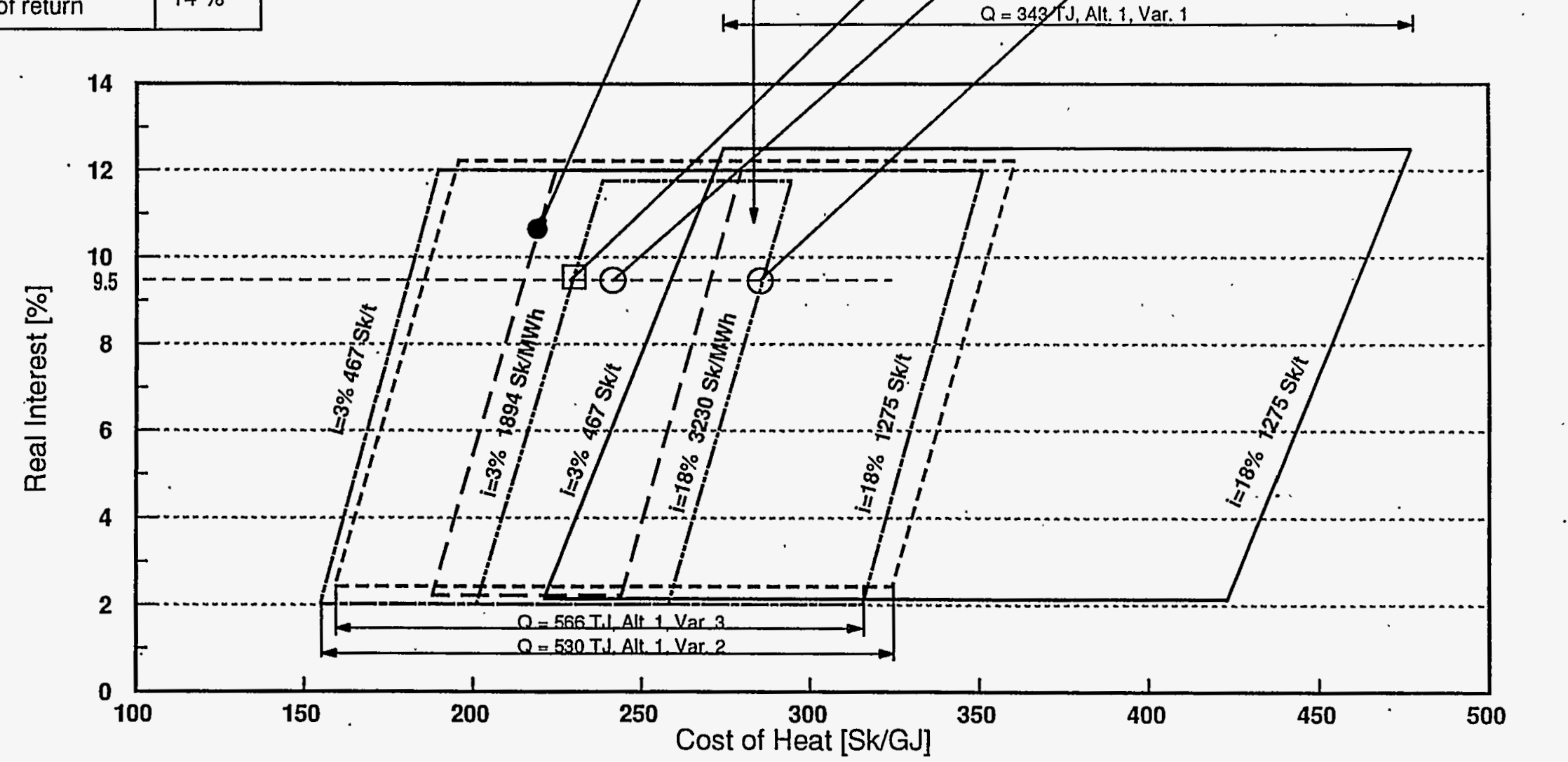

Figure 1 - Economic Analysis and Sensitivity of Results for Decentralized (Alt. 3) and Central (Alt. 1) Production of Thermal Energy for Space and Water Heating in the Town of Handlova, Slovakia

ap11.94km fl Alt. 1, Variant 2, Invest. 300.5 mil. Sk Financing $90.50 \%, i=7.5 \%$

Alt. 1, Variant 2, Invest. 442.5 mil. Sk Financing $90 \%, l=7.5 \%$ Coal Cost $680 \mathrm{Sk} / \mathrm{t}$

Alt. 1, Var. 2, Invest. $300.5+170$ mil. Sk

Coal Cost 680 Stuton

(new boilers after year 2007) 


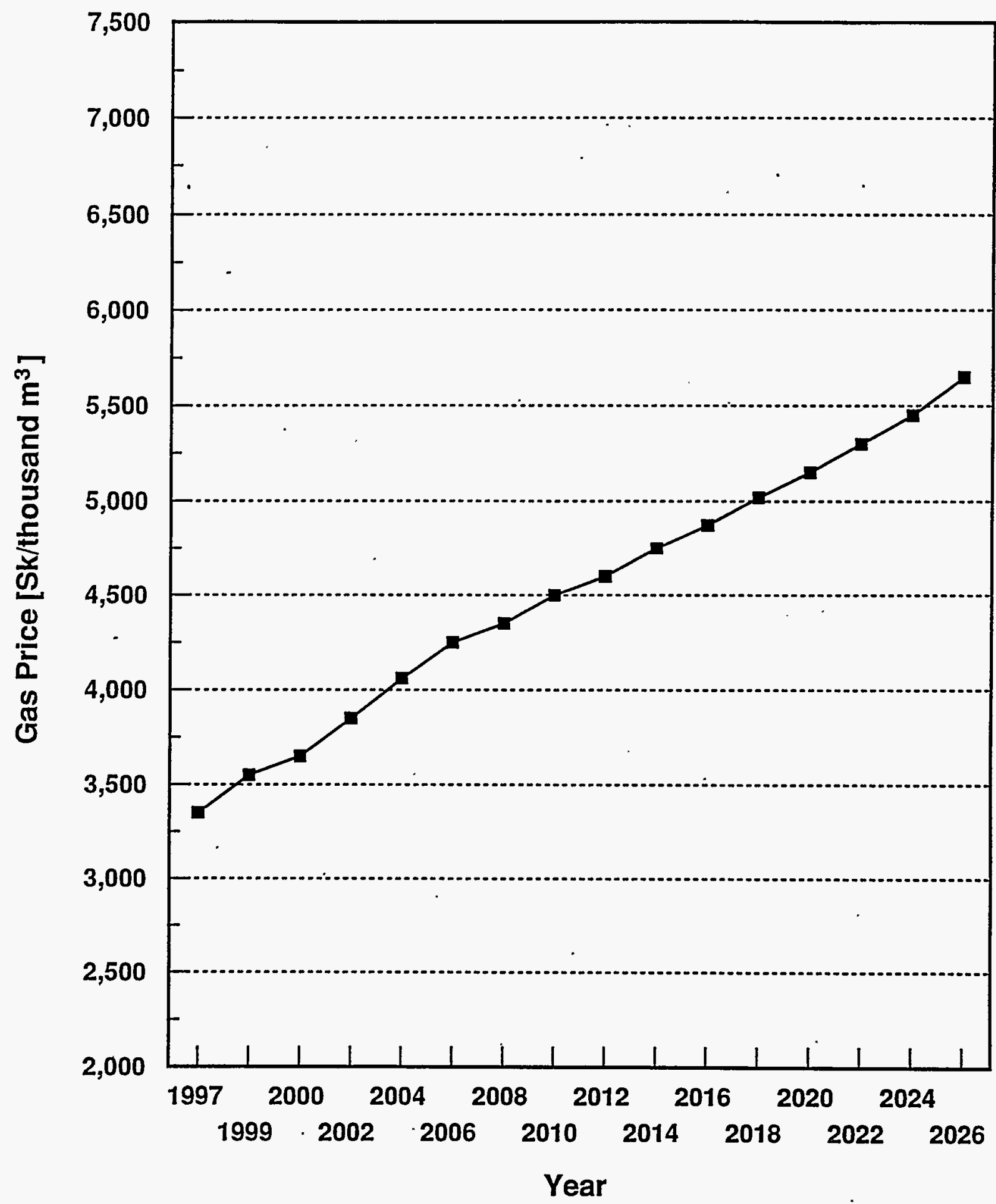

Figure 2 - Natural Gas Prices Development 

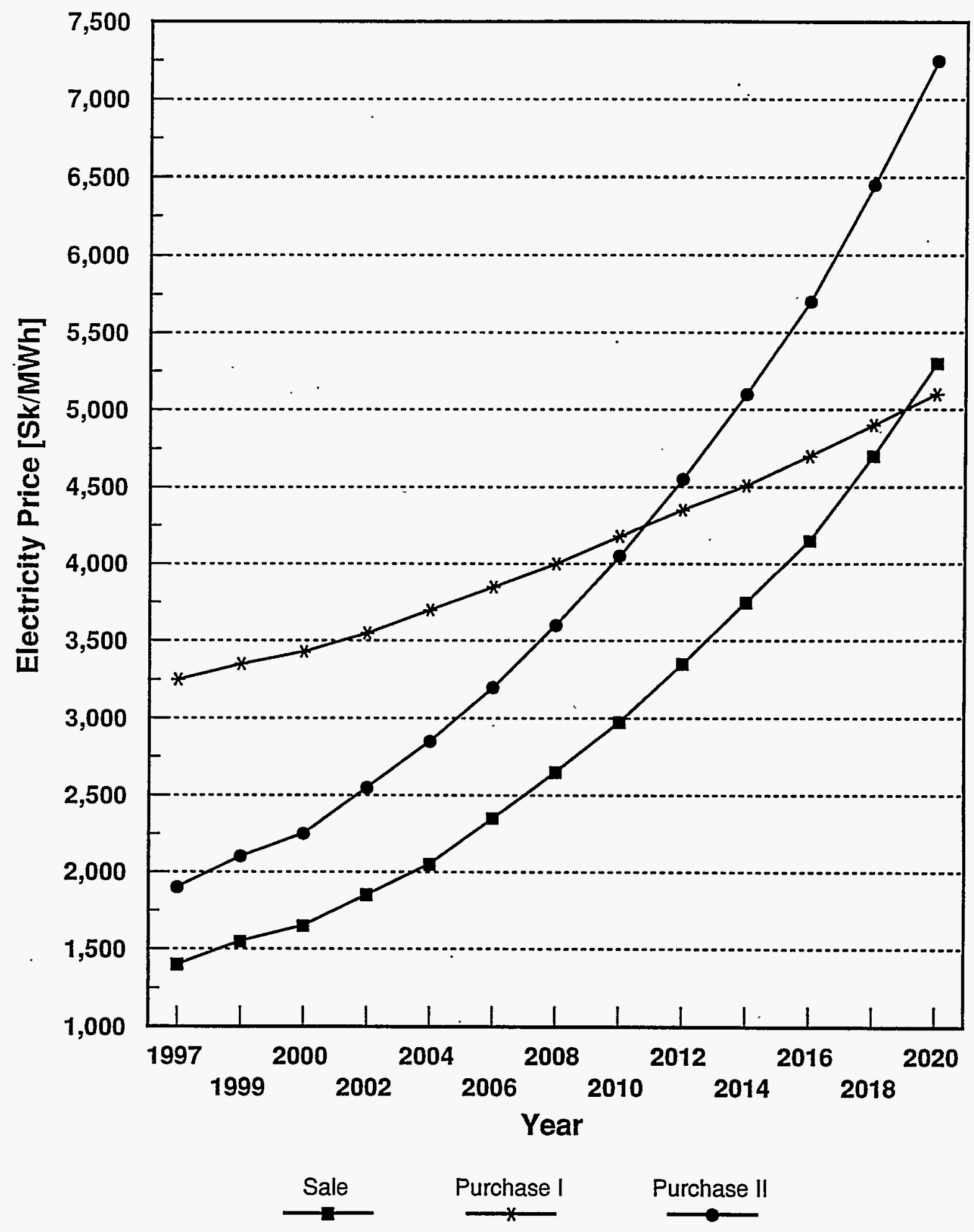

Figure 3 - Electricity Prices Development 


\section{INTRODUCTION}

\subsection{SCOPE AND APPROACH}

The purpose of this study is to support the town officials in Handlova, Slovakia in their effort to provide a thermal energy source for space heating and water heating for all the demand sectors of the town by providing necessary technical and economical information about available alternative solutions.

The study performs analyses of alternative solutions of heat supply available for the Town of Handlova and evaluates their technical, economical and environmental merits. It analyzes the alternatives with the respect to the cost of delivered thermal energy to the user. This study utilizes results of previous studies and other projects performed in 1992 and 1993, and all available measurements performed by the Heating Plant and by the users.

\subsection{REPORT ORGANIZATION}

This report is organized into five chapters. Chapter 1 is an introduction and provides information on the subject of the project, methodology used, report organization and study participants. Chapter 2 provides information on the current state of the energy supply and demand in Handlova and the physical condition of the existing district heating system. It also describes the current thermal energy demand for space heating and water heating purposes and presents three possible development scenarios. Chapter 3 contains an economic analysis of the central heating system, which also cogenerates electricity, and provides an analysis of the sensitivity of the delivered energy cost to the input parameters. The analysis of the decentralized natural gas distributed boiler-based energy system are presented in the Chapter 4. Chapters 3 and 4 are significant chapters of this report. Chapter 5 provides a statistical summary of the results of the evaluation of the three energy supply alternatives that were analyzed.

\subsection{STUDY PARTICIPANTS}

This project was made possible by the US Agency for International Development (US AID). US AID provided funding through the Department of Energy, Office of Energy Efficiency and Renewable Energy, which contracted Battelle, Pacific Northwest Laboratories (PNL) to manage and technically direct the project. The analyses of the demand side and the supply side were performed by the Energy Research Institute (EGU), Bratislava and by the US based company Tecogen. The role of the US partners was to participate in an advisory role, to perform an analysis related to the demand side and to manage the project activities: 
EGU Bratislava contracted with the Slovak company Stavimex, with the Building Administration Company (Bytovy Podnik Mesta Handlova - BPMH) and with the Town Administration Office. Stavimex was responsible for providing analysis of the decentralized heating system, and BPMH and the Town were responsible for providing information on residential and non-residential building stock and thermal energy consumption for space and water heating. 


\section{THE SUPPLY AND DEMAND SIDE ANALYSES}

This chapter develops and evaluates the supply side alternatives for production and distribution of thermal energy for space heating and water heating. The investment effectiveness and the sensitivity analysis are performed for each of the three developed alternatives. Variables in the sensitivity study are demand side energy consumption levels, real interest on borrowed money and cost of fuels.

The purpose of the work presented in this chapter is to provide information on technical, economic and environmental parameters for each of the thermal energy supply alternatives. Section 2.1 describes the history and current state of the thermal energy supply. Section 2.2 summarizes the existing energy demand for space and water heating by sector, fuel and type of equipment. It also provides information on availability of fuels. Section 2.3 develops scenarios of expected future energy demand.

\subsection{HISTORY AND CURRENT STATE OF THE THERMAL ENERGY SUPPLY AND DEMAND}

The central heating system covers $80 \%$ of the current energy demand for space heating and water heating in the town of Handlova. The Heating Plant was built from 1937 to 1940 and was originally designed as a cogeneration plant with a condensing steam turbine, which supplied the electricity for the coal mine Handlova. Operation of the plant began in 1938. The last major investment to the plant was in 1954 , when the boiler $\mathrm{K} 6\left(45 \mathrm{t} / \mathrm{h}, 432^{\circ} \mathrm{C}, 3.8 \mathrm{MPa}\right)$ was built.

The fuel used by the Heating Plant is a brown coal dust with a heating value of $12.54 \mathrm{MJ} / \mathrm{kg}$. The Heating Plant is equipped with a closed loop condenser cooling system, natural circulation boilers, a closed loop coal preparation and delivery system and mechanical ash collectors. The plant had the following parameters:

Total installed boiler output

Total output of turbo-generators

Number of boilers

Number of turbo-generators
195 ton/hr

$30 \mathrm{MWe}$

4

3

The steam distribution system was built in 1965 and the central heating system was started in 1968. Steam was supplied through the non-regulated heat transfer station TG2 at 3.0/0.9 MPa and $250^{\circ} \mathrm{C}$. Currently, the distribution network consists of 29 heat exchanger stations, 5,300 meters of pipes installed in non-accessible channels and 2,735 meters of pipes on the surface. Maximum pipe dimension is DN 400 for the steam distribution lines and DN 150 for the condensate return lines. 
Due to equipment age and economically ineffective production of electricity, the cogeneration plant was converted to heat production only. Boiler K1 was retrofitted in 1982 and boiler K5 was retrofitted and equipped with a pre-combustion reactor in 1990. Boiler K6, which was installed in 1954 was upgraded in 1989 and was converted to gas operation.

The heat generating plant uses industrial grade coal (brown coal dust) with a heating value of $8.5-12.54 \mathrm{MJ} / \mathrm{kg}$ and natural gas with a heating value of $33.4 \mathrm{MJ} / \mathrm{m3}$. Boilers with natural circulation are equipped with closed-loop coal feed and electrostatic filters. Boiler $\mathrm{K} 1$ is equipped with a pre-combustion reactor, boilers $K 5$ and $K 6$ are equipped with gas burners with capacity equal to $50 \%$ of the boiler total output. Total output of all boilers is $100 \mathrm{ton} / \mathrm{hr}(60 \mathrm{MWt})$. The plant employs 120 workers and 24 administration staff members.

The new, 115 meter concrete stack was built in 1983; in 1984 and 1985 the flue exhaust was equipped with electrostatic filters. The old generators were removed from the building. Ash produced by the heating plant is either used by the coal mine to fill old coal mine cavities or partially deposited to ash and coal mine refuse depository outside of town.

In general, the central heating system, including the heat generating plant, distribution and the heat exchanging stations is old and inefficient.

\subsection{BASELINE PARAMETERS}

\subsubsection{Energy use baseline and demand forecast}

Energy consumption in Handlova for space heating, water heating and for industrial processes in 1992 is summarized in Table 2.1.

Nearly $62 \%$ of the net delivered energy (fuel input less losses in conversion and transit) is consumed by the residential sector. More detailed energy consumption data are presented in the Demand Side Analysis Report, which is part of this study. Industrial consumption represents about $19 \%$ and the non-residential sector also represents about $19 \%$. District heat-is the major energy source for space and water heating, representing $79.6 \%$ of the total energy consumption.

The Industrial Sector in Handlova uses the District Heating System exclusively as a source of thermal energy for space and water heating. Table 2.2 below shows the industrial energy users and the amount of energy they consume. The thermal energy use for industrial processes is negligible. 
Table 2.1 - Energy End Use by Sectors and Fuels (GJ), 1992

\begin{tabular}{|c|c|c|c|c|c|}
\hline \multirow{2}{*}{$\begin{array}{l}\text { की } \\
\text { FUEL } \\
\text { R }\end{array}$} & \multicolumn{3}{|c|}{ 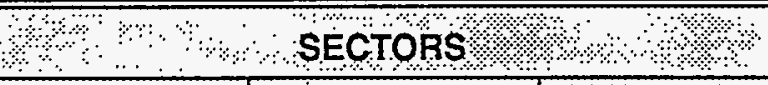 } & \multicolumn{2}{|c|}{ १ TOTAL } \\
\hline & $\begin{array}{l}\text { Residential } \\
\end{array}$ & $\begin{array}{l}\text { Nonn } \\
\text { Residentlal }\end{array}$ & Industrall & [GJ/Year $]$ & f\% \\
\hline $\begin{array}{l}\text { LOCAL: } \\
\text { Coal } \\
\text { Gas } \\
\text { Electr. }\end{array}$ & $\begin{array}{r}29,599 \\
66,950 \\
1,200\end{array}$ & $\begin{array}{r}0 \\
50 \\
1,684\end{array}$ & $\begin{array}{l}0 \\
0 \\
0\end{array}$ & $\begin{array}{r}29,599 \\
67,000 \\
2,884\end{array}$ & $\begin{array}{r}5.2 \\
11.9 \\
0.5\end{array}$ \\
\hline $\begin{array}{l}\text { BOILER HOUSES: } \\
\text { Coal } \\
\text { Gas }\end{array}$ & $\begin{array}{l}0 \\
0\end{array}$ & $\begin{array}{r}11,080 \\
4,737\end{array}$ & $\begin{array}{l}0 \\
0\end{array}$ & $\begin{array}{r}11,080 \\
4,737\end{array}$ & $\begin{array}{l}2.0 \\
0.8\end{array}$ \\
\hline DISTRICT HEAT & 251,033 & 92,054 & 107,671 & 450,758 & 79.6 \\
\hline TOTAL & 348,782 & $1 / 4109,605$ & 107,671 & $2.566,058$ & 100 \\
\hline$[\%]$ & क्ष 6 & ২ै। 19.4 & \% $19: 0$ & 100 & 100 \\
\hline
\end{tabular}

Table 2.2 - Industrial User Energy Consumption (GJ), 1992

\begin{tabular}{|c|c|c|}
\hline \multirow{2}{*}{ औै USER Pै। } & \multicolumn{2}{|c|}{ DISTRICT HEAT } \\
\hline & IGJ/Yearf: & {$[\%] \%$} \\
\hline Coal Mine & 76,736 & 71.3 \\
\hline Chemika & 5,684 & 5.2 \\
\hline Lahke Konstrukcie & 19,177 & 17.8 \\
\hline Slovenka & 2,114 & 2.0 \\
\hline AMK & 188 & 0.2 \\
\hline CSD Station & 2,079 & 1.9 \\
\hline State Farm & 1,693 & 1.6 \\
\hline ITOTAL & 10767 & $\therefore 100$ \\
\hline
\end{tabular}

\subsubsection{Demand Forecast}

This section develops the three variants for energy demand growth used for the study. Assuming a 25 year life for the heat supply equipment to be built by 1997 , the energy demand was projected to the year 2022. 


\section{Load Variant 1:}

This variant assumes no change in the thermal energy demand in the Residential and NonResidential Sectors and assumes detachment of the industrial sector from the District Heating System.

Under this variant, energy demand will remain on the 1992 level of 458,387 GJ/Year for space heating and water heating in Residential and in Non-Residential sectors. The Industrial Sector will be served by its own sources, but the annual consumption would remain the same - 107,671 GJ/Year. This variant represents the lowest possible energy demand, when only the buildings owned by the town would be served by the central heating system.

\section{Load Variant 2:}

This variant based on the Urban Development Plan for the Town of Handlova performed by AGS Atelier for the Town Hall in 1993. This study predicted the town population would increase from 18,332 in 1992 to 19,500 in the year 2010. By extrapolating the growth curve at a somewhat cautious rate, the town population was predicted to be 19,750 in 2022 . This is a population increase of approximately 1400 persons, or $5.22 \%$. Industrial activity in this variant was assumed to stay at . the 1992 level with no increase in thermal energy demand.

Under these assumptions, energy demand for space heating and water heating would increase by 18,206 [GJ], or $3.22 \%$ of the town energy demand in 1992. Increase in District Heating Demand is assumed $11,268 \mathrm{GJ}$, or $4.5 \%$.

\section{Load Variant 3:}

This variant assumed greater population growth and increased industrial activity. Population growth was assumed $6 \%$ greater than predicted in Scenario 1 , for a total increase of $11.22 \%$ or 2057 persons. Industrial thermal energy demand was assumed to grow by $20 \%$ from the 1992 level.

For this variant, energy demand for residential space heating and water heating would increase by $39,133 \mathrm{GJ}$, or $6.91 \%$, and industrial thermal energy demand would increase by 21,534 GJ, or $3.80 \%$. Total energy demand would increase by $60,667 \mathrm{GJ}$, or $10.71 \%$ of the total demand in 1992. The district heating demand would increase by 24,247 GJ $(4.28 \%)$ due to population growth, and 23,287 GJ (4.11\%) due to industrial growth.

The summary of parameters in each variant is presented in Table 2.3. 
Table 2.3 Demand Forecast Scenarios, Year 2022

\begin{tabular}{|c|c|c|c|c|c|c|}
\hline$\because \cdots$ & Koad & trant & Had & artant 2 & Load & fariant 3 \\
\hline $\mathbf{G J / y r}: \quad \therefore$ & MWt & GJlyr & MWL & G/lyr & MWi & GJ/yr \\
\hline Residential Sector & 30.32 & 251,033 & 30.32 & 251,033 & 30.32 & 251,033 \\
\hline Population Growth & -- & -- & 1.58 & 11,268 & 3.40 & 24,247 \\
\hline Non-Residential Sector & 11.12 & 92,054 & 11.12 & 92,054 & 11.12 & 92,054 \\
\hline $\begin{array}{l}\text { New Customers } \\
\text { (Residential and Non-Residential) }\end{array}$ & -- & -- & 8.2 & 68,024 & 8.20 & 68,024 \\
\hline Industry & --- & --- & 12.80 & 107,671 & 12.8 & 107,671 \\
\hline Industrial Growth & -- & --- & -.- & --- & 2.56 & 23,287 \\
\hline$\therefore \quad \therefore \quad$ ATOTAL & 44.44 & 343087 & 6402 & 530,050 & 6840 & 566,316 \\
\hline
\end{tabular}

\subsubsection{Fuel Availability}

The State Upper Nitra Coal Mines (Hornonitrianske Bane) with headquarters in Prievidza, Slovakia have, in their letter from August 14, 1993 to SEP Bratislava, guaranteed supply of standard quality coal up to year 2020 .

The following coal quality was guaranteed:

$\begin{array}{ll}\text { Heating value } & \mathrm{Qa}=10.5 \mathrm{MJ} / \mathrm{kg} \\ \text { Ash content } & \mathrm{A}=36.38 \% \\ \text { Water } & \mathrm{W}=21.46 \% \\ \text { Sulfur } & \mathrm{S}=1.55 \% \\ \text { Carbon } & \mathrm{C}=66.51 \% \\ \text { Hydrogen } & \mathrm{H}=5.4 \% \\ \text { Nitrogen } & \mathrm{N}=1.28 \% \\ \text { Oxygen } & \mathrm{O}=25.49 \%\end{array}$

The Slovak Gas Company (Slovensky Plynarensky Podnik), the local gas utility, with headquarters in Prievidza, Slovakia is capable and willing to provide a sufficient gas supply to satisfy the needs of the Town of Handlova. Currently, the low pressure gas distribution network in Handlova is in use and serves only small users (residences). The decentralized heating system would require installation of new pipes with a gas pressure of $0.3 \mathrm{MPa}$ to serve new, distributed boilers. 


\section{CENTRAL DISTRICT HEATING SYSTEM}

This chapter presents a technical and economic evaluation of the central district heating system alternatives considered for the thermal energy supply for the town of Handlova. Section 3.1 presents the analysis of a hot water based distribution system. The investments required for buried, pre-insulated pipes and for pipes installed in a channel are also shown. Section 3.2 presents the analysis of Alternative 1 for the central heating system with cogeneration and with a coal/gas combined fuel base. Section 3.3 presents the analysis of Alternative 2 for the central heating system with cogeneration based on coal only.

\section{1 · DISTRIBUTION SYSTEM ANALYSIS}

The replacement of the old steam distribution system with a new, hot water distribution system must be performed without service interuption. Therefore, the new system will be installed parallel to existing one, as recommended by the study "Transition from Steam to Hot Water Distribution System in Town of Handlova", which was performed by Energoprojekt Kosice in March 1992. The replacement of heat exchangers in all stations is assumed to be performed in the summer season.

The analysis of the distribution system was based on the system layout shown in Figure 3.1. It includes hydraulic calculations of the system and estimates of required investment for two scenarios. One assumes use of buried pre-insulated pipes, the other assumes use of pre-insulated pipes installed in utility channels. The hydraulic calculation of the hot water distribution system was performed for two scenarios. One assumed a central pumping station only; the other assumed the use of an additional pumping station for winter peak operation in critical locations, as determined by the system pressure diagram.

\subsubsection{Distribution System with Central Pumping Station Only}

The analyses were performed with the assumptions that the distribution system will be designed as a two-pipe system with pressure independent heat exchanger stations, with a central pumping station located in the central heating plant building and with a system temperature gradient of $130 / 70^{\circ} \mathrm{C}$.

The pressure diagram of such system is shown in Figure 3.2. The specification of the pipes required for this system follow. 


\begin{tabular}{|c|c|c|c|}
\hline Pipe Dimension & Item: & Alternative $\mathrm{A}$ & Alternative $\mathrm{B}$ \\
\hline DN 50 & $\begin{array}{l}\text { Total length [m] } \\
\text { T fittings [pcs] } \\
\text { Elbows [pcs] } \\
\text { Compensators [pcs] }\end{array}$ & $\begin{array}{c}3,530 \\
6 \\
54 \\
68\end{array}$ & $\begin{array}{c}4,230 \\
4 \\
70 \\
60\end{array}$ \\
\hline DN 65 & $\begin{array}{l}\text { Total length [m] } \\
\text { Elbow [pcs] } \\
\text { Compensator [pcs] }\end{array}$ & $\begin{array}{c}160 \\
6 \\
4\end{array}$ & $\begin{array}{c}160 \\
6 \\
4\end{array}$ \\
\hline DN 80 & $\begin{array}{l}\text { Total length [m] } \\
\text { T fitting } 80 / 80 \text { [pcs] } \\
\text { T fitting } 80 / 50 \text { [pcs] } \\
\text { Reduction } 80 / 50 \text { [pcs] } \\
\text { Elbow [pcs] } \\
\text { Compensator [pcs] }\end{array}$ & $\begin{array}{c}1,140 \\
-- \\
2 \\
-- \\
26 \\
28\end{array}$ & $\begin{array}{c}2,670 \\
4 \\
4 \\
2 \\
30 \\
52\end{array}$ \\
\hline DN 100 & $\begin{array}{l}\text { Total length [m] } \\
\text { Elbow [pcs] } \\
\text { Compensator [pcs] }\end{array}$ & $\begin{array}{c}590 \\
8 \\
12\end{array}$ & $\begin{array}{l}590 \\
12 \\
12\end{array}$ \\
\hline DN 150 & $\begin{array}{l}\text { Total length [m] } \\
\text { T fitting 150/150 [pcs] } \\
\text { T fitting } 150 / 100 \text { [pcs] } \\
T \text { fitting } 150 / 80[\mathrm{pcs}] \\
\text { T fitting } 150 / 50 \text { [pcs] } \\
\text { Reduction } 150 / 100 \text { [pcs] } \\
\text { Reduction } 150 / 80 \text { [pcs] } \\
\text { Reduction } 150 / 50 \text { [pcs] } \\
\text { Elbow [pcs] } \\
\text { Compensator [pcs] }\end{array}$ & $\begin{array}{c}7,530 \\
4 \\
2 \\
6 \\
6 \\
2 \\
6 \\
6 \\
82 \\
100\end{array}$ & $\begin{array}{c}5,690 \\
2 \\
4 \\
4 \\
8 \\
- \\
4 \\
- \\
64 \\
80\end{array}$ \\
\hline DN 200 & $\begin{array}{l}\text { Total length [m] } \\
\text { T fitting } 200 / 200 \text { [pcs] } \\
T \text { fitting } 200 / 150 \text { [pcs] } \\
T \text { fitting } 200 / 100 \text { [pcs] } \\
T \text { fitting } 200 / 50 \text { [pcs] } \\
\text { Reduction } 200 / 150 \text { [pcs] } \\
\text { Reduction } 200 / 100 \text { [pcs] } \\
\text { Elbow [pcs] } \\
\text { Compensator [pcs] }\end{array}$ & $\begin{array}{c}3,700 \\
2 \\
2 \\
2 \\
14 \\
2 \\
2 \\
72 \\
50\end{array}$ & $\begin{array}{c}3,580 \\
- \\
- \\
4 \\
16 \\
4 \\
- \\
38 \\
50\end{array}$ \\
\hline DN 250 & $\begin{array}{l}\text { Total length [m] } \\
\text { T fitting } 250 / 200 \text { [pcs] } \\
T \text { fitting } 250 / 150 \text { [pcs] } \\
T \text { fitting } 250 / 80 \text { [pcs] } \\
T \text { fitting } 250 / 50 \text { [pcs] } \\
\text { Reduction } 250 / 200 \text { [pcs] } \\
\text { Elbow [pcs] } \\
\text { Compensator [pcs] }\end{array}$ & $\begin{array}{c}1,720 \\
2 \\
- \\
2 \\
4 \\
2 \\
16 \\
30\end{array}$ & $\begin{array}{c}1,720 \\
2 \\
2 \\
2 \\
2 \\
2 \\
16 \\
30\end{array}$ \\
\hline
\end{tabular}




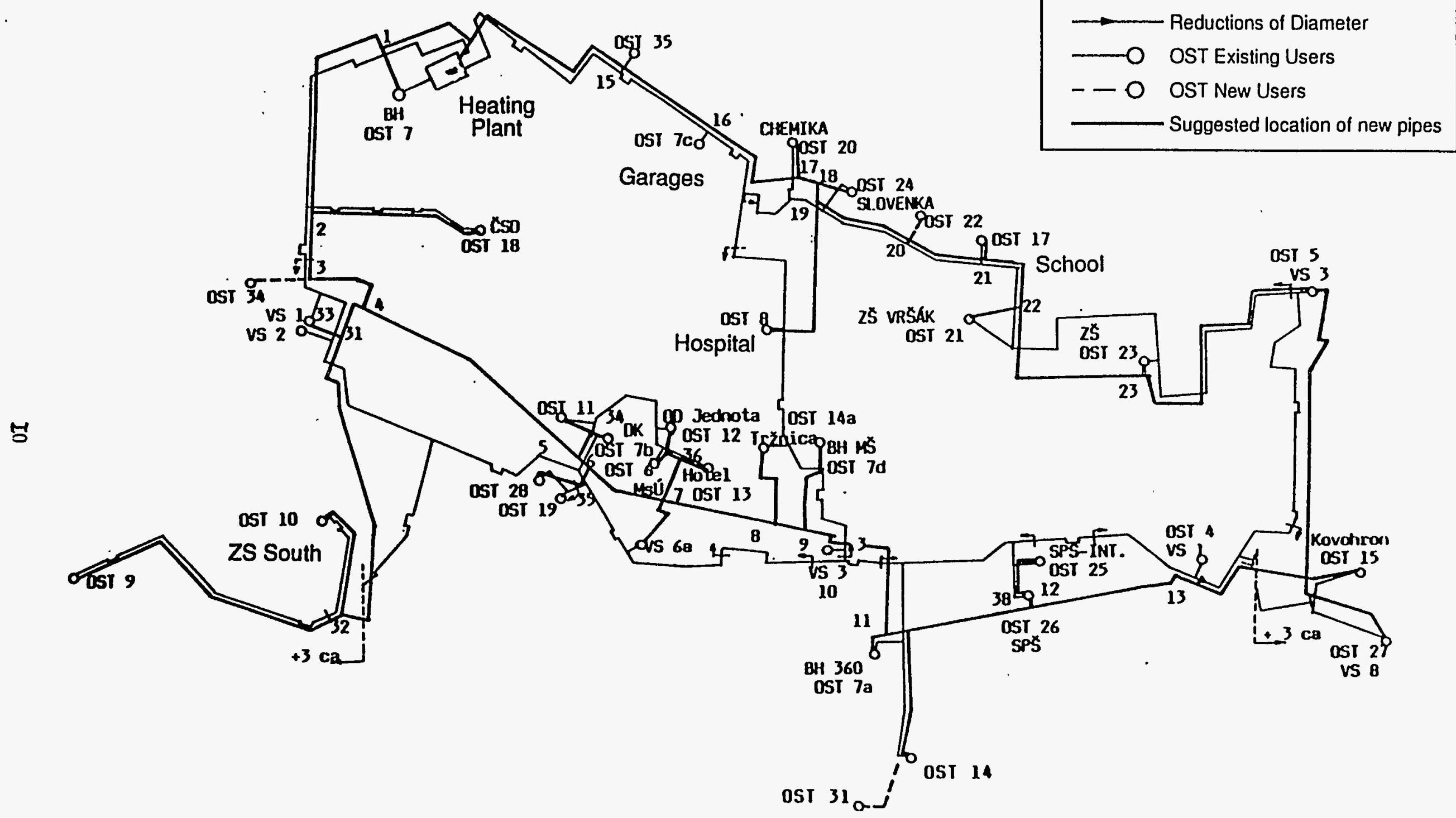

Figure 3.1 - Layout of Central Heating System in Town of Handlova 
Quotes for delivery of the materials listed were requested and received from PIPECO, Ltd. Podbrezova and the ASEA Brown Boveri Bratislava. Pricing information from BTV STAV-ISOLAR Bratislava was also used for comparison. This company is offering pre-insulated pipes type FotavIsoplus and also type KE Rohrsystem und Umwelttechnik GmBh. For the purpose of this study, an average price was calculated for each component from all received quotes.

The cost of installation was calculated based on information provided by the company ALDY, s.r.o: and on information included in the previously mentioned study "Transition from Steam to Hot Water Distribution System in Town of Handlova", which was performed by Energoprojekt Kosice in March 1992.

- The cost of material and installation of pre-insulated pipes buried in-ground.

\begin{tabular}{ll}
$\begin{array}{l}\text { Material } \\
\text { Installation }\end{array}$ & $\begin{array}{l}45,000,000 \mathrm{SK} \\
21,000,000 \mathrm{SK}\end{array}$ \\
\hline Total & $66,000,000 \mathrm{SK}$
\end{tabular}

- The cost of material and installation of standard pipes installed in prefabricated utility channels

\begin{tabular}{ll}
$\begin{array}{l}\text { Material } \\
\text { Installation }\end{array}$ & $\begin{array}{l}25,000,000 \text { SK } \\
91,000,000 \text { SK }\end{array}$ \\
\hline Total & $116,000,000$ SK
\end{tabular}

Based on this comparison, the economic analysis of the central district system was performed assuming the hot water distribution system with pre-insulated, directly buried pipes (Alternative A).

The system arrangement with the central pumping station will require only $550 \mathrm{MWh}$ of electric energy consumption to operate the pumps.

\subsubsection{Distribution System with Central Pumping Station and an Additional Pumping Station for Peak Operation}

In this alternative, the central pumping station is located in the heating plant and an additional pumping station is located on distribution branch 4-31 (see Figure 3.1) Distribution is designed with a two-pipe arrangement with pressure independent heat exchanger stations. Temperature gradient is $130 / 70^{\circ} \mathrm{C}$. The pressure diagram is shown in Figure 3.3. 


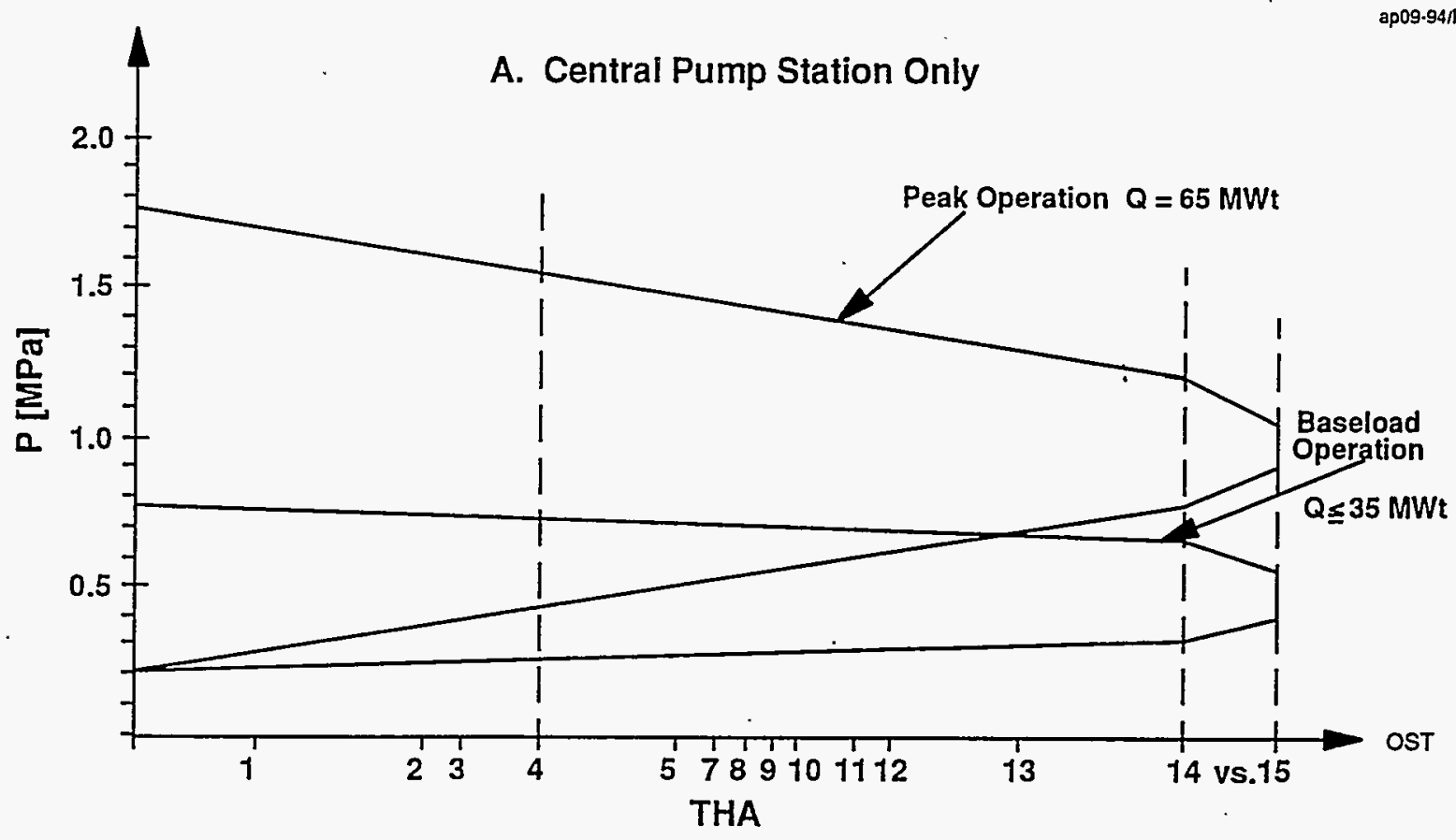

Figure 3.2 - Pressure Diagram of Main Distribution System

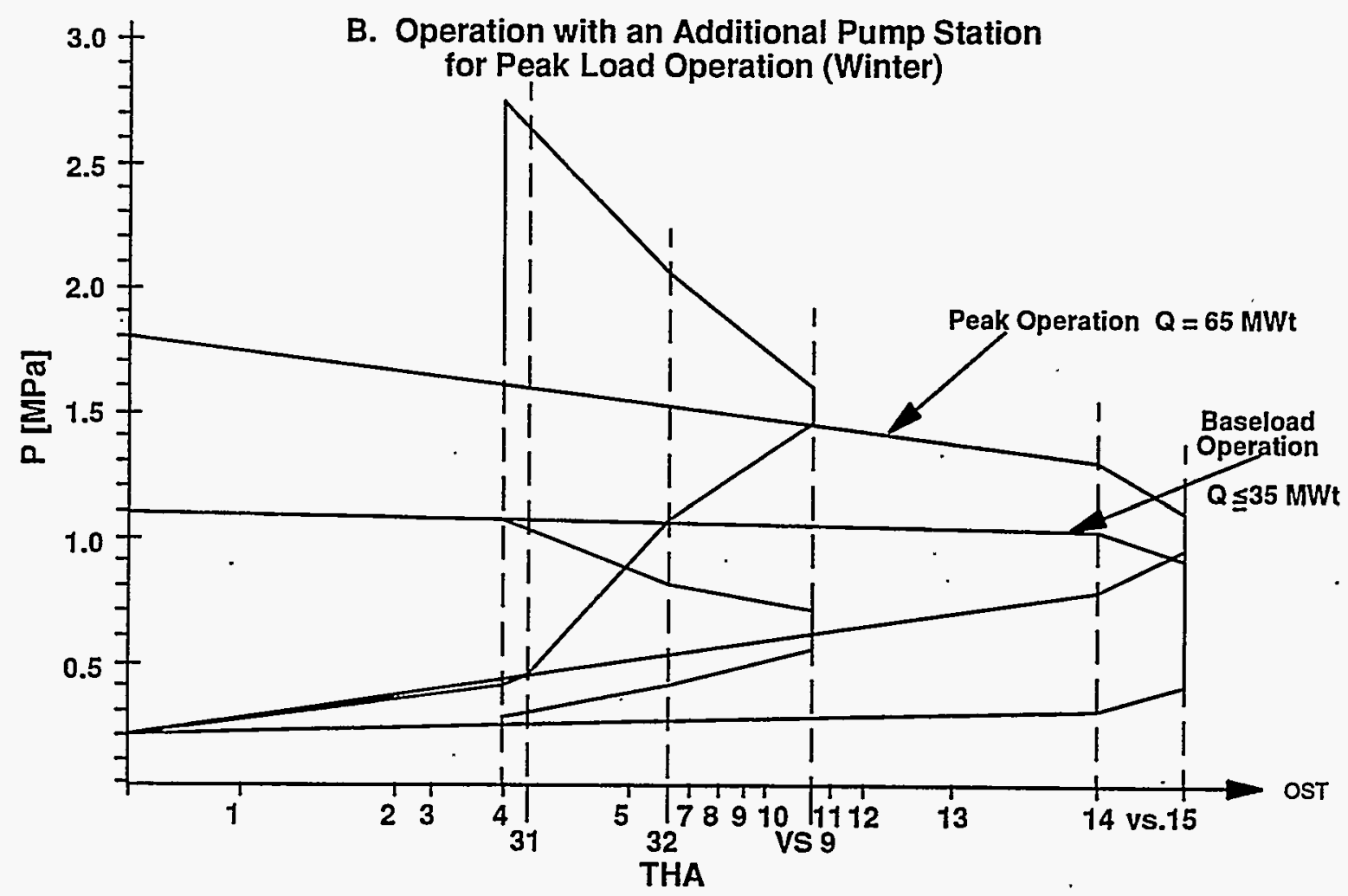

Figure 3.3 - Pressure Diagram of Main Distribution System 
The specification of pipes and other components is shown as Alternative B in Section 3.1.1. The cost of material and installation is approximately $5 \%$ lower for this alternative. The cost of additional peak pumps, the cost of a remote control system for the station and an additional electricity consumption cost - approximately $750 \mathrm{MWh}$ - will eliminate this cost advantage and will bring the total cost to the same level as for Alternative $A$.

\subsubsection{Heat Exchanger Stations}

The new heat exchangers and other required equipment will be installed in existing buildings. The domestic water heating equipment is assumed to be installed at the consumption sites - in the building basements. A secondary side distribution will be utilized for providing the heat source for water heating purposes.

The installed cost of compact water-to-water heat exchangers from company Tlakove Nadoby, Zilina, should be expected to be 80,000 thousand SK. The installed cost of plate heat exchangers form company ALFA LAVAL can be expected to be 54,000 thousand SK. This lower price was used for the economic evaluation calculations.

\subsection{ALTERNATIVE 1 : CENTRAL DISTRICT HEATING SYSTEM WITH COGENERATION AND COAL/GAS FUELS}

This alternative assumes reconstruction of existing boilers $K 5$ and $K 6$, fuel supply equipment, ash removal equipment and hot water manifolds; completion of a new chemical plant for water treatment; installation of new gas fired hot water boilers including gas piping, new $6.2 \mathrm{~kW}$ electrical distribution center, new mechanical room, new hot water heat exchanger station, and limestone preparation equipment; and a new ash dump site. General schematic of the system is shown in Figure 3.4. The plant location is shown in Figure 3.5.

\subsubsection{Equipment Specification:}

Boiler K1 - steam boiler made by "Pruni Brnenska Strojirna", retrofitted in 1982 (up-stream combustion reactor addition)

$\begin{array}{ll}\text { Max. boiler output } & 30 \mathrm{MWt} \\ \text { Max. mass flow } & 35 \mathrm{t} / \mathrm{hr} \\ \text { Nominal steam pressure } & 3.6 \mathrm{MPa} \\ \text { Nominal steam temperature } & 425^{\circ} \mathrm{C} \\ \text { Nominal water temperature } & 110^{\circ} \mathrm{C} \\ \text { Thermal efficiency } & 77 \% \\ \text { Fuel } & \text { brown coal }\end{array}$

Note: Reconstruction of this boiler - installation of the up-stream reactor -was already performed 


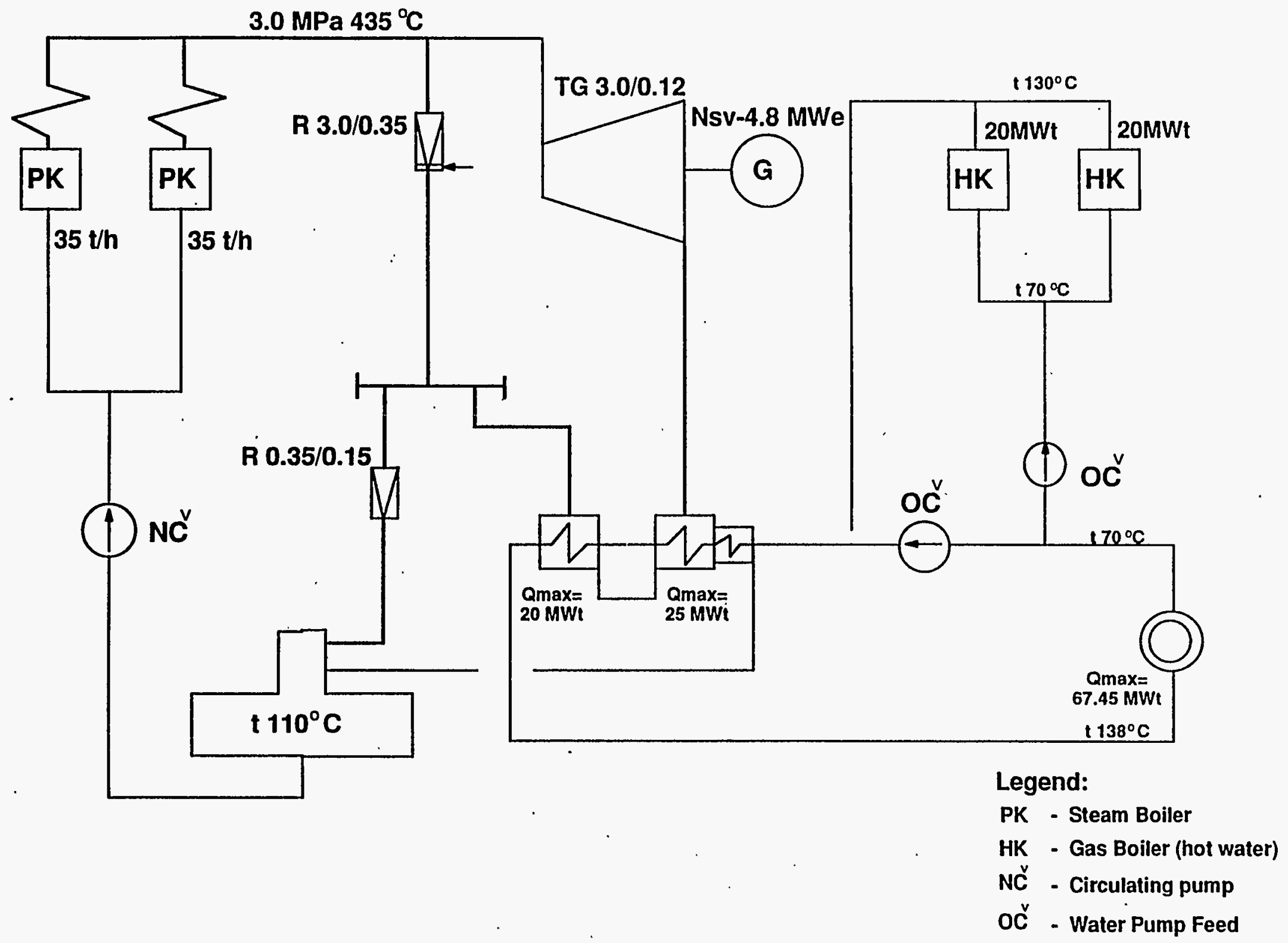

Figure 3.4 - Basic Equipment Diagram for Alternative 1 


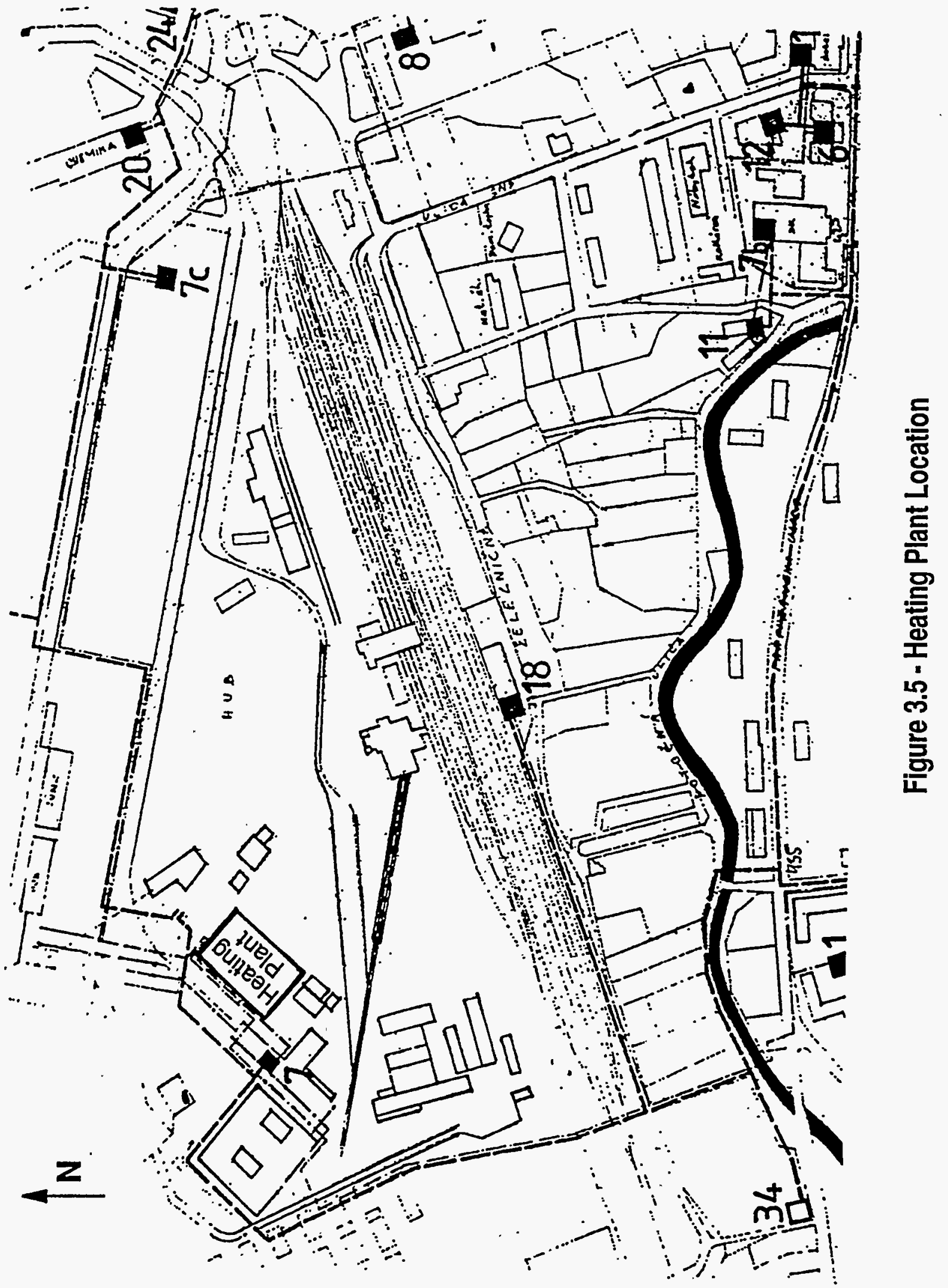


Boiler K5 - steam boiler made by "Prvni Brnenska Strojirna". Recommended reconstruction and installation of up-stream combustion reactor in 1995.
Max. boiler output
Max. mass flow
$30 \mathrm{MWt}$
Nominal sieam pressure
Nominal steam temperature
$35 \mathrm{t} / \mathrm{hr}$
Nominal water temperature
Thermal efficiency
3.6 $\mathrm{MPa}$
$425^{\circ} \mathrm{C}$
$110^{\circ} \mathrm{C}$
$77 \%$
Fuel
brown coal

Note : this boiler will be retrofitted and equipped with up-stream combustion reactor.

Boiler HK1 - gas fired hot water boiler to be built in 1996, manufacturer SES TImace or DjDj- Wanson.
Max. boiler output
$20 \mathrm{MWt}$
Nominal water pressure
$3.2 \mathrm{MPa}$
Nominal inlet water temperature
$70^{\circ} \mathrm{C}$
Nominal outlet water temperature
$130^{\circ} \mathrm{C}$
Thermal efficiency
$94 \%$
Fuel
Natural gas, $33.4 \mathrm{MJ} / \mathrm{m} 3$

The gas burner for inlet gas pressure of 0.1-0.3 MPa, recirculation pump, M\&R system, EGA analyzer and all electrical equipment will be included with the boiler.

Boiler HK2 - gas fired hot water boiler to be built in 1997, manufacturer SES TImace or DjDj- Wanson.
Max. boiler output
Nominal water pressure
$20 \mathrm{MWt}$
Nominal inlet water temperature
$3.2 \mathrm{MPa}$
Nominal outlet water temperature
$70^{\circ} \mathrm{C}$
$130^{\circ} \mathrm{C}$
Thermal efficiency
$94 \%$
Fuel
Natural gas, $33.4 \mathrm{MJ} / \mathrm{m} 3$

The gas burner for inlet gas pressure $0.1-0.3 \mathrm{MPa}$, recirculation pump, M\&R system, EGA analyzer and all electrical equipment will be included with the boiler. 
TG1 - 4.8 MWe back-pressure steam turbine made by "Prvni Brnenska Strojirna"

$\begin{array}{ll}\text { Nominal electrical output } & 4.8 \mathrm{MWe} \\ \text { Nominal steam throughput } & 40 \mathrm{t} / \mathrm{hr} \\ \text { Nominal steam parameters: } & \\ \text { • pressure } & 3.2 \mathrm{MPa} \\ \text { - temperature } & 420^{\circ} \mathrm{C} \\ \text { Back-pressure turndown } & .035-.35 \mathrm{MPa} \\ & \\ \text { Generator: } & \\ \text { - Nominal RPM } & 3,0001 / \mathrm{min} \\ \text { - Nominal Power Output } & .6,000 \mathrm{kVA} \\ \text { - Voltage } & 6.3 \mathrm{kV} \\ \text { - Frequency } & 50 \mathrm{~Hz}\end{array}$

The turbine package includes control and safety equipment, lubrication package, leakage steam condensation package and piping.

Heat Transfer Station including circulation pumps

1 piece of tube and shell steam-to-water heat exchanger

$\begin{array}{lr}\text { Nominal thermal output } & 25,0 \mathrm{MWt} \\ \text { Nominal water parameters } & 60 / 94^{\circ} \mathrm{C} \\ \text { Nominal steam parameters } & \\ \text { • pressure } & .12 \mathrm{MPa} \\ \text { - temperature } & 105^{\circ} \mathrm{C} \\ \text { Design pressure } & \mathrm{PN} 25\end{array}$

1 piece of tube and shell steam-to-water heat exchanger

$\begin{array}{lc}\text { Nominal thermal output } & 20,0 \mathrm{MWt} \\ \text { Nominal water parameters } & 60 / 130^{\circ} \mathrm{C} \\ \text { Nominal steam parameters } & \\ \text { • pressure } & .35 \mathrm{MPa} \\ \text { • temperature } & 140^{\circ} \mathrm{C} \\ \text { Design pressure } & \mathrm{PN} 25\end{array}$

The Heat Transfer Station includes circulating pumps, piping, a supporting steel structure and electrical installation package.

Installation of Central Management System (CMS)

The installation of CMS has been initiated. It is assumed, that the CMS will be expanded to the distribution system and to all heat exchanger stations.

Reconstruction of a $6.2 \mathrm{kV}$ electrical distribution system.

The installation of this system was initiated.

Replacement of steam line inside the heating plant.

Limestone and coal preparation equipment

Ash dump site construction. 


\subsubsection{Investment for Heating Plant Reconstruction}

The required investment for reconstruction of the heating plant in this alternative, based on quoted prices is:

\section{Thousand SK}

Combustion reactor for steam boiler $\mathrm{K} 5$ and $\mathrm{K} 6$, material and 8,000 installation

Hot water boilers HK1 and HK2, material and installation 50,000

Turbine TG1, material and installation

30,000

Heat transfer station including circulating pumps

20,000

Central management system, material and installation

16,000

$6.2 \mathrm{kV}$ electrical distribution system

9,500

Steam piping, material and installation

6,000

Coal and limestone preparation equipment

25,000

Ash deposition site

16,000

Total Investment Required

180,500

\subsubsection{Analysis of Operation}

Thermodynamic calculations were performed for several alternative loads. The internal and distribution losses in the primary and secondary circuits were included.

\begin{tabular}{|l|r|r|r|r|}
\hline & \multicolumn{2}{|c|}{ Year 1997 } & \multicolumn{2}{c|}{ Year 2022 } \\
\hline Load Variant 1 & $42.5 \mathrm{MWt}$ & $363,710 \mathrm{GJ} / \mathrm{yr}$ & $42.5 \mathrm{MWt}$ & $363,710 \mathrm{GJ} / \mathrm{yr}$ \\
\hline Load Variant 2 & $64.02 \mathrm{MWt}$ & $549,947 \mathrm{GJ} / \mathrm{yr}$ & $65.02 \mathrm{MWt}$ & $561,853 \mathrm{GJ} / \mathrm{yr}$ \\
\hline Load Variant 3 & $64.02 \mathrm{MWt}$ & $549,947 \mathrm{GJ} / \mathrm{yr}$ & $70.11 \mathrm{MWt}$ & $600,295 \mathrm{GJ} / \mathrm{yr}$ \\
\hline
\end{tabular}

The load duration curves for the above load variants are shown in Figures 3.6, 3.7, 3.8, and 3.9. 


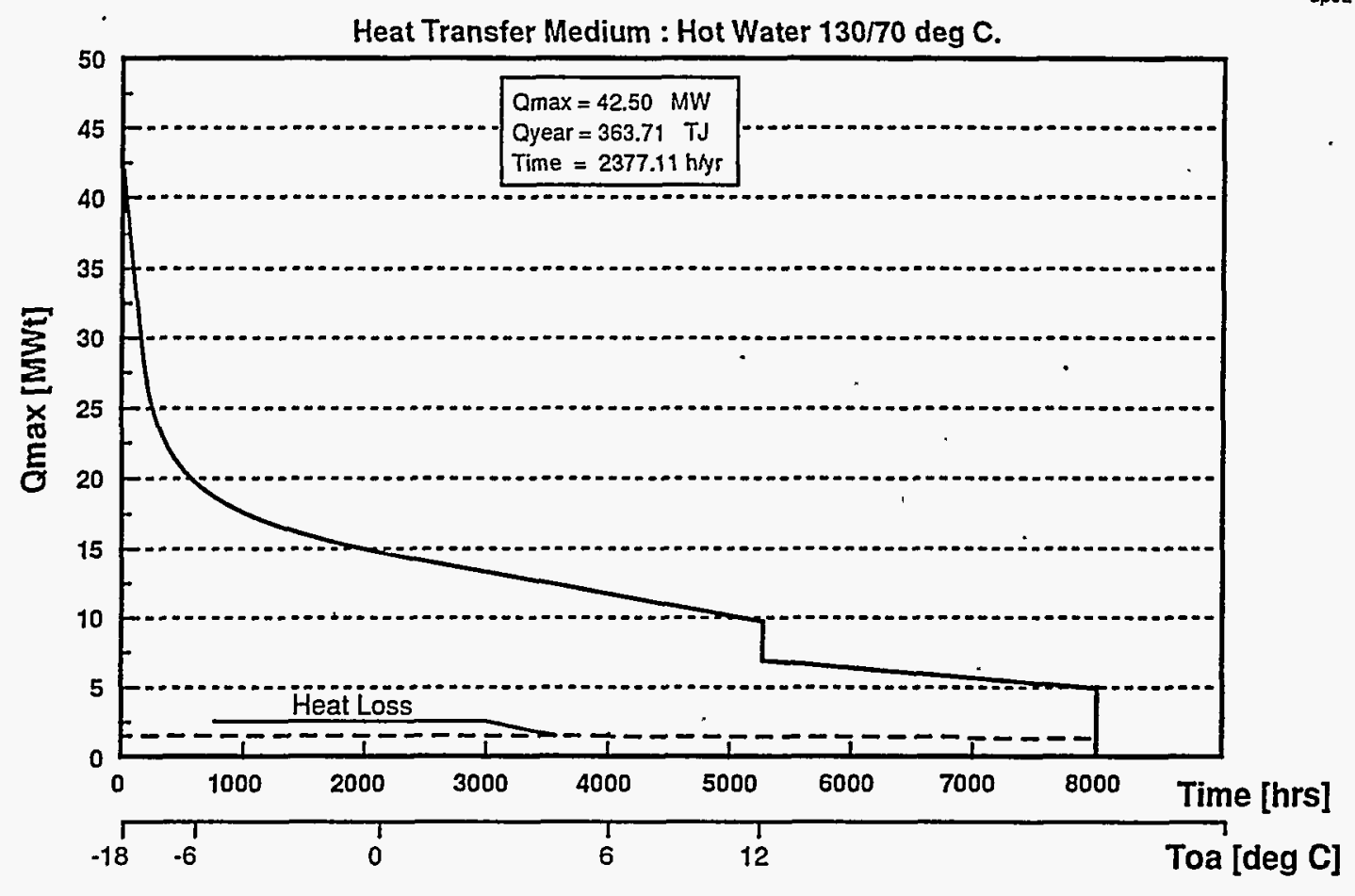

Figure 3.6 - Load Duration Curve, Heat Supply Including Distribution Losses, Variant 1

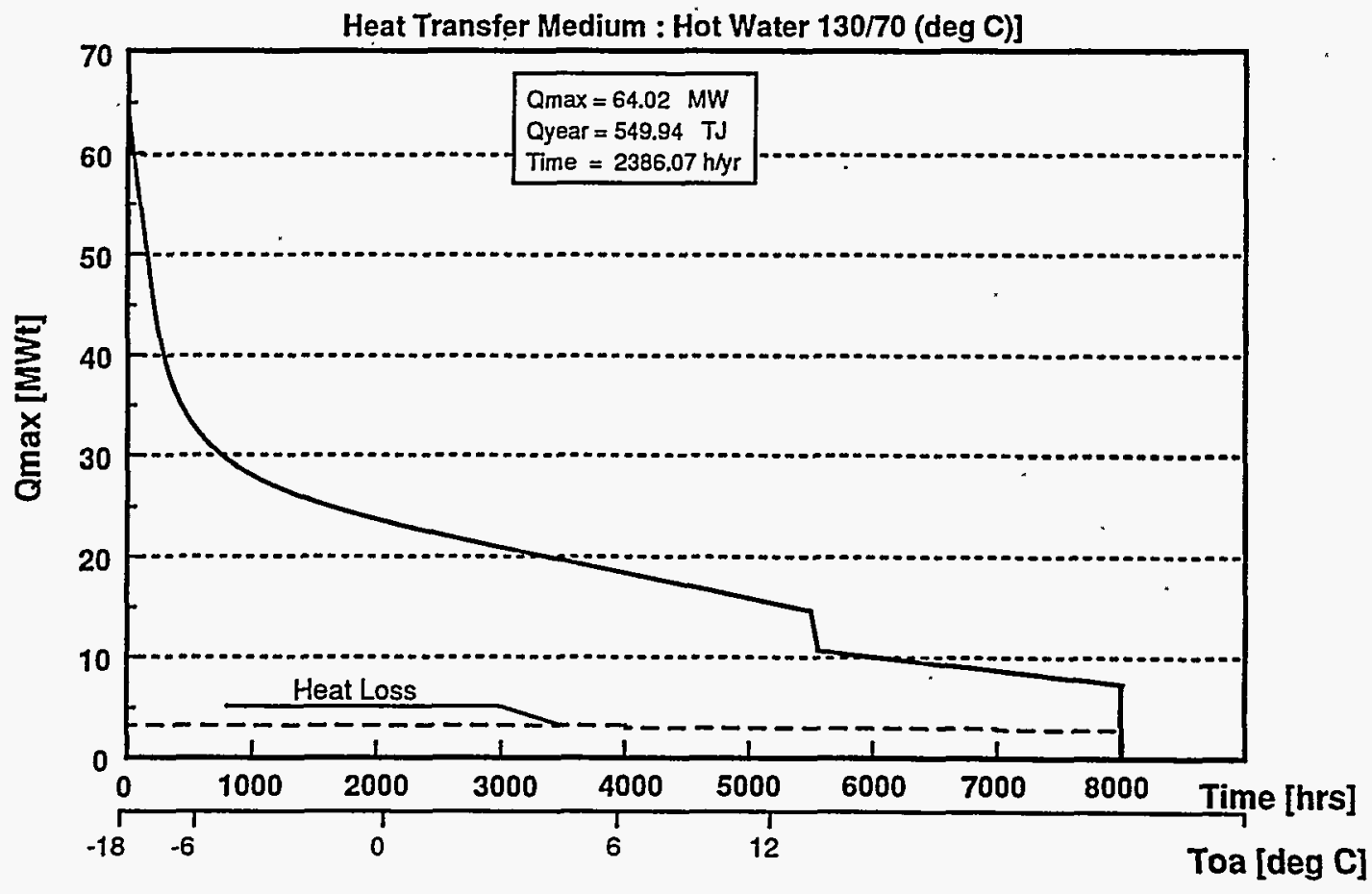

Figure 3.7 - Load Duration Curve, Heat Supply Including Distribution Losses, Variant 2 and 3 


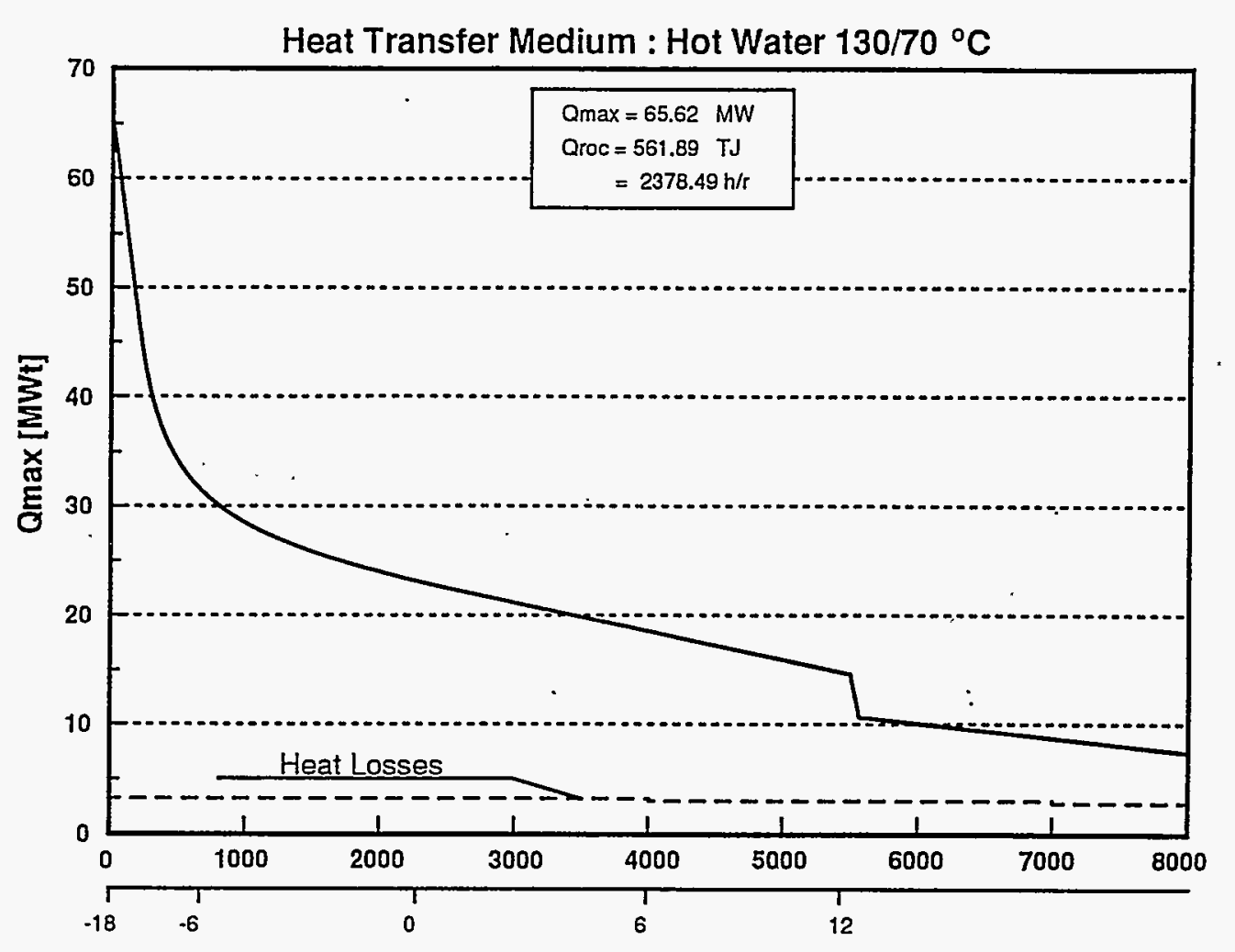

ap1394/km.fl

Figure 3.8 - Load Duration Curve, Heat Supply Including Distribution Heat Losses - Variant 2

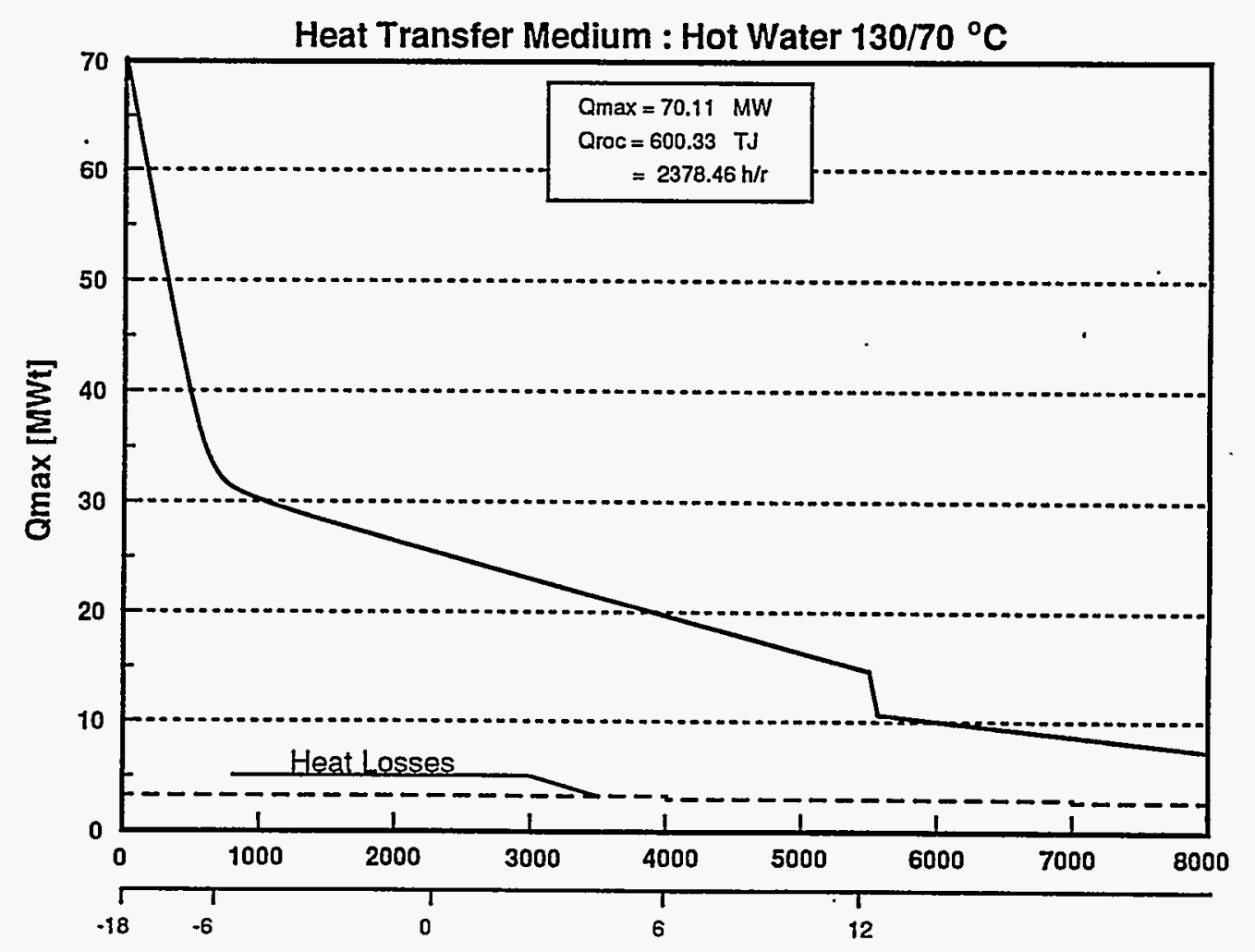

[hour] toa $\left[{ }^{\circ} \mathrm{C}\right]$

Figure 3.9 - Load Duration Curve, Heat Supply Including Distribution Heat Losses - Variant 2 
The turbine TG1, with nominal output of $4.8 \mathrm{MWe}$, is in operation only during the heating season, when average ambient air temperature drops below $12^{\circ} \mathrm{C}$. During the peak loads, the hot water boilers are operated with the baseload steam boilers. Summer load is covered only by hot water boilers. The characteristics of electricity production in load Variant 2 are shown in Figure 3.10. Table 3.1 summarizes the electricity production curve for all load variants. Table 3.2 shows turbine loads characteristics, heat production and boiler loads.

Fuel consumption for load Variant 2 expressed in thermal units is shown in Figure 3.11. Table 3.1 summarizes fuel consumption and emission production for all load variants. (Emission production limits set by Law $309 / 91 \mathrm{Zb}$ ).

The construction schedule diagram is shown in Figure 3.12.

Table 3.1 - Analyses of Operation

\section{Alternative 1}

\begin{tabular}{|c|c|c|c|c|}
\hline$\therefore \quad \therefore$ & Unit & Var 1 & Var 2 & Var.3 \\
\hline Heat Production by the plant & [GJ/year] & 363,710 & 561,856 & 600,295 \\
\hline $\begin{array}{l}\text { Fuel Consumption } \\
\qquad \begin{array}{r}\text { Coal (10.5 MJ/kg) } \\
\text { Gas (33.4 MJ/m3) }\end{array}\end{array}$ & $\begin{array}{c}\mathrm{t} / \mathrm{yr} \\
10^{6} \mathrm{~m} 3\end{array}$ & $\begin{array}{r}50,297 \\
1.947\end{array}$ & $\begin{array}{r}69,307 \\
3.947\end{array}$ & $\begin{array}{l}71,908 \\
4.254\end{array}$ \\
\hline Limestone Consumption & $t / y r$ & 5,029 & 6,931 & 7,191 \\
\hline $\begin{array}{l}\text { Internal Consumption } \\
\text { Thermal Energy } \\
\text { Electricity }\end{array}$ & $\begin{array}{c}\text { GJ/yr } \\
\text { MWh/yr }\end{array}$ & $\begin{array}{r}75,597 \\
1,280\end{array}$ & $\begin{array}{c}110,234 \\
1,790\end{array}$ & $\begin{array}{c}114,188 \\
1,890\end{array}$ \\
\hline $\begin{array}{l}\text { Production of Thermal Energy } \\
\text { Production of Electricity }\end{array}$ & $\begin{array}{c}\text { GJ/yr } \\
\text { MWh/yr }\end{array}$ & $\begin{array}{l}418,720 \\
16,030\end{array}$ & $\begin{array}{l}640,320 \\
22,400\end{array}$ & $\begin{array}{l}680,540 \\
23,620\end{array}$ \\
\hline Heat Losses in Distribution & GJ/yr & 20,623 & 31,806 & 33,979 \\
\hline $\begin{array}{l}\text { Thermal Energy Delivered } \\
\text { Electricity Delivered }\end{array}$ & $\begin{array}{c}\text { GJ/yr } \\
\text { MWh/yr }\end{array}$ & $\begin{array}{c}343,087 \\
14,750\end{array}$ & $\begin{array}{c}530,050 \\
20,610\end{array}$ & $\begin{array}{c}566,316 \\
21,730\end{array}$ \\
\hline Ash Production & $t / y r$ & 18,298 & 25,218 & 26,160 \\
\hline
\end{tabular}


Table 3.2 - Production of Thermal Energy and Electricity. Load Characteristic of the Boilers and the Turbine.

\begin{tabular}{|c|c|c|c|c|c|c|c|}
\hline \multicolumn{6}{|c|}{$2 \quad$ Ambrent Air Temperature } & \multicolumn{2}{|c|}{ Summer } \\
\hline \& $\therefore \because \because \because$ & 18 & 6 & 6 & +6 & +2 & $\operatorname{Max}$ & Min \\
\hline $\begin{array}{l}\text { Load Variant } 1 \\
\text { Boiler Loads in MWt }\end{array}$ & & & & & & & \\
\hline $\mathrm{K} 1$ & 21.25 & -- & 20.10 & 11.75 & 9.30 & -- & -- \\
\hline $\mathrm{K} 5$ & 21.25 & -- & -. & -- & -- & -- & -- \\
\hline HK1 & -- & -- & -. & -- & -- & 7.20 & 5.21 \\
\hline HK2 & -- & -- & -. & -- & -- & -- & -- \\
\hline Steam Production in $\mathrm{kg} / \mathrm{s}$ & & & & & & & \\
\hline $\mathrm{KI}$ & 8.185 & -.- & 8.730 & 4.820 & 3.903 & -- & -- \\
\hline $\begin{array}{c}\text { K2 } \\
\text { Turbine Load in MWe }\end{array}$ & 8.185 & --- & -- & -- & -- & -- & - \\
\hline$\frac{\text { TG1 }}{\text { Turhine }}$ & 4.042 & $\cdots$ & 4.288 & 2.217 & 1.704 & -- & -- \\
\hline TG1 & 7.313 & --- & 7.677 & 4.502 & 3.662 & -- & -- \\
\hline $\begin{array}{c}\text { Load Variant } 2 \\
\text { Boiler Loads in MWt }\end{array}$ & & & & & & & \\
\hline$\overline{\mathrm{K} 1}$ & 17.81 & 22.29 & 15.15 & 18.27 & 14.27 & -.. & ..- \\
\hline $\mathrm{K} 5$ & 17.81 & --- & 15.15 & --- & --. & -- & --- \\
\hline HK1 & 15.0 & 8.0 & -- & -- & -- & 11.18 & 7.13 \\
\hline $\begin{array}{c}\text { HK2 } \\
\text { Steam Production in } \mathrm{kg} / \mathrm{s}\end{array}$ & 15.0 & --- & -- & -- & --- & --- & $\cdots$ \\
\hline $\mathrm{K} 1$ & 7.072 & 8.696 & 6.332 & 8.007 & 6.138 & --. & -.. \\
\hline $\mathrm{K2}$ & 7.072 & -- & 6.332 & -.- & --- & --- & $\cdots$ \\
\hline 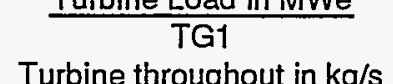 & 3.207 & 4.735 & 4.735 & 4.154 & 3.015 & -- & --. \\
\hline TG1 & 6.054 & 8.722 & 8.733 & 7.479 & 5.759 & --- & --. \\
\hline $\begin{array}{c}\text { Load Variant } 3 \\
\text { Boiler Loads in MWt }\end{array}$ & & & & & & & \\
\hline $\mathrm{K} 1$ & 20.55 & 21.86 & 16.18 & 19.51 & 15.2 & -- & --- \\
\hline K5 & 20.55 & --- & 16.18 & -- & -- & --- & -- \\
\hline HKI & 14.5 & 10.5 & $\ldots$ & -.. & -- & 11.95 & 7.72 \\
\hline $\begin{array}{c}\text { HK2 } \\
\text { Steam Production in } \mathrm{kg} / \mathrm{s}\end{array}$ & 14.5 & $\cdots$ & --- & -- & --. & --- & -- \\
\hline K1 & 8.198 & 9.535 & 6.717 & 8.59 & 6.585 & --- & --- \\
\hline $\begin{array}{c}\mathrm{K} 5 \\
\text { Turbine L oad in MWe }\end{array}$ & 8.198 & -.- & 6.717 & $\cdots$ & --- & --- & -- \\
\hline $\begin{array}{c}\text { TG1 } \\
\text { Turbine throughput in } \mathrm{kg} / \mathrm{s}\end{array}$ & 3.87 & 4.735 & 4.735 & 4.524 & 3.288 & -- & $-\cdots$ \\
\hline TG1 & 7.057 & 8.333 & 8.333 & 8.024 & 6.179 & --. & --. \\
\hline
\end{tabular}

\subsubsection{Economic Analysis}

The discounted cash flow method of analysis was used to evaluated the economic effectiveness of the project. Sensitivity analyses were performed for the delivered energy price as a function of a cost of coal, energy sales by the central district heating system, inflation and real interest. 


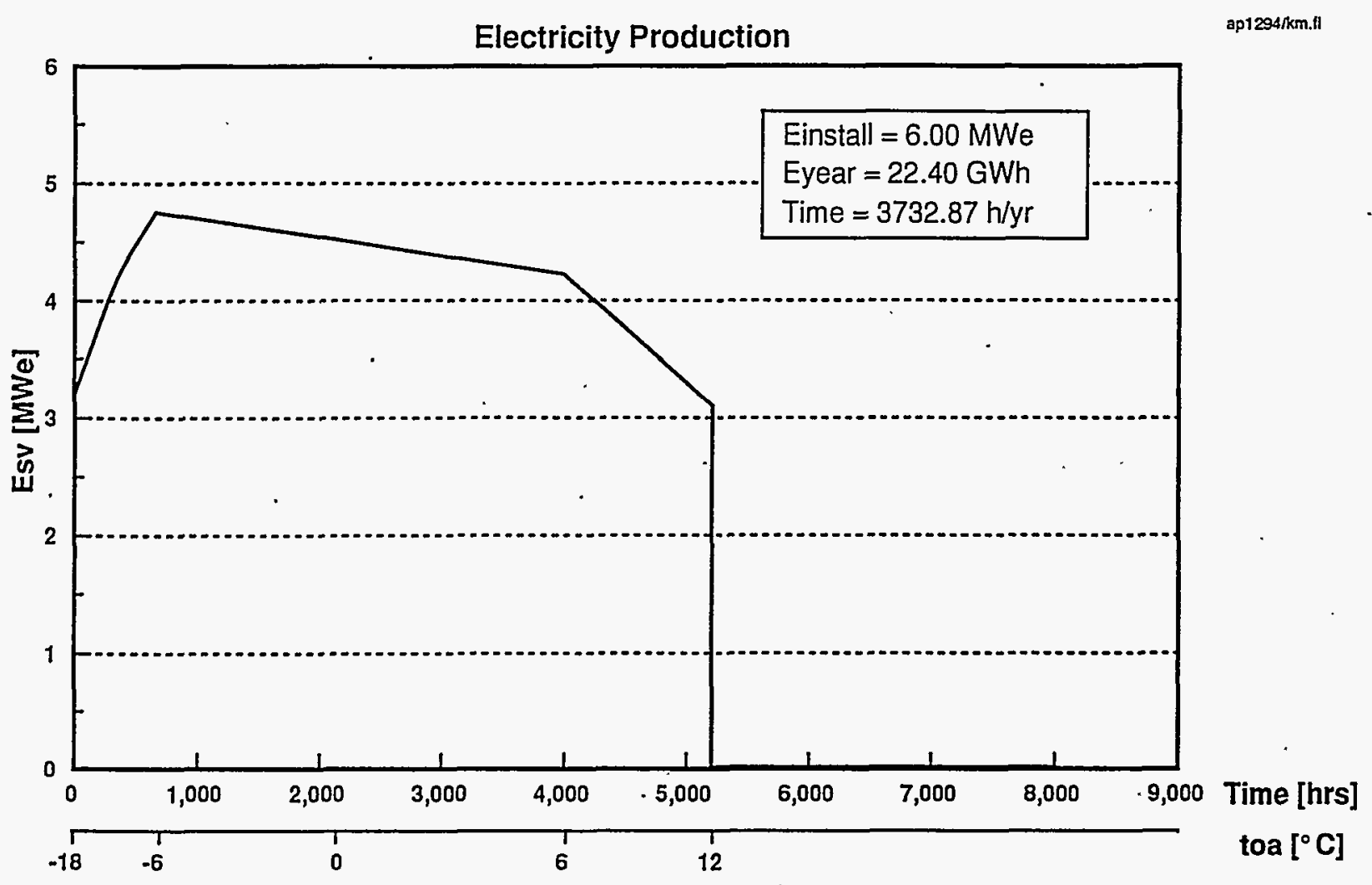

Figure 3.10 - Load Duration Curve, Output Electricity Production, Alternative 1, Load Variant 2

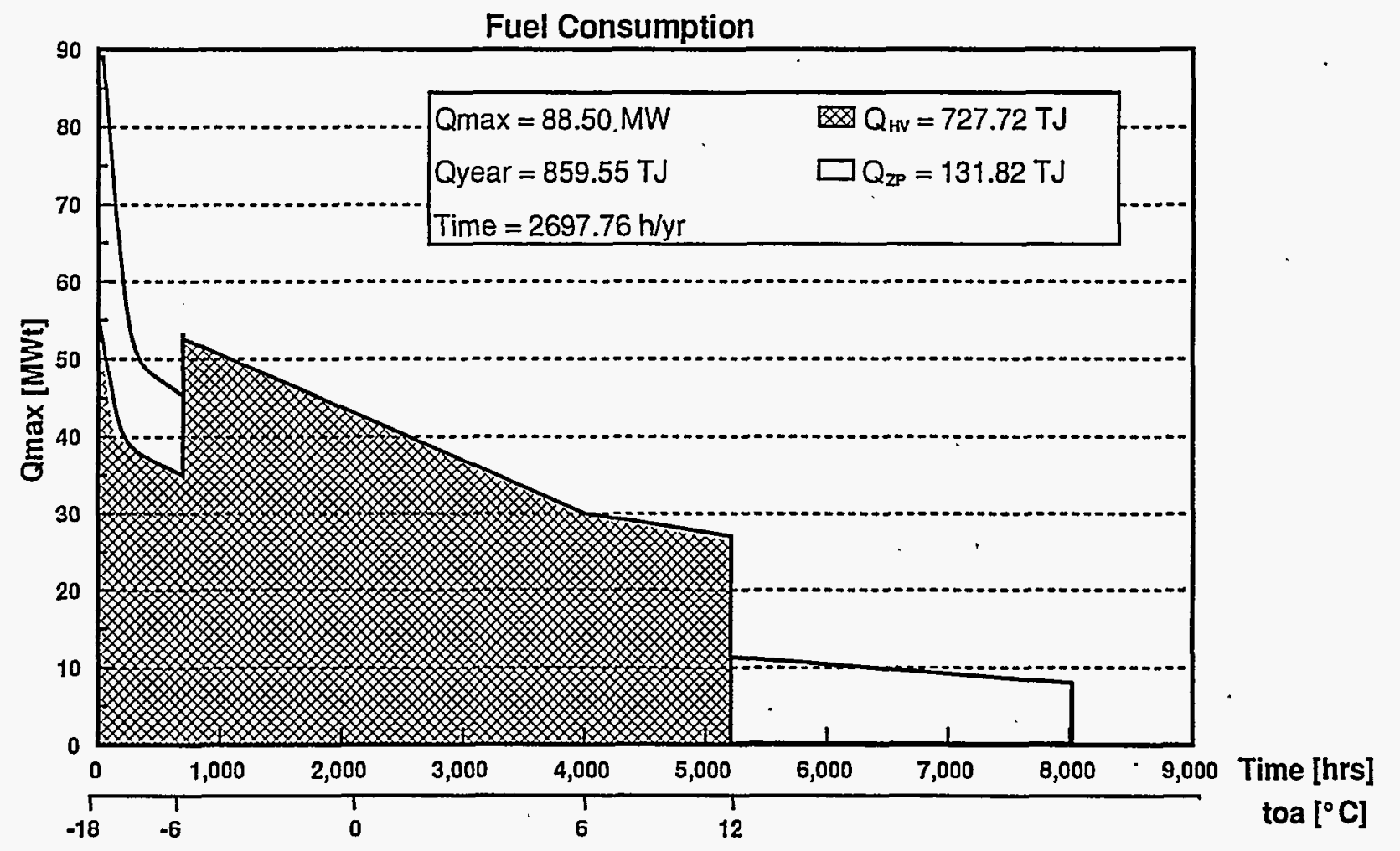

Figure 3.11 - Load Duration Curve, Output Electricity Production, Alternative 1 Load Variant 2 


\section{Heating Plant}

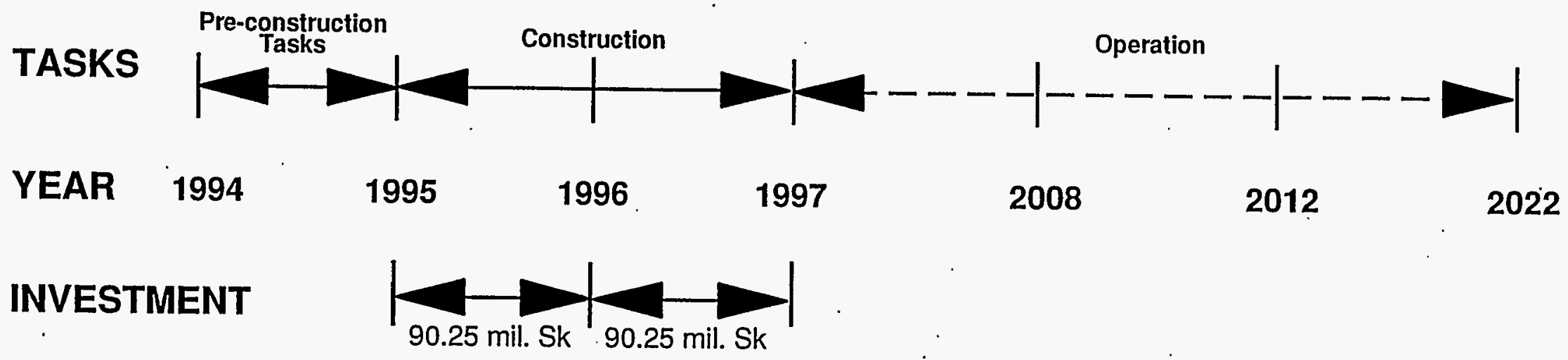

\section{Distribution}

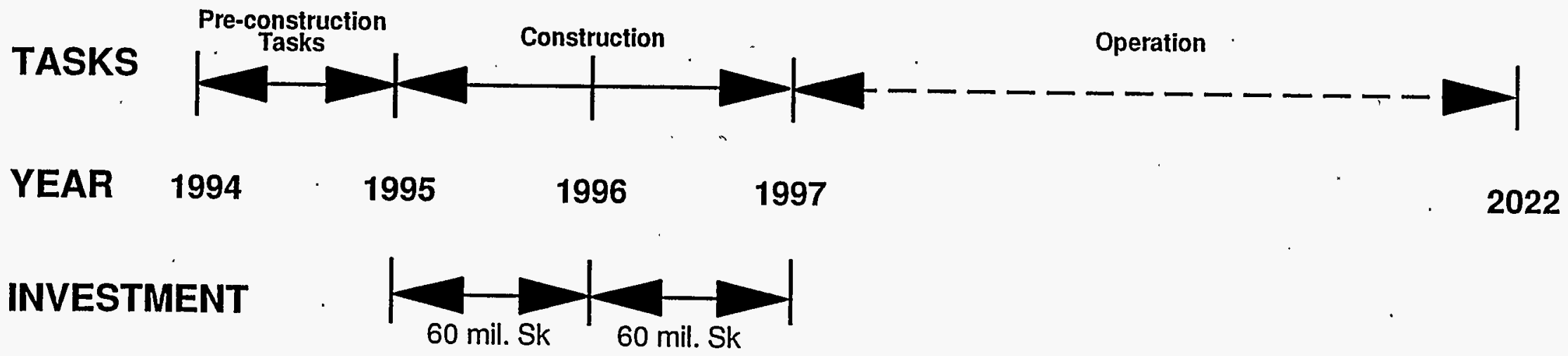

Figure 3.12 - Construction Schedule - Alternative 1 


\subsubsection{Method Used}

The discounted cash flow method analyzes the investment economics over the life of the investment. It takes into account the time the investment was executed and the time when the income is realized. The evaluation is based on the time value of money.

The evaluation can be performed to assess the complete project or to assess the attractiveness of the investment. The assessment of the project does not consider the tax consequences and the origin of the investment. Such analysis evaluate the project (system) macroeconomics. The results of such analysis are not influenced by tax system inefficiencies thus providing comparable results for all compared alternatives.

The assessment of the investment from the investors point of view takes into account tax liability and the origin of the capital. The investment analysis will provide information on the size of the required investment, investment timing and its rate of return.

\subsubsection{Analysis Metrics}

Following is a description of several metrics used in this analysis.

Discounted total profit is the sum of annual profits from the operation of the investment subject over its entire life, discounted to the year in which the investment is evaluated. It is a function of annual profits, discount rate and number of years in which the profit was realized.

Average Annual profit is annual profit, which in its constant value over the life of the investment results in identical discounted total profit. It is also called annualized profit.

Discounted cash flow, also called Net Present Value, is the sum of discounted cash flow over the life of the investment. In this project, the first year of operation of the new system was used as the basis of the calculation.

Internal Rate of Return is the discount rate which results in zero Net Present Value of the investment.

Simple Payback Period is the number of years required for the income resulting from an investment to offset the cost of the investment. Thus the lower the payback period, the more attractive the investment. 


\subsubsection{Project Economic Analysis}

Key Financial Assumptions

Construction duration

Time of start up/base year

Term of Projected Sales (Life)

Cost of Natural Gas in 1997

Cost of Coal in 1997 (four alternatives)

Fuel Cost Escalation

$\begin{array}{ll}\text { Natural Gas } & \text { from year } 1997 \text { to } 2005 \\ \text { after year } 2005\end{array}$

Coal

Rate of Return Investment

Nominal Interest Rate

Real Interest Rate

Investment Repayment Term

Investment Financed

Net Effective Tax Rate

Labor Rate

Labor Rate Escalation

Overhead

Overhead Escalation

Repairs and Maintenance

R\&M Escalation

to year 2005

Material Supplies

Materials Escalation

Other Expenses, Escalation

Depreciation of Existing Equipment

(steam distr., electrostatic filters)

In Year 1997

In Year 2000

In Year 2003

Price of electricity sold

Escalation

TOTAL PROJECT COST after 2005

2 years

1997

25 years

$3,350 \mathrm{SK} / \mathrm{m} 3$

$467.5 \mathrm{SK} / \mathrm{ton}$

$680.0 \mathrm{SK} / \mathrm{ton}$

$850.0 \mathrm{SK} / \mathrm{ton}$

$1,275 \mathrm{SK} / \mathrm{ton}$

$2.85 \%$

$1.4 \%$

$2.7 \%$

$14 \%$

$5 \%$ to $30 \%$

$2 \%, 5 \%, 9.5 \%$ and $12 \%$

10 years

$90 \%$

$45 \%$

8,750 mil. SK/yr

to year 2005

$12.4 \%$ annually

$6.0 \%$ annually

3,000 mil. SK/yr

$6.0 \%$ annually

$3.0 \%$ annually

5,000 mil. SK/yr

$7.5 \%$ annually

$3.5 \%$ annually

3,500 mil. SK/yr

$7.5 \%$ annually

$3.5 \%$ annually

$1.0 \%$ annually

1,566 mil. SK/yr

$.690 \mathrm{mil} . \mathrm{SK} / \mathrm{yr}$

.690 mil. SK/yr

1,389 SK/MWh

$6 \%$ annually

300.5 mil. SK

Fuel cost in the first year of operation is assumed to be covered from in-house funds. The cost of obtaining the loan is not accounted for and will have to be added to the total cost at the time of detailed financial analyses. 
The details of the calculations of the the economics for load Variant 2 is presented in computer.printout form in Appendix A. Figure 3.13 and Table 3.3 present the results of this analysis as function of inflation, delivered energy and the fuel cost.

The presented results shows that the delivered energy cost

- is a direct function of the cost of fuel, inflation rate and real interest

- is an inversed function of the energy sales - delivered energy

- is substantially influenced by investment approach, pricing policy and by quantity of delivered energy (sales). For example, $50 \%$ financing (compared to $90 \%$ ) will reduce the cost of delivered energy by 15 SK/GJ; a 200 SK/MWh increase in the price of electricity sold will reduce the cost of delivered heat by approximately 10 SKIGJ.

\subsection{ALTERNATIVE 2 : CENTRAL DISTRICT HEATING SYSTEM WITH COGENERATION, COAL FIRED}

This alternative assumes reconstruction of existing boilers $K 5$ and $K 6$, coal supply equipment, ash removal equipment and hot water manifolds, completion of a new chemical plant for water treatment, installation of a new $6.2 \mathrm{~kW}$ electrical distribution center, new mechanical room, new hot water heat exchanger station, and a new ash dump site. A general schematic of the system is shown in Figure 3.14.

\subsubsection{Equipment specification:}

Boiler K1 - steam boiler made by "Prvni Brnenska Strojirna", retrofitted in 1982 (upstream combustion reactor addition)

$\begin{array}{ll}\text { Max. boiler output } & 30 \mathrm{MWt} \\ \text { Max. mass flow } & 35 \mathrm{t} / \mathrm{hr} \\ \text { Nominal steam pressure } & 3.6 \mathrm{MPa} \\ \text { Nominal steam temperature } & 425^{\circ} \mathrm{C} \\ \text { Nominal water temperature } & 110^{\circ} \mathrm{C} \\ \text { Thermal efficiency } & 77 \%\end{array}$

Fuel brown coal

Note : Reconstruction of this boiler - installation of the up-stream reactor -was already performed 

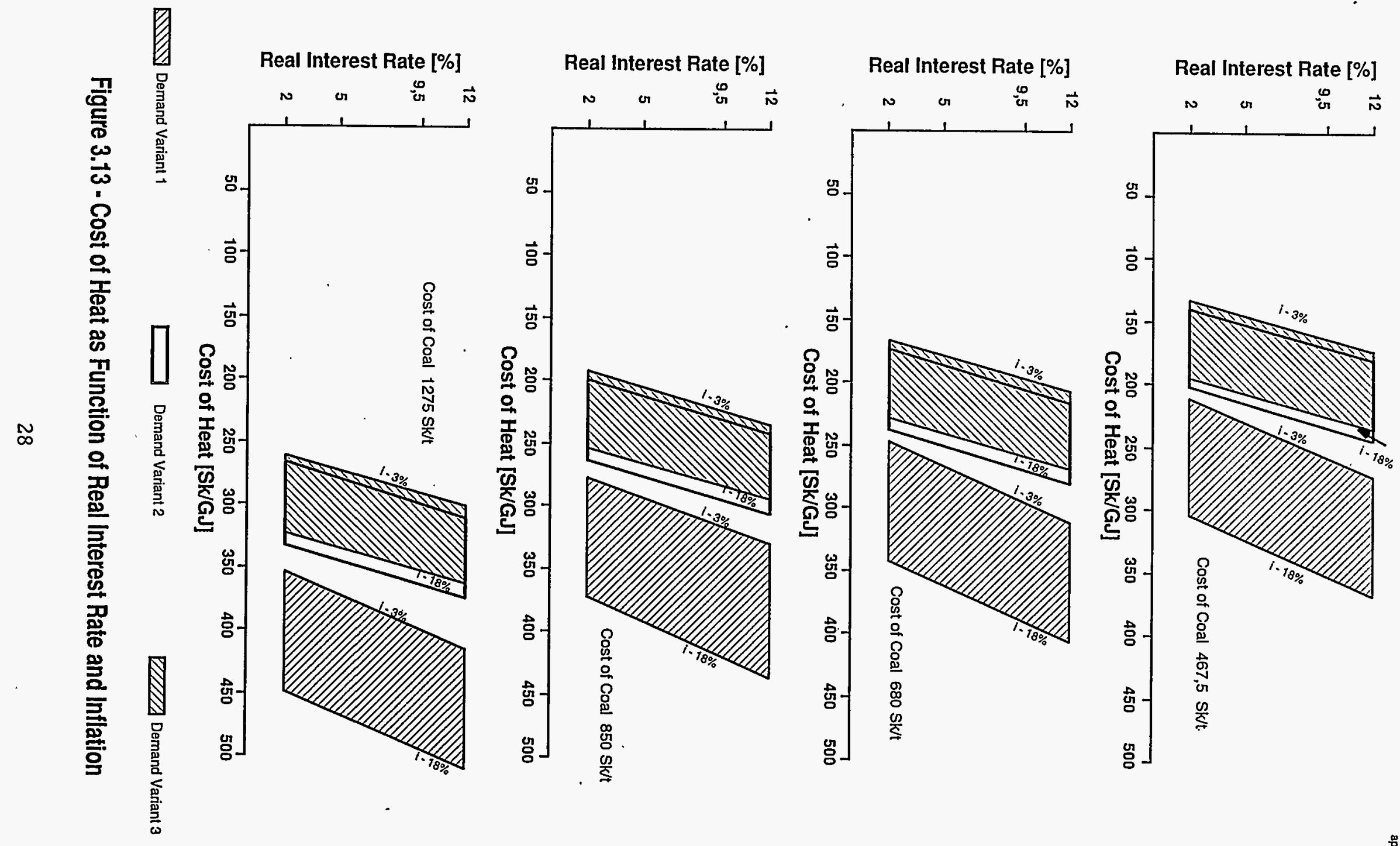
Table 3.3 - Cost of Heat, Alternative 1

\begin{tabular}{|c|c|c|c|c|c|}
\hline $\begin{array}{l}\text { Coalcost } \\
\text { [Skit] }\end{array}$ & $\begin{array}{l}\text { Discount } \\
\text { rate } \\
\text { fo] }\end{array}$ & Inflation & 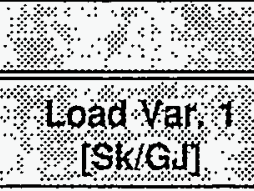 & 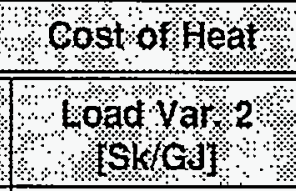 & 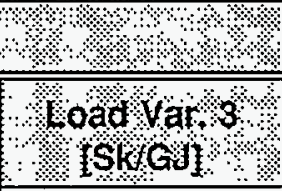 \\
\hline \multirow{3}{*}{467} & 5 & $\begin{array}{c}3 \\
18\end{array}$ & $\begin{array}{l}221,00 \\
317,30\end{array}$ & $\begin{array}{l}159,95 \\
225,30\end{array}$ & $\begin{array}{l}155,33 \\
217,50\end{array}$ \\
\hline & 9,5 & $\begin{array}{c}3 \\
18\end{array}$ & $\begin{array}{l}261,10 \\
341,40\end{array}$ & $\begin{array}{l}187,15 \\
242,05\end{array}$ & $\begin{array}{l}181,20 \\
233,60\end{array}$ \\
\hline & 12 & $\begin{array}{c}3 \\
18\end{array}$ & $\begin{array}{l}274,50 \\
355,00\end{array}$ & $\begin{array}{l}196,25 \\
251,40\end{array}$ & $\begin{array}{l}189,80 \\
242,50\end{array}$ \\
\hline \multirow{4}{*}{680} & 2 & $\begin{array}{c}3 \\
18\end{array}$ & $\begin{array}{l}253,10 \\
333,30\end{array}$ & $\begin{array}{l}188,75 \\
243,20\end{array}$ & $\begin{array}{l}183,90 \\
235,60\end{array}$ \\
\hline & 5 & $\begin{array}{c}3 \\
18\end{array}$ & $\begin{array}{l}269,15 \\
349,40\end{array}$ & $\begin{array}{l}199,65 \\
254,10\end{array}$ & $\begin{array}{l}194,25 \\
246,05\end{array}$ \\
\hline & 9,5 & $\begin{array}{c}3 \\
18\end{array}$ & $\begin{array}{l}293,20 \\
373,50\end{array}$ & $\begin{array}{l}216,00 \\
270,80\end{array}$ & $\begin{array}{l}209,75 \\
262,10\end{array}$ \\
\hline & 12 & $\begin{array}{c}3 \\
18\end{array}$ & $\begin{array}{l}306,60 \\
387,00\end{array}$ & $\begin{array}{l}225,05 \\
280,20\end{array}$ & $\begin{array}{l}218,40 \\
271,05\end{array}$ \\
\hline \multirow{4}{*}{850} & 2 & $\begin{array}{c}3 \\
18\end{array}$ & $\begin{array}{l}278,70 \\
359,00\end{array}$ & $\begin{array}{l}211,75 \\
266,20\end{array}$ & $\begin{array}{l}206,73 \\
258,45\end{array}$ \\
\hline & 5 & $\begin{array}{c}3 \\
18\end{array}$ & $\begin{array}{l}294,80 \\
375,00\end{array}$ & $\begin{array}{l}222,65 \\
277,10\end{array}$ & $\begin{array}{l}217,05 \\
268,80\end{array}$ \\
\hline & 9,5 & $\begin{array}{c}3 \\
18 \\
\end{array}$ & $\begin{array}{l}318,80 \\
399,10 \\
\end{array}$ & $\begin{array}{l}239,00 \\
293,75 \\
\end{array}$ & $\begin{array}{l}232,60 \\
284,90\end{array}$ \\
\hline & 12 & $\begin{array}{c}3 \\
18\end{array}$ & $\begin{array}{l}332,20 \\
412,60\end{array}$ & $\begin{array}{l}248,05 \\
303,15\end{array}$ & $\begin{array}{l}241,20 \\
293,80\end{array}$ \\
\hline \multirow{4}{*}{1275} & 2 & $\begin{array}{c}3 \\
18\end{array}$ & $\begin{array}{l}342,75 \\
423,00\end{array}$ & $\begin{array}{l}269,25 \\
323,70\end{array}$ & $\begin{array}{l}263,75 \\
315,45\end{array}$ \\
\hline & 5 & $\begin{array}{c}3 \\
18 \\
\end{array}$ & $\begin{array}{l}358,80 \\
439,00 \\
\end{array}$ & $\begin{array}{c}280,15 \\
34,60\end{array}$ & $\begin{array}{l}274,10 \\
325,80\end{array}$ \\
\hline & 9,5 & $\begin{array}{c}3 \\
18\end{array}$ & $\begin{array}{l}382,90 \\
463,10\end{array}$ & $\begin{array}{l}296,50 \\
351,10\end{array}$ & $\begin{array}{l}289,60 \\
431,85\end{array}$ \\
\hline & 12 & $\begin{array}{c}3 \\
18\end{array}$ & $\begin{array}{l}396,25 \\
476,50\end{array}$ & $\begin{array}{l}305,55 \\
360,50\end{array}$ & $\begin{array}{l}298,20 \\
350,80\end{array}$ \\
\hline
\end{tabular}




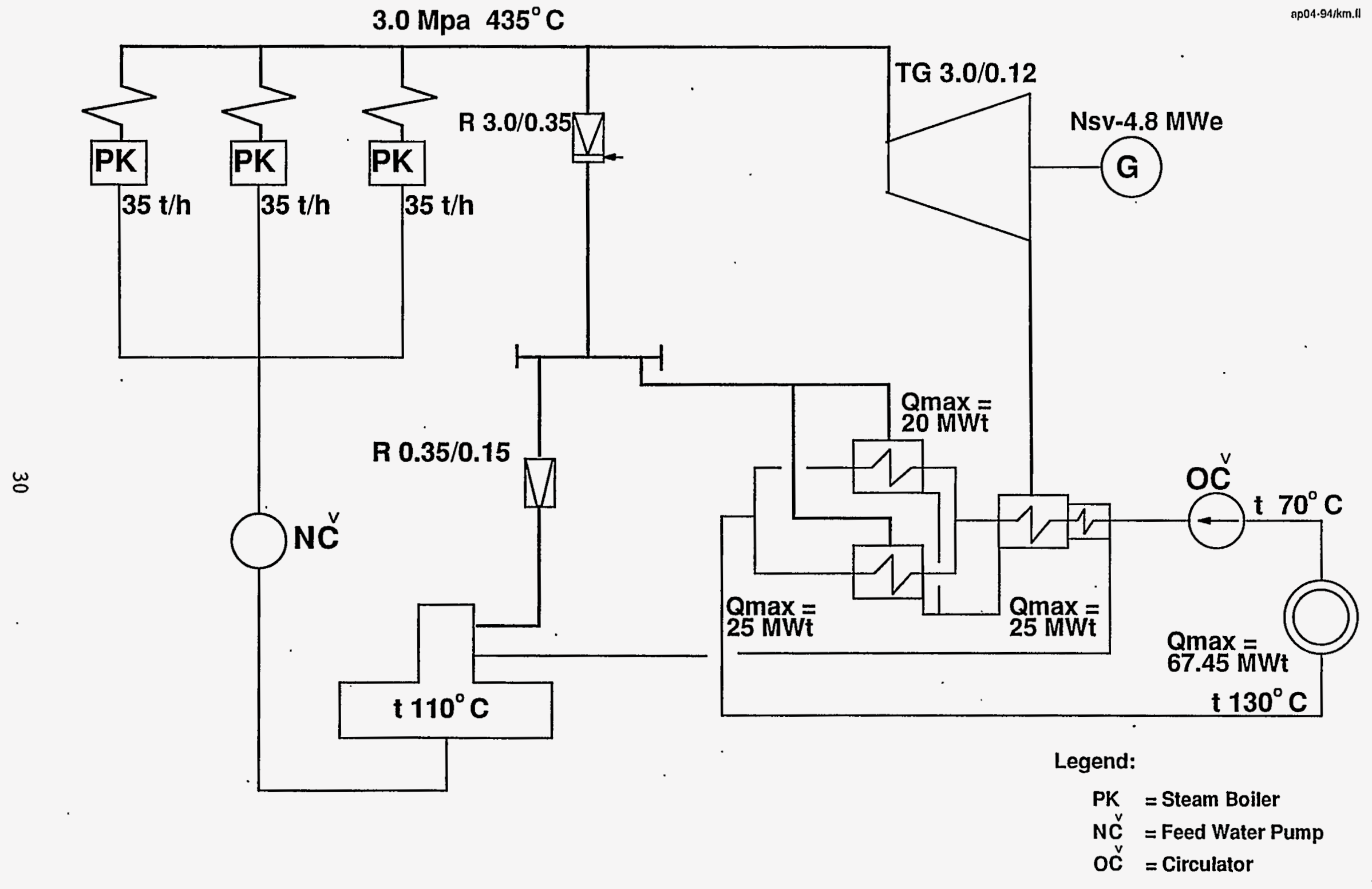

Figure 3.14 - Equipment Diagram, Alternative 2 
Boiler K5 - steam boiler made by "Pruni Brnenska Strojirna". Recommended reconstruction and installation of up-stream combustion reactor in 1995.

Max. boiler output

Max. mass flow

Nominal steam pressure

Nominal steam temperature

Nominal water temperature

Thermal efficiency
$30 \mathrm{MWt}$

$35 \mathrm{t} / \mathrm{hr}$

3.6 $\mathrm{MPa}$

$425^{\circ} \mathrm{C}$

$110^{\circ} \mathrm{C}$

$77 \%$

Fuel

brown coal

Note: This boiler will be retrofitted and equipped with up-stream combustion reactor.

Boiler K6 steam boiler made by "Prvni Brnenska Strojirna". Recommended reconstruction and installation of up-stream combustion reactor in 1995.

Max. boiler output

Max. mass flow

Nominal steam pressure

Nominal steam temperature

Nominal water temperature

Thermal efficiency

Fuel
$30 \mathrm{MWt}$

$35 \mathrm{t} / \mathrm{hr}$

$$
\begin{aligned}
& 3.6 \mathrm{MPa} \\
& 425^{\circ} \mathrm{C} \\
& 110^{\circ} \mathrm{C} \\
& 77 \%
\end{aligned}
$$

brown coal

Note: this boiler will be retrofitted and equipped with up-stream combustion reactor.

TG1 - 4.8 MWe back-pressure steam turbine made by "Prvni Brnenska

Strojirna"

$\begin{array}{lc}\text { Nominal electrical output } & 4.8 \mathrm{MWe} \\ \text { Steam throughput at nominal parameters } & 40 \mathrm{t} / \mathrm{hr} \\ \text { Nominal steam parameters: } & \\ \text { • pressure } & 3.2 \mathrm{MPa} \\ \text { • temperature } & 420^{\circ} \mathrm{C} \\ \text { Back-pressure turndown } & .035-.35 \mathrm{MPa} \\ & \\ \text { Generator: } & \\ \text { - Nominal RPM } & 3,0001 / \mathrm{min} \\ \text { - Nominal Power Output } & 6,000 \mathrm{kVA} \\ \text { - Voltage } & 6.3 \mathrm{kV} \\ \text { - Frequency } & 50 \mathrm{~Hz}\end{array}$

The turbine package includes control and safety equipment, lubrication package, leakage steam condensation package and piping. 
Heat Transfer Station including circulation pumps

2 pieces of tube and shell steam-to-water heat exchanger

Nominal thermal output $25,0 \mathrm{MWt}$

Nominal water parameters

$60 / 94^{\circ} \mathrm{C}$

Nominal steam parameters

- pressure

$.12 \mathrm{MPa}$

- temperature $105^{\circ} \mathrm{C}$

Design pressure

PN 25

1 piece of tube and shell steam-to-water heat exchanger

Nominal thermal output

Nominal water parameters

Nominal steam parameters

$20,0 \mathrm{MWt}$

- pressure

- temperature

$60 / 130^{\circ} \mathrm{C}$

Design pressure

$.35 \mathrm{MPa}$

$140^{\circ} \mathrm{C}$

PN 25

The Heat Transfer Station includes circulating pumps, piping, supporting steel structure and electrical installation package.

Installation of Central Management System (CMS)

The installation of the CMS has been initiated. It is assumed, that the.CMS will be expanded to the distribution system and to all heat exchanger stations.

Reconstruction of a $6.2 \mathrm{kV}$ electrical distribution system.

The installation of this system was initiated.

Replacement of steam line inside the heating plant.

Limestone and coal preparation equipment

Ash dump site construction. 


\subsubsection{Investment for Heating Plant Reconstruction}

The required investment for reconstruction of the heating plant in this alternative, based on quoted prices, is:

Thousand SK

Combustion reactor for steam boiler $\mathrm{K} 5$ and $\mathrm{K} 6$, material and 16,000 installation

Turbine TG1, material and installation 30,000

Heat transfer station including circulating pumps 23,000

Central management system, material and installation 16,000

$6.2 \mathrm{kV}$ electrical distribution system 9,500

Steam piping, material and installation 6,000

Coal and limestone preparation equipment 25,000

Ash deposition site 16,000

Total Investment Required

141,500

\subsubsection{Analysis of Operation}

Thermodynamic calculations were performed for several alternative loads. The internal and distribution losses in the primary and secondary circuits were included. The same method was used as for Alternative 1. The load duration curves are shown in Figures 3.6, 3.7, 3.8 and 3.9. The turbine $T G 1(4.8 \mathrm{MWe})$ is operated all year round.

The characteristics of electricity production in load Variant 2 are shown in Figure 3.15. Table 3.4 summarizes the electricity production curve for fuel consumption and emission production for all load variants. (Emission production limits are set by Law 309/91 Zb.) Table 3.5 shows the turbine loads characteristics. The heat production, turbine loads characteristics and boiler loads are shown in Table 3.5 .

Fuel consumption for load Variant 2 expressed in thermal units is shown in Figure 3.16.

The construction schedule diagram is shown in Figure 3.17 


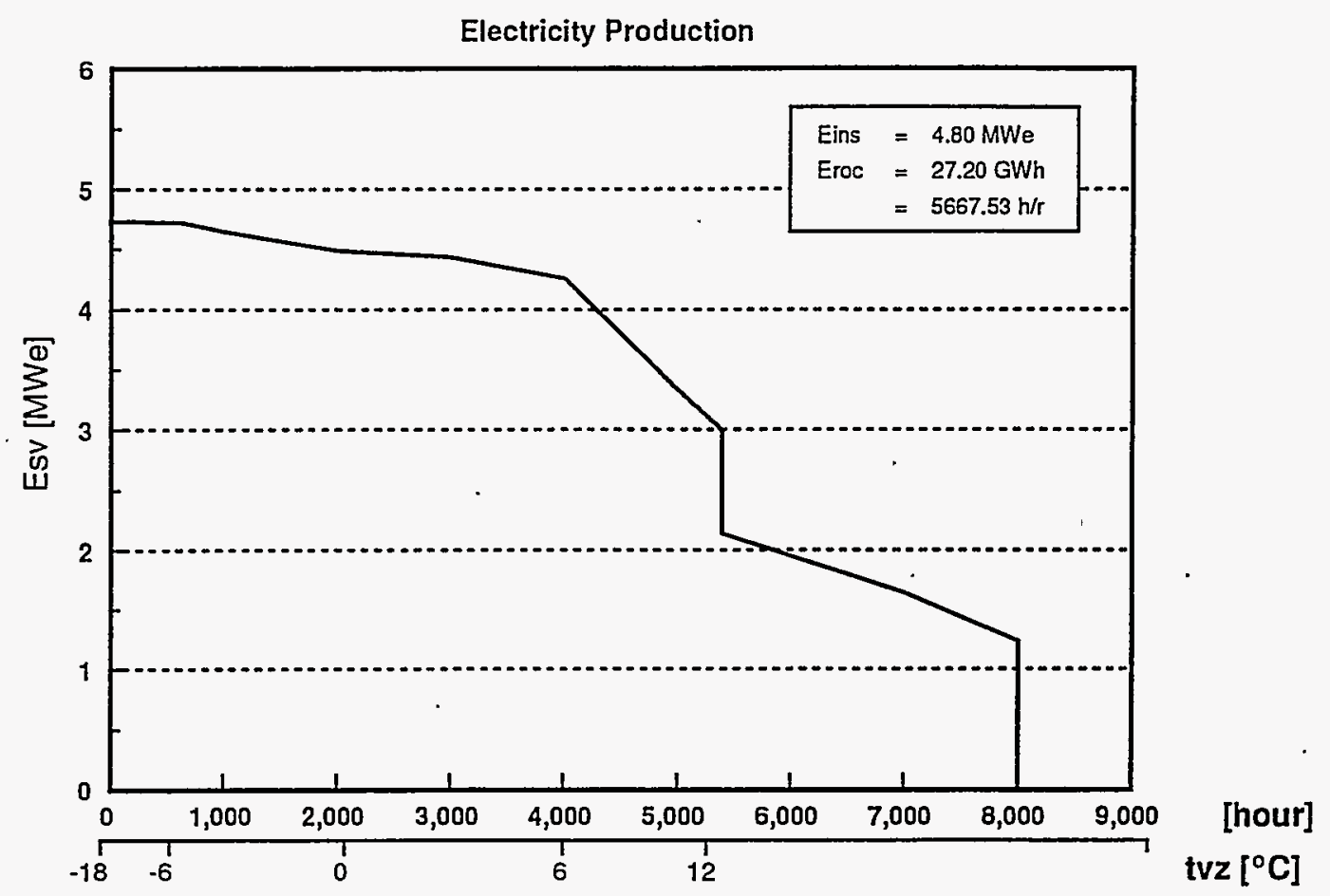

Figure 3.15 - Load Duration Curve, Output Electricity Production, Alternative 2, Load Variant 2

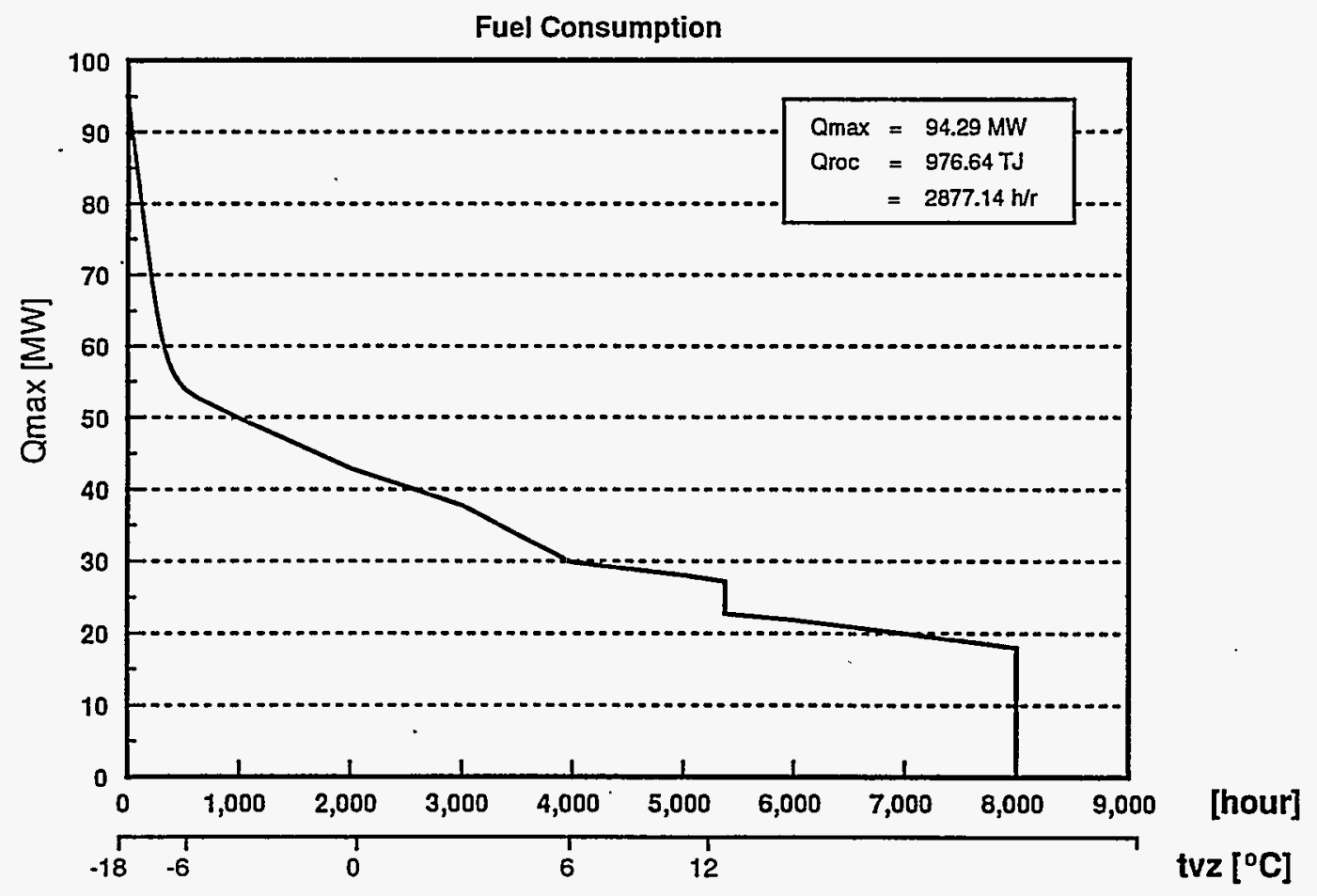

Figure 3.16 - Load Duration Curve, Fuel Consumption, Alternative 2 Load Variant 2 
Table 3.4 - Analyses of Operation

Alternative 2

\begin{tabular}{|c|c|c|c|c|}
\hline 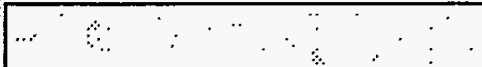 & Unit: & Var 1 & Yar. 2 & $\operatorname{Var} 3$ \\
\hline Heat Production by the plant & [GJ/year] & 363,710 & 561,865 & 600,295 \\
\hline $\begin{array}{l}\text { Fuel Consumption } \\
\qquad \text { Coal (10.5 MJ/kg) }\end{array}$ & $t / y r$ & 64,059 & 93,013 & 106,327 \\
\hline Limestone Consumption & $t / y r$ & 5,030 & 9,301 & 10,633 \\
\hline $\begin{array}{l}\text { Internal Consumption } \\
\text { Thermal Energy } \\
\text { Electricity }\end{array}$ & $\begin{array}{l}\text { GJ/yr } \\
M W h / y r\end{array}$ & $\begin{array}{l}64,070 \\
1,490\end{array}$ & $\begin{array}{c}94,209 \\
2,180\end{array}$ & $\begin{array}{c}100,406 \\
2,300\end{array}$ \\
\hline $\begin{array}{l}\text { Production of Thermal Energy } \\
\text { Production of Electricity }\end{array}$ & $\begin{array}{l}\text { GJ/yr } \\
\text { MWh/yr }\end{array}$ & $\begin{array}{c}427,780 \\
18,610\end{array}$ & $\begin{array}{l}656,100 \\
27,200\end{array}$ & $\begin{array}{l}700,740 \\
28,740\end{array}$ \\
\hline Heat Losses in Distribution & GJ/yr & 20,623 & 31,806 & 33,979 \\
\hline $\begin{array}{l}\text { Thermal Energy Delivered } \\
\text { Electricity Delivered }\end{array}$ & $\begin{array}{l}\text { GJ/yr } \\
\mathrm{MWh} / \mathrm{yr}\end{array}$ & $\begin{array}{c}343,087 \\
17,210\end{array}$ & $\begin{array}{c}530,050 \\
25,020\end{array}$ & $\begin{array}{l}566,316 \\
26,440\end{array}$ \\
\hline Ash Production & $t / y r$ & 32,599 & 47,334 & 38,681 \\
\hline
\end{tabular}


Table 3.5 - Production of Thermal Energy and Electricity. Load Characteristic of the Boilers and the Turbine.

\begin{tabular}{|c|c|c|c|c|c|c|}
\hline Ambienta & Tempe & atüre & & & $: \mathbf{S u}$ & ner \\
\hline ध $\because$ औ & 18 & 66 & +6 & +12 & Wax & Min: \\
\hline $\begin{array}{c}\text { Load Variant } 1 \\
\text { Boiler Loads in MWt }\end{array}$ & & & & & & \\
\hline $\mathrm{K} 1$ & 21.25 & 20.10 & 11.35 & 9.30 & 7.2 & 5.21 \\
\hline K5 & 21.25 & --. & -- & -- & --- & $\because$ \\
\hline$K 6$ & -- & --- & --- & -- & --- & --- \\
\hline Steam Production in kg/s & & & & & & \\
\hline $\mathrm{K} 1$ & 8.485 & 8.730 & 4.820 & 3.903 & 2.972 & 2.104 \\
\hline K5 & 8.485 & -- & -.. & -- & -- & --. \\
\hline K6 & -.. &.-- & $\cdots$ & -- & -.- & --- \\
\hline Turbine Load in MWe & & & & & & \\
\hline$\frac{T G 1}{T}$ & 4.042 & 4.288 & 2.217 & 1.704 & 1.190 & .737 \\
\hline TG1 & 7.313 & 7.667 & 4.502 & 3.662 & 2.788 & 1.974 \\
\hline $\begin{array}{c}\text { Load Variant } 2 \\
\text { Boiler Loads in MWt }\end{array}$ & & & & & & \\
\hline$\overline{K 1}$ & 21.33 & 17.05 & 15.45 & 13.78 & 11.10 & 7.12 \\
\hline K5 & 21.33 & 15.05 & --- & -- & $\cdots$ & -- \\
\hline $\begin{array}{c}\mathrm{K} 6 \\
\text { Steam Production in } \mathrm{kg} / \mathrm{s}\end{array}$ & 21.34 & 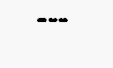 & -- & -- & -- & -- \\
\hline $\mathrm{KI}$ & 8.395 & 6.297 & 7.600 & 5.931 & 4.711 & 2.936 \\
\hline K5 & 8.395 & 6.297 & --- & - & - & -- \\
\hline $\mathrm{K} 5$ & 8.395 & --- & $\cdots$ & -- & -- & -- \\
\hline Turbine Load in MWe & & & & & & \\
\hline$\frac{\mathrm{TG1}}{\text { Turbine throughput in } \mathrm{kg} / \mathrm{s}}$ & 4.735 & 4.735 & 3.888 & 2.889 & 2.166 & 1.171 \\
\hline TGI & 8.333 & 8.333 & 7.099 & 5.565 & 4.420 & 2.755 \\
\hline $\begin{array}{c}\text { Load Variant } 3 \\
\text { Boller Loads in MWt }\end{array}$ & & & & & & \\
\hline $\mathrm{K} 1$ & 23.37 & 16.18 & 19.51 & 15.20 & 11.95 & 7.72 \\
\hline K5 & 23.37 & 16.18 & -- & --- & $\cdots$ & -- \\
\hline $\begin{array}{c}\mathrm{K} 6 \\
\text { Steam Production in } \mathrm{kg} / \mathrm{s}\end{array}$ & 23.37 & --- & --- & - & --- & - \\
\hline $\mathrm{K} 1$ & 9.151 & 6.717 & 8.590 & 6.585 & 5.096 & 3.201 \\
\hline K5 & 9.151 & 6.717 & -- & -- & --- & - \\
\hline $\begin{array}{r}K 6 \\
\text { Turbine Load }\end{array}$ & 9.151 & -.. & - & --- & $-\cdots$ & -- \\
\hline $\begin{array}{l}\text { TG1 } \\
\text { Turbine throughput in } \mathrm{kg} / \mathrm{s}\end{array}$ & 4.735 & 4.735 & 4.524 & 3.288 & 2.391 & 1.314 \\
\hline TG1 & 8.333 & 8.333 & 8.024 & 6.179 & 4.782 & 3.003 \\
\hline
\end{tabular}




\section{Heating Plant}

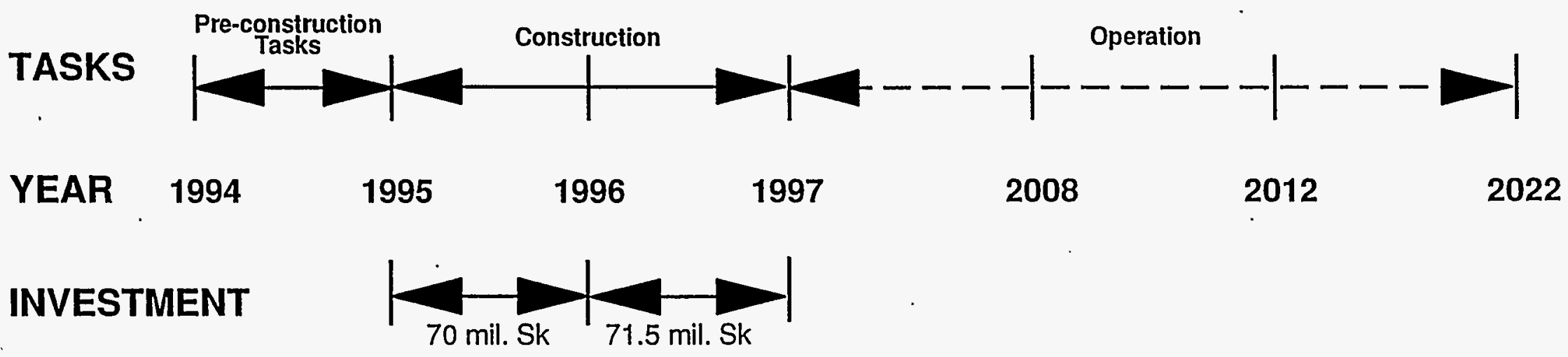

Distribution

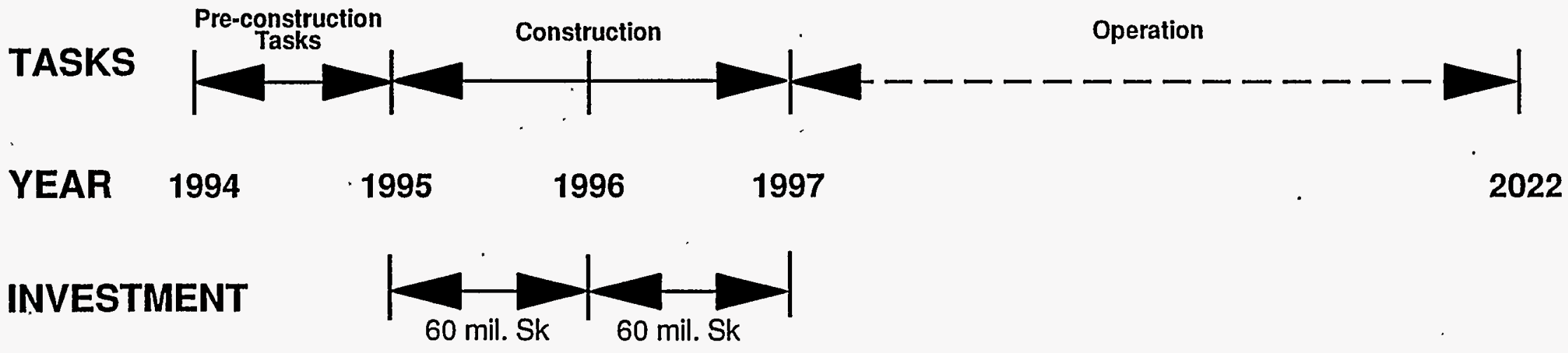

Figure 3.17 - Construction Schedule, Alternative 2 


\subsubsection{Project Economic Analysis}

\section{$\underline{\text { Key Financial Assumptions }}$}

Construction duration

Time of start up/base year

Term of Projected Sales (Life)

Cost of Natural Gas in 1997

Cost of Coal in 1997 (four alternatives)

Fuel Cost Escalation

Coal

Rate of Return Investment

Nominal Interest Rate

Real Interest Rate

Investment Repayment Term

Investment Financed

Net Effective Tax Rate

Labor Rate

Labor Rate Escalation to year 2005

after 2005

Overhead

Overhead Escalation to year 2005

after 2005

Repairs and Maintenance

R\&M Escalation to year 2005

after 2005

Material Supplies

Materials Escalation

to year 2005

after 2005

Other Expenses, Escalation

Amortization of Existing Equipment

(steam distr., electro-installation)

In Year 1997

In. Year 2000

In Year 2003

Price of Electricity Sold

Escalation

TOTAL PROJECT COST
2 years

1997

25 years

$3,350 \mathrm{SK} / \mathrm{m3}$

467.2 SK/ton

$680.0 \mathrm{SK} / \mathrm{ton}$

$850.0 \mathrm{SK} / \mathrm{ton}$

1,275 SK/ton

$2.7 \%$

$14 \%$

$5 \%$ to $30 \%$

$2 \%, 5 \%, 9.5 \%$ and $12 \%$

10 years

$90 \%$

$45 \%$

8,750 mil. SK/yr

$12.4 \%$ annually

$6 \%$ annually

3,000 mil. SK/yr

$6.0 \%$ annually

$3.0 \%$ annually

5,000 mil. SK/yr

$7.5 \%$ annually

$3.5 \%$ annually

3,500 mil. SK/yr

$7.5 \%$ annually

$3.5 \%$ annually

$1.0 \%$ annually

¡,566 mil. SK/yr

.690 mil. SK/yr

.690 mil. SK/yr

1,389 Sk/Mwh

$6 \%$ annually

261.5 mil. SK

Fuel cost in first year of operation is assumed to be covered from in-house funds. The cost of obtaining the loan is not accounted for and will have to be added to the total cost at the time of detailed financial analyses. 
Figure 3.18 and Table 3.6 present the results of this analysis as a function of inflation, delivered energy and fuel cost.

The comparison with Alternative 1 shows that cogeneration in the summer as well as the winter improves the economics. The positive impact of electricity sales is greater than the negative impact of greater emission production and its cost. The cost of delivered thermal energy is lower in this alternative (compared to Alternative 1). 


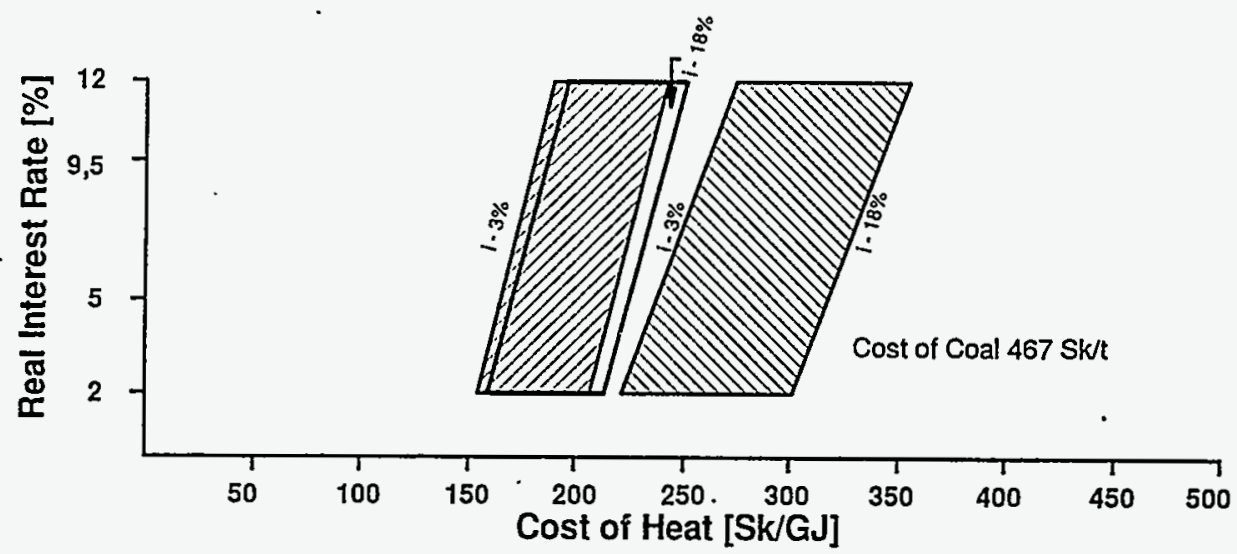

ap03-94/km.fl
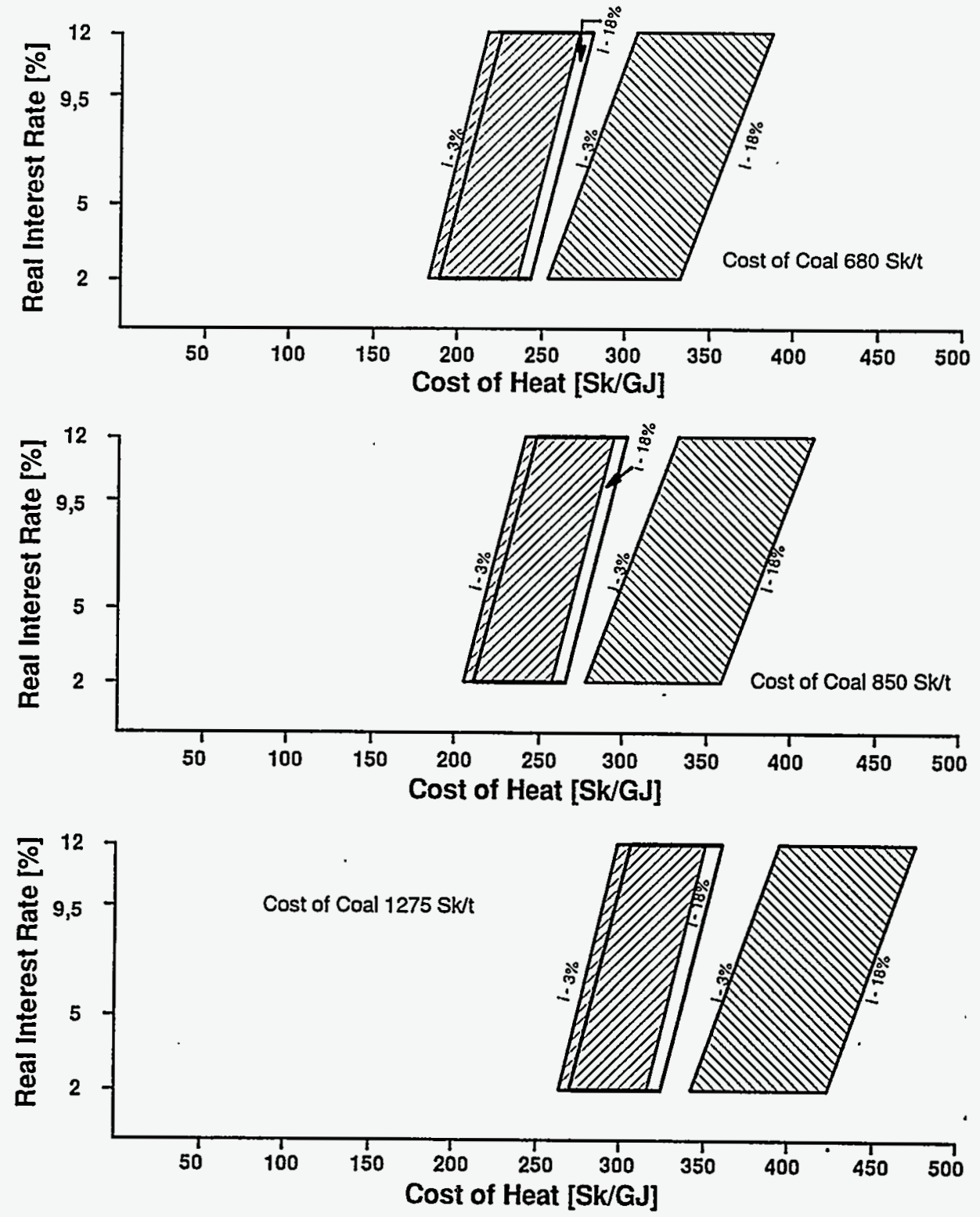

DIVIV Demand Variant 1

Demand Variant 2

DIIIX Demand Variant 3

Figure 3.18 - Cost of Heat as Function of Real Interest and Inflation 
Table 3.6 - Cost of Heat, Alternative 2

\begin{tabular}{|c|c|c|c|c|c|}
\hline $\begin{array}{l}\text { Coal Cost } \\
\text { [Skkt] }\end{array}$ & $\begin{array}{l}\text { Biscount } \\
\text { Rate } \\
\text { Ho] }\end{array}$ & Inflation & 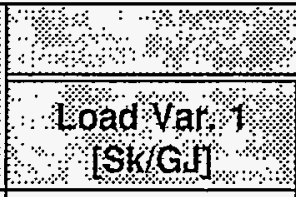 & $\begin{array}{l}\text { Cost of heat } \\
\text { load val } 2 \\
\text { Lskral }\end{array}$ & 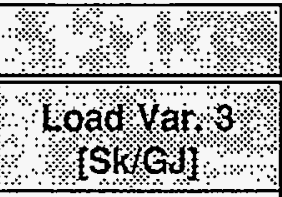 \\
\hline \multirow{4}{*}{467} & 2 & $\begin{array}{c}3 \\
18\end{array}$ & $\begin{array}{l}195,75 \\
265,55\end{array}$ & $\begin{array}{l}130,48 \\
176,35\end{array}$ & $\begin{array}{l}128,75 \\
173,75\end{array}$ \\
\hline & 5 & $\begin{array}{c}3 \\
18\end{array}$ & $\begin{array}{l}209,70 \\
279,50\end{array}$ & $\begin{array}{l}139,65 \\
185,70\end{array}$ & $\begin{array}{l}137,75 \\
183,00\end{array}$ \\
\hline & 9,5 & $\begin{array}{c}3 \\
18\end{array}$ & $\begin{array}{l}230,65 \\
300,50\end{array}$ & $\begin{array}{l}153,40 \\
199,95\end{array}$ & $\begin{array}{l}151,25 \\
197,00\end{array}$ \\
\hline & 12 & $\begin{array}{c}3 \\
18\end{array}$ & $\begin{array}{l}242,20 \\
312,50\end{array}$ & $\begin{array}{l}161,05 \\
207,80\end{array}$ & $\begin{array}{l}158,75 \\
204,75\end{array}$ \\
\hline \multirow{4}{*}{680} & 2 & $\begin{array}{c}3 \\
18\end{array}$ & $\begin{array}{l}236,60 \\
306,40\end{array}$ & $\begin{array}{l}169,08 \\
214,95\end{array}$ & $\begin{array}{l}168,15 \\
213,15\end{array}$ \\
\hline & 5 & $\begin{array}{c}3 \\
18\end{array}$ & $\begin{array}{l}250,60 \\
320,40\end{array}$ & $\begin{array}{l}178,25 \\
224,20\end{array}$ & $\begin{array}{l}190,65 \\
222,15\end{array}$ \\
\hline & 9,5 & $\begin{array}{c}3 \\
18\end{array}$ & $\begin{array}{l}271,50 \\
341,30\end{array}$ & $\begin{array}{l}192,00 \\
238,40\end{array}$ & $\begin{array}{l}205,25 \\
251,25\end{array}$ \\
\hline & 12 & $\begin{array}{c}3 \\
18\end{array}$ & $\begin{array}{l}283,15 \\
253,30\end{array}$ & $\begin{array}{l}199,65 \\
246,35\end{array}$ & $\begin{array}{l}198,15 \\
244,00\end{array}$ \\
\hline \multirow{4}{*}{850} & 2 & $\begin{array}{c}3 \\
18\end{array}$ & $\begin{array}{l}269,25 \\
339,05\end{array}$ & $\begin{array}{l}199,88 \\
245,75\end{array}$ & $\begin{array}{l}199,63 \\
244,60\end{array}$ \\
\hline & 5 & $\begin{array}{c}3 \\
18\end{array}$ & $\begin{array}{l}283,20 \\
353,00\end{array}$ & $\begin{array}{l}209,05 \\
254,95\end{array}$ & $\begin{array}{l}208,63 \\
253,60\end{array}$ \\
\hline & 9,5 & $\begin{array}{c}3 \\
18\end{array}$ & $\begin{array}{l}304,15 \\
373,90\end{array}$ & $\begin{array}{l}222,80 \\
269,20\end{array}$ & $\begin{array}{l}222,10 \\
267,60\end{array}$ \\
\hline & 12 & $\begin{array}{c}3 \\
18\end{array}$ & $\begin{array}{l}315,80 \\
385,80\end{array}$ & $\begin{array}{l}230,45 \\
277,10\end{array}$ & $\begin{array}{l}229,60 \\
275,40\end{array}$ \\
\hline \multirow{4}{*}{1275} & 2 & $\begin{array}{c}3 \\
18\end{array}$ & $\begin{array}{l}350,80 \\
420,60\end{array}$ & $\begin{array}{l}276,90 \\
322,80\end{array}$ & $\begin{array}{l}278,25 \\
323,25\end{array}$ \\
\hline & 5 & $\begin{array}{c}3 \\
18\end{array}$ & $\begin{array}{l}364,75 \\
434,60\end{array}$ & $\begin{array}{l}286,05 \\
331,95\end{array}$ & $\begin{array}{l}287,25 \\
332,25\end{array}$ \\
\hline & 9,5 & $\begin{array}{c}3 \\
18 \\
\end{array}$ & $\begin{array}{l}385,70 \\
455,50\end{array}$ & $\begin{array}{l}299,85 \\
346,00\end{array}$ & $\begin{array}{l}300,75 \\
345,95\end{array}$ \\
\hline & 12 & $\begin{array}{c}3 \\
18\end{array}$ & $\begin{array}{l}397,30 \\
467,20 /\end{array}$ & $\begin{array}{c}307,50 \\
353,95 /\end{array}$ & $\begin{array}{l}308,25 \\
353,70\end{array}$ \\
\hline
\end{tabular}




\section{DECENTRALIZED HEAT SUPPLY SYSTEM}

The analysis presented in this chapter was performed by Stavimex, the Slovak contractor. Presented here are the main highlights of their report. The economic calculations in the Stavimex report were performed without accounting for the time value of money. The cost of servicing the loan was also not considered. In order to compare all analyzed alternatives on an equivalent basis, the economic calculations were performed according to the same model. Therefore, the results presented here are different from those presented in the Stavimex report.

The analysis of the decentralized heat supply were performed for gas fuel only, since previous studies have shown that coal fired environmentally friendly small heat sources (small boilers) cannot compete with gas fired boilers due to the high cost of flue cleaning equipment. Electric boilers were also not considered due to high cost of electric energy. It is expected that the cost of electricity will increase from $1.67 \mathrm{SK} / \mathrm{kWh}$ to approximately $3.0 \mathrm{SK} / \mathrm{kWh}$ in 1997, and up to $3.4 \mathrm{SK} / \mathrm{KWh}$ in 2000.

The analysis assumes that the decentralized heat supply system will provide heat only to residential and non-residential sectors, and will not provide heat to industrial customers. The total installed capacity of all boilers amounts to $42.2 \mathrm{MWt}$ with annual delivery of 377.28 TJ. The assumed total delivered thermal energy is smaller that in previous alternatives, however this should not have any impact on cost of delivered energy. In the case of this system, an increase in the required capacity will equally increase the investment.

\subsection{EQUIPMENT SPECIFICATION}

The specifications for each boiler and other boiler room equipment were based on the required heat delivery in a given location with respect to code CSN 060310 , Section 58b. A duplication of equipment in as many location as possible was also a consideration to simplify maintenance and reduce spare parts inventory. The installation of boilers was assumed (where possible) to be in existing heat exchanger station buildings and existing old boiler houses to minimize the installation cost. The boiler rooms were designed to comply with the code CSN 070703.

\subsubsection{Boiler Rooms}

Following is a description of the proposed equipment in each boiler room and its parameters:

1. Boiler room consisting of:

boiler

condensing units

Total installed output

Number of boiler rooms

$2 \times$ SR plus 602

2x TCR 800

0.7 to $1.24 \mathrm{MWt}$

23 
2. Boiler room consisting of:

boiler

condensing unit

Total installed output

Number of boiler rooms 2x UnoLyt UL 279

$2 \times$ TCR 280

$0.56 \mathrm{MWt}$

18

$2 \times$ AtmoGas 66

$0.132 \mathrm{MWt}$

1

$2 \times$ ST plus 800

$2 \times$ TCR 800

$1.86 \mathrm{MWt}$

3

$3 x$ ST plus 800

$3 \times$ TCR 800

$2.79 \mathrm{MWt}$

3

$3 \times$ ST plus 800

$3 \times$ TCR 800

2.79 MWt

2XTDH PU 400

$800 \mathrm{~kg} / \mathrm{hr}$

BCHP $6.1 \mathrm{~N}$

200-300 kW

1

The total number of Hoval boilers to be installed in all boiler rooms:

Hoval SR plus 620

Hoval ST plus 800

Hoval UnoLyt UL 279

Hoval AtmoGas 66

Hoval THD PU 400
46 pcs

18 pcs

36 pcs

2 pcs

2 pcs

Cogeneration unit

Broadkrown BCHP 280

$1 \mathrm{pc}$

\section{Condensing unit}

Hoval TRC 280

Hoval TRC 800

36 pcs

60 pcs 


\subsubsection{Distribution System}

The distribution system external to the boiler rooms will utilize the existing secondary distribution system. Hot water will be distributed at $110 / 70^{\circ} \mathrm{C}$ in the winter and at $70 / 40^{\circ} \mathrm{C}$ during the summer. Domestic hot water heating and space heating water temperature control will be done in individual residential buildings based on outside air temperature. Buildings will be equipped with GJ meters and water flow meters.

\subsubsection{Water Heating}

The domestic water heating system (DWHS) will be designed in two alternatives, depending on the building:

1. Buildings with the boiler room inside (basement), will have a DWHS with the storage tank installed in the boiler room. The water heating system will utilize the boiler flue gas condensing heat for preheating the cold water.

2. Buildings supplied with heat from an external boiler room (old heat exchanger station) will have the DWHS installed in the external boiler room.

\subsection{Required Investment}

Total installed cost of all listed equipment, including gas piping, and new building structures as required by specification

203,014 thous. SK

Total installed cost for Energy Management System EY 2400 , from Sauter, Switzerland (662,303 SF)

14,570 thous. SK

Installation of gas distribution system for all boiler rooms

11,970 thous. SK

Total Installed Cost of this Alternative

229,554 thous.SK 


\subsection{ANALYSIS OF OPERATION}

Table 4.1 summarizes heat production, consumption of the fuel and electric energy. The construction schedule diagram is shown in Figure 4.1.

\section{Table 4.1 - Operation Data, Alternative 3}

\begin{tabular}{||l|c|c||}
\hline \hline Total Production of Heat by all Boiler Rooms & GJ/year & 377,280 \\
\hline Gas Consumption (33.4 MJ/m3) & $10^{6} \mathrm{m3}$ & $11,074.3$ \\
Internal Consumption & & \\
$\quad$ Thermal Energy & GJ/year &.-- \\
$\quad$ Electricity & MWh/year & 500 \\
Thermal Energy Production & GJ/year & 386,712 \\
Delivered Thermal Energy & GJ/year & 377,280 \\
\hline
\end{tabular}

\subsection{PROJECT ECONOMIC ANALYSIS}

The economic analysis were performed using the discounted cash flow method, the same as in the previous alternatives. 


\section{Boiler Houses}

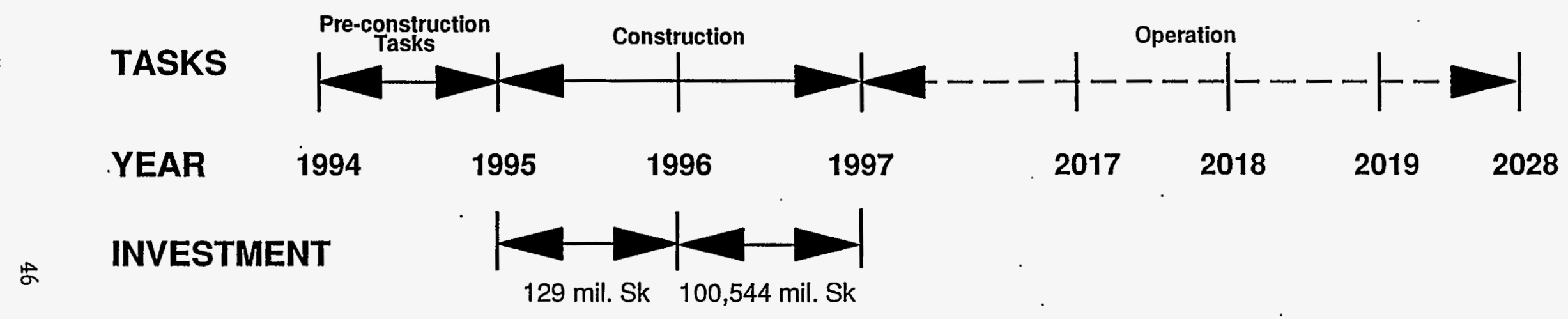

Figure 4.1 - Construction Schedule, Alternative 3 (Decentralized) 
Key Financial Assumptions

Construction duration

Time of Start up/base year

Term of Projected Sales (life)

Cost of Natural Gas in 1997

Gas Cost Escalation

Natural Gas from year 1997 to 2005

after year 2005

Rate of Return of Investment

Nominal Interest Rate

Real Interest Rate

Investment Repayment Term

Investement financed

Net Effective Tax Rate

Labor Rate

Labor Rate Escalation to year 2005

Overhead

Overhead Escalation

Repairs and Maintenance

R\&M Escalation

Material, energy

Water
Water cost escalation

Electricity

Electricity cost escalation

Other expenses, emissions

Other expenses escalation

TOTAL PROJECT COST
2 yearș

1997

25 years

$3,350 \mathrm{SK} / \mathrm{m}^{3}$

$2.85 \%$ annually

$1.4 \%$ annually

$14 \%$

$5 \%$ to $30 \%$

$2 \%, 5 \%, 9.5 \%$ and $12 \%$

10 years

$90 \%$

$45 \%$

$1.8 \mathrm{mil} . \mathrm{SK} / \mathrm{yr}$

$12.4 \%$ annually

$6 \%$ annually

$2.3 \mathrm{mil}$. SK/yr

$7.5 \%$ annually

$3.5 \%$ annually

$2.3 \mathrm{mil}$. SK/yr

to year 2005

$7.5 \%$ annually

$3.5 \%$ annually

to year 2005

after year 2005

a)

b)

a)

b)

$10.0 \mathrm{SK} / \mathrm{m}^{3}$

$2.85 \%$ annually

$1.4 \%$ annually

3,230.0 SK/MWh

1894.0 SK/MWh

$2.0 \%$

$6.0 \%$

.0346 mil SK/yr

$1.0 \%$ annually

229.554 mil. SK

Fuel cost in first year of operation is assumed to be covered from in-house funds. The cost of obtaining the loan is not accounted for and will have to be added to the total cost at the time of detailed financial analyses.

Figure 4.2, Table 4.2 and Table 4.3 present the results of this analysis as function of inflation, delivered energy and the fuel cost. 


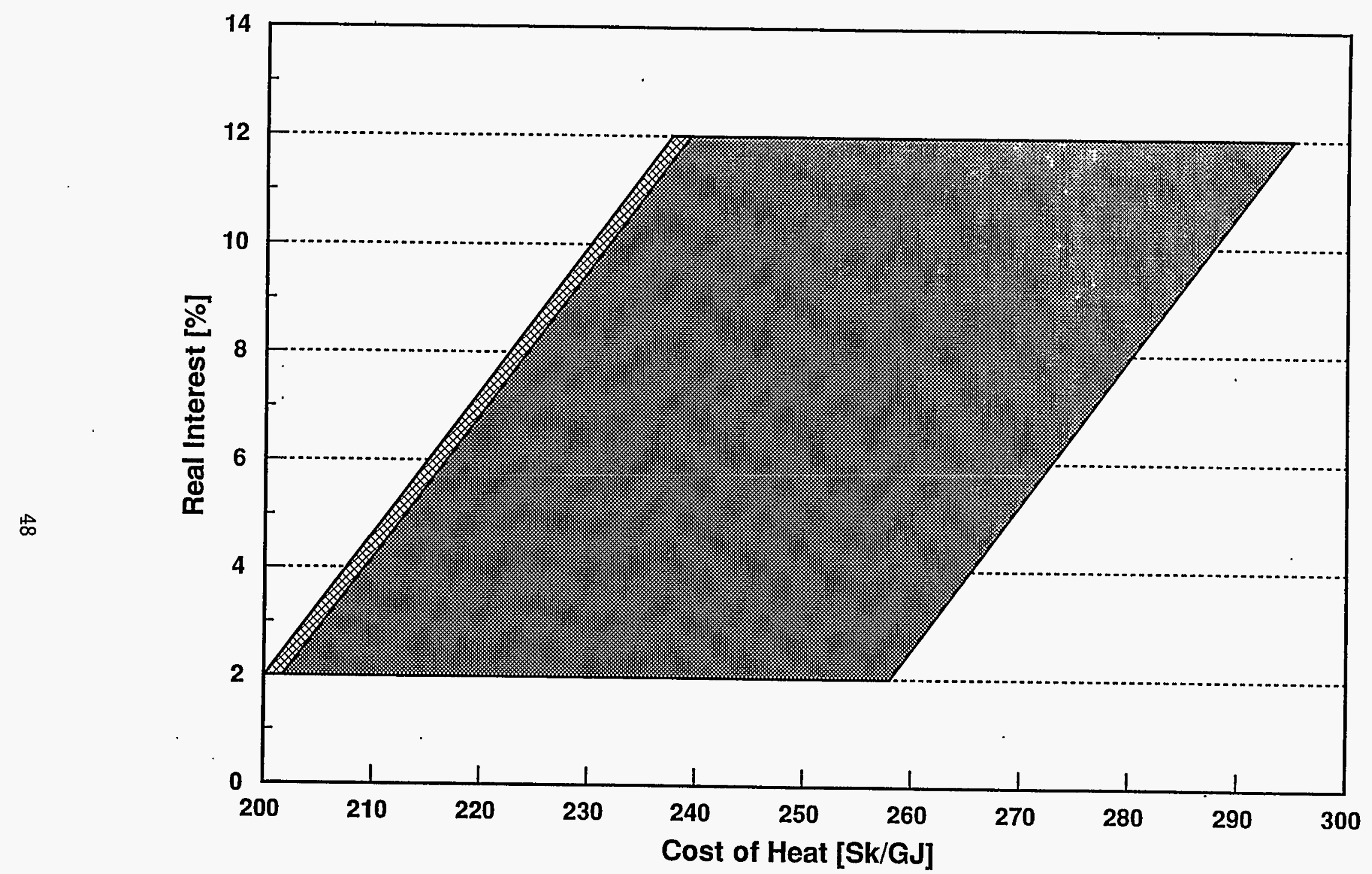

Heat Supply $=377,280 \mathrm{GJ} / \mathrm{yr}$

Cost of Gas $=3.35 \mathrm{SK} / \mathrm{m}^{3}$
Cost of Electricity

1,894 Sk/MWh

ख
3,230 Sk/MWh

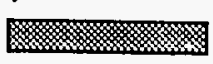

Figure 4.2 - Cost of Heat as Function of Electricity Cost 
Table 4.2 - Results Summary, Alternative 3

\begin{tabular}{|c|c|c|c|}
\hline 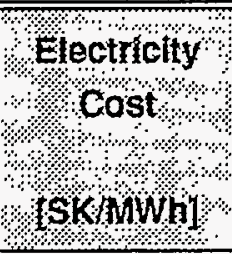 & 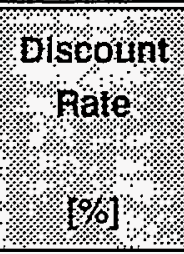 & 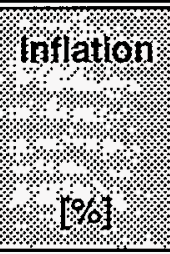 & 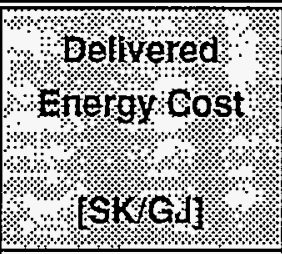 \\
\hline 1894 & $\begin{array}{c}2 \\
5 \\
9.5 \\
12\end{array}$ & $\begin{array}{c}3 \\
18 \\
3 \\
18 \\
3 \\
18 \\
3 \\
18\end{array}$ & $\begin{array}{l}200.75 \\
256.50 \\
211.90 \\
267.60 \\
228.60 \\
284.30 \\
239.90 \\
293.65\end{array}$ \\
\hline 3230 & $\begin{array}{c}2 \\
5 \\
9.5 \\
12\end{array}$ & $\begin{array}{c}3 \\
18 \\
3 \\
18 \\
3 \\
18 \\
3 \\
18\end{array}$ & $\begin{array}{l}201.65 \\
257.40 \\
212.80 \\
268.50 \\
229.50 \\
285.20 \\
238.80 \\
294.60\end{array}$ \\
\hline
\end{tabular}




\section{COMPARISON OF ALTERNATIVES}

This chapter summarizes the results and offers a comparison of the results obtained for all three alternatives. The results are shown in Table 5.1. The economic parameters for the central district heat system shown in this table were, for the purpose of comparison, calculated for load Variant 2 and a coal cost of 680 SK/ton, which is the most likely cost of coal in year 1997.

As it can be seen from the presented results, that lowest delivered energy cost $(205.80$ SKJGJ) is for Alternative 2. Alternative 2 also creates approximately 55 job opportunities and helps to maintain 1,000 to 1,400 jobs in the Handlova Coal Mine. (Note that the central heating system may not be the only user of the industrial grade coal produced by the coal mine, and the coal mine can maintain employment by finding other customers, should the heating system be converted to natural gas.) The delivered energy cost for Alternative 1 is slightly higher - 228.35 Sk/GJ, however, this Alternative offers more reliable operations, lower emissions and less solid waste production due to bi-fuel (coal/gas) base.

In order to compare the town's central and decentralized energy supply system options on an equal platform, the economic calculations were performed for selected technical and economic assumptions which were the same for both systems. Internal Rate of Return on investment was set at $14 \%$, financing of the project was assumed to be $90 \%$, electricity price sold to distribution was assumed to be 1,389 SK/MWh and cost of electricity purchased was assumed at 1,894 SK/MWh. The central system is represented by Alternative 1. The delivered thermal energy cost was selected as the comparison parameter. The results are graphically presented in Figure 5.1. The five fields shown in the Figure 5.1 represent delivered energy cost ranges calculated for Alternative 1 and 3.

Each field is defined by the minimum assumed fuel price (467 SK/ton for coal) and minimum . inflation (3\%) on the left side and the maximum assumed fuel price ( $1,275 \mathrm{SK} /$ ton for coal) and maximum inflation (18\%) on the right side. The price of natural gas is assumed to be $3,350 \mathrm{Sk} / \mathrm{m}^{3}$. The real interest rate of $2 \%$ and $12 \%$ defined the low and high of the range, respectively.

The following conclusions can be drawn from the presented results of comparison of the central and the decentralized heating systems, providing that the fuel prices and the prices of electricity purchased and sold will be developing as assumed in the calculation:

- The delivered energy cost will be lower for the decentralized system when the coal price is higher than $800 \mathrm{SK} /$ ton and the thermal energy demand is lower than 350 $\mathrm{TJ} /$ year. Increased demand and lower coal price will make the centralized system more attractive.

- The delivered energy cost will be lower for the central heating system when the coal price is less than $700 \mathrm{SK} /$ ton and the thermal energy demand is over $500 \mathrm{TJ} / \mathrm{year}$. 
Coal Cost $=467$ Sk/ton to 1275 Sk/ton Gas Cost $=3.35 \mathrm{sk} / \mathrm{m}^{3}$

Cost of Electricity:

Sale - 1389 Sk/MWh

Purchase - 1894 to 3230 Sk/MWh

Financing $=90 \%$

Inflation $=3$ to $.18 \%$

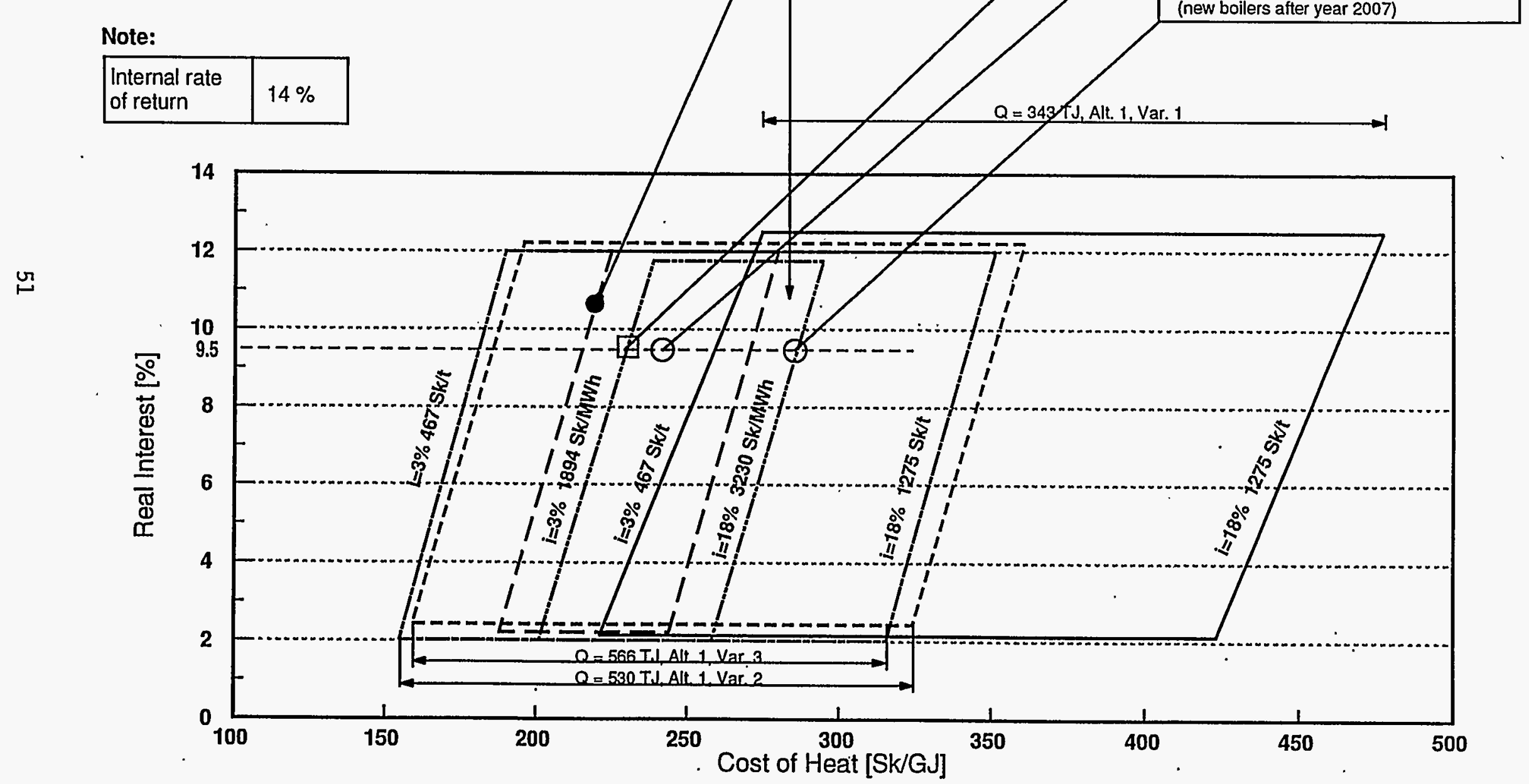

Figure 5.1 - Economic Analysis and Sensitivity of Results for Decentralized (Alt. 3) and Central (Alt. 1) Production of Thermal Energy for Space and Water Heating in the Town of Handlova, Slovakia 
The absolute delivered energy cost will depend on the actual economic parameters, such . as general inflation, real interest rate, purchasing and selling prices of electricity, and on actual thermal energy demand. The thermal delivered energy cost fields shown in Figure 5.1 are overlapping and suggest the thermal delivered energy price could fall in broad range from approximately 150 to 430 SK/GJ: A more realistic range is more likely to be between 200 and 250 SK/GJ.

In the US it is common practice to perform the economic analysis on a real basis, thus excluding general inflation. Such analysis can be performed under the assumption that the inflation has the same impact on general prices and income of citizens. This is currently not the case in Slovakia, where prices are inflating at a substantially higher rate than income. For this reason, the general inflation impact was considered in this analysis. The effect of the general inflation can be removed by setting the inflation rate equal to zero. In this case, the delivered energy cost would in general be lower.

The decision on whether to implement the decentralized or the central heat supply system will depend on actual negotiated prices of coal from the Handlova Coal Mine, the latest development in world gas prices and the latest estimates for the purchase and selling price of electricity.

The economic calculations were performed with the following assumptions: $90 \%$ financing, real interest rate $9.5 \%$, nominal interest rate $17 \%$, coal price (1st year of operation) $680 \mathrm{SK} /$ ton, gas price $3.25 \mathrm{SK} / \mathrm{m}^{3}$, electricity purchase price (selling to distribution) $1,894 \mathrm{SK} / \mathrm{MWh}$, electricity cost (buy from distribution) 1,389 SK/MWh, and required return on investment $14 \%$. 
Table 5.1 - Technical and Economical Comparison of Alternatives

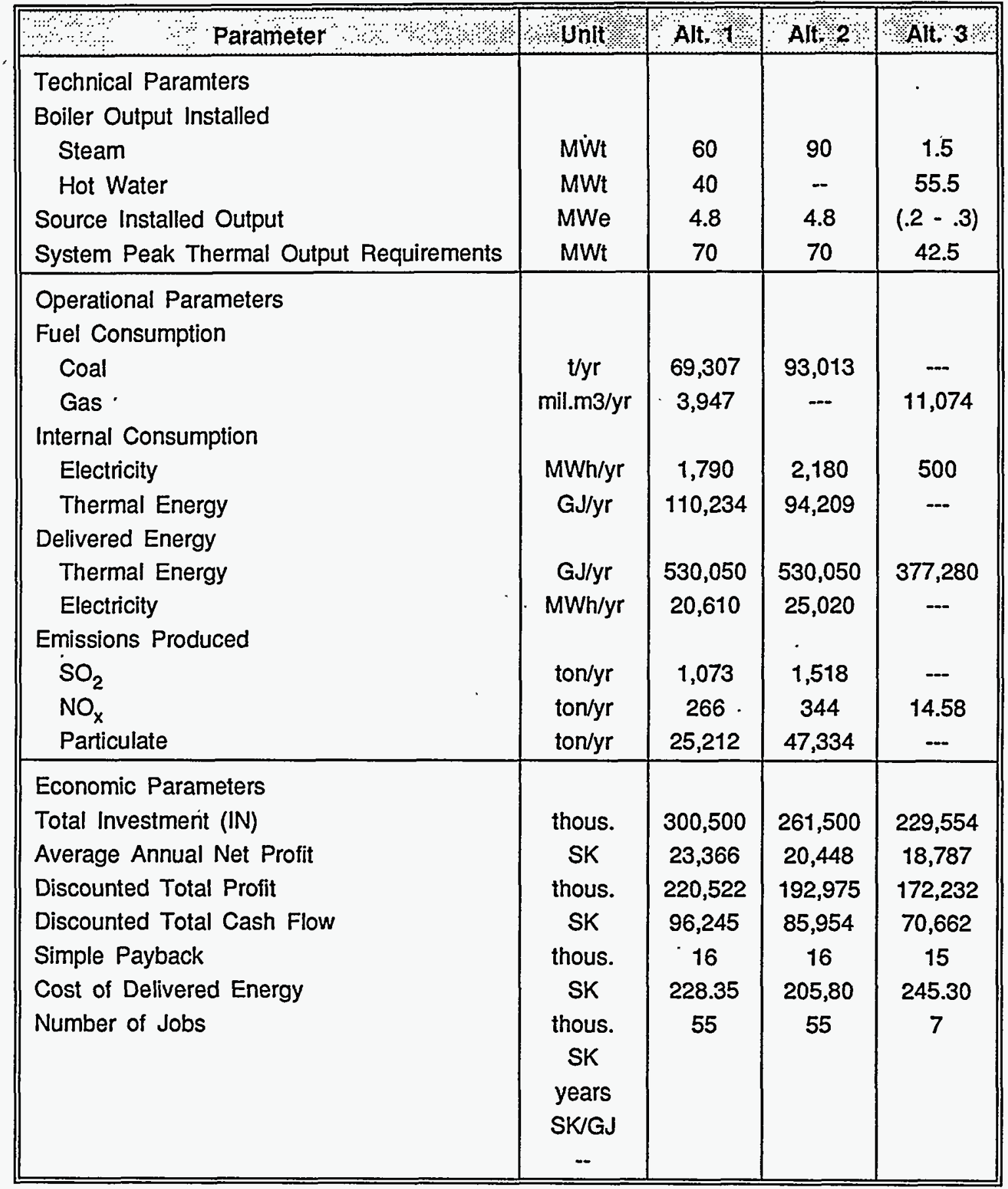




\section{REFERENCES}

Pouzité podklady

EGÚ Bratislava

s.p.

EGÚ Bratislava

s.p.

INKA-P Nitra

s.r.o.

INCO Bratislava

a.s.

a EGÚ Bratislava

s.p.

SAVE Žilina

s.r.o.

SAVE Žilina

s.r.o.

Energoprojekt

Kosice s.p.

Kovoprojekt

Presov s.p.

EMMEL Presov
" Kotol s tlakovým fluidným spalovaním ", august 1991

" Prepočet efektívnosti variantných projektov inovacie zdroja EHA a rozvodnej siete ", september 1991

" Ponuka na vypracovanie projektu a dodavok nových zdrojov tepla v meste Handlova ", februar 1993

" Navrh na riesenie teplofikacie mesta Handlova " odborna pomoc; jún 1993

" Výpočet tepelných strat v sek.rozvodoch ÚK z VS 1 a VS 5 ", maj 1993

" Výpočet tepelných strat v primarnej tepelnej siete ", maj 1993

" Handlova-stúdia prechodu z parných sietí CZT na jorúcovodne" marec 1992

" Výpočet stabilitných pomerov zloziska popolčeka" apríl 1991

" Skladka popolčeka a skvary" maj 1991 


\section{APPENDIX A}

Al 

Table A1 - Cash Flow S

\begin{tabular}{|c|c|c|c|c|c|c|c|c|c|c|c|}
\hline & \multicolumn{11}{|c|}{. } \\
\hline Heat [TJ] & & & 518.9 & $5 t 9.3$ & 519.8 & 520.3 & 520.8 & 521.2 & 521.7 & 5222 & 5227 \\
\hline Escalatod prico [SKGG] & & & 228.4 & 233.7 & 239.0 & 244.5 & 250.1 & 255.9 & 261.8 & 267.8 & 274.0 \\
\hline Eloctricity supply [GWh] & & & 19.9 & 19.9 & 19.9 & 20 & 20 & 20 & 20.1 & 20.1 & 20.1 \\
\hline Escalated price [SKMMWh] & & & 1389.0 & 1472.3 & 1560.7 & 1654.3 & 1753.6 & 1858.8 & 1970.3 & 2088.5 & 2213.9 \\
\hline \multicolumn{12}{|l|}{ Cost of Fud and Energy } \\
\hline Coal consumption [tons] & & & 68491.4 & 68525.1 & 68588.9 & 685027 & $68 \approx 26.5$ & 68660.4 & 68094.2 & 68728.1 & 68762 \\
\hline Escalated cost $\alpha \cos$ [SKton] & & & 680 & 698.4 & 717.2 & 736.6 & 756.5 & 776.9 & 797.9 & 819.4 & 841.5 \\
\hline Gas.consumption [ths.m3] & & & 3945.5 & 3945.5 & 3945.5 & 3945.6 & 3945.6 & 3945.7 & 3945.7 & 3945.8 & 3945.8 \\
\hline Escilatod prico [SLinh.m3] & & & 3350.0 & 3445.5 & 3543.7 & 3644.7 & 3748.5 & 3855.4 & 3965.3 & 4078.3 & 4194.5 \\
\hline Labor and overhead [thous. SK] & & & 8750.0 & 9835.0 & 11054.5 & 12425.3 & 13966.0 & $15 \vdots 7.8$ & 17644.4 & 198323 & 22291.5 \\
\hline Repair and Maint. [thous. SK] & & & 5000 & 5375.0 & 5778.1 & 6211.5 & 6677.3 & 7178.1 & 7716.5 & 8295.2 & 8917.4 \\
\hline Emissions [thous. SK] & & & 2359.7 & 2384.4 & 2409.4 & 2434.7 & 2460.2 & 2486.0 & 2512.0 & 2538.3 & 2564.9 \\
\hline Matorials, tueis [thous. SK] & & & 3500 & $37 \approx .5$ & 4044.7 & 4348.0 & 4674.1 & 5024.7 & 5401.6 & 5806.7 & 6242.2 \\
\hline Oremead (thous. SK] & & & 3000 & 3180.0 & 3370.8 & 3573.0 & 3787.4 & 4014.7 & 4255.6 & 4510.9 & 4781.5 \\
\hline Depreciat, exist assseis [th. SK] & & & 1556 & 1556 & 1556 & 690 & 690 & 690 & 690 & 690 & 690 \\
\hline \multicolumn{12}{|l|}{ Project Summary } \\
\hline Depreciation & 0 & 0 & 13787 & 13787 & 13787 & 13787 & 13787 & 13787 & 13787 & 13787 & 13787 \\
\hline Anrual Interest & 0 & 0 & 22735 & 22735 & 22735 & 22735 & 22735 & 22735 & 22735 & 22735 & 22735 \\
\hline Investment Tota & 150250 & 150250 & 0 & of & 0 & 0 & o & 0 & 0 & 0 & $\underline{0}$ \\
\hline \multicolumn{12}{|l|}{ Fines } \\
\hline Prodit & 0 & 0 & 27176 & 28130 & 29017 & 29822 & 30531 & $3+125$ & 31583 & 31880 & 31992 \\
\hline Cash Fow Projoct & .150250 & .150250 & 63698 & 64652 & 65538 & 66344 & 67053 & 67647 & 68104 & 68402 & 68513 \\
\hline Cash Flow, m.t & .164524 & -150250 & 58172 & 53920 & 49918 & 46147 & 42594 & 39243 & 36081 & 33095 & 30273 \\
\hline Discountod Cash Flow, Project & -164524 & .314774 & -256602 & -202682 & -152764 & .105617 & .64023 & -24780 & 11301 & 44395 & 74668 \\
\hline \multicolumn{12}{|l|}{ Investors Summary } \\
\hline Depreciation & 0 & 0 & 14779 & 14778 & 14779 & 14779 & 14779 & 14779 & 14779 & 14779 & 14779 \\
\hline Depreciation of Existing Equip. & 0 & 0 & 1556 & 1556 & 1556 & 690 & 690 & 690 & 690 & 690 & 690 \\
\hline Interest & 22388 & 45977 & 41379 & 36781 & 32184 & 27586 & 22988 & 18391 & 13793 & S195 & 4598 \\
\hline Interest During Construction & 22988 & 45977 & 0 & 0 & 0 & 0 & 0 & 0 & 0 & of & 0 \\
\hline Pro-Tax Profit & 0 & 0 & 5985 & 11536 & 17020 & 23290 & 28596 & 33787 & 38843 & 43738 & 48447 \\
\hline Taxes & 0 & 0 & 2690 & 5181 & 7659 & 10480 & 12868 & 15204 & 17479 & 19682 & 21801 \\
\hline Usable Profit & 0 & 0 & 3292 & 6345 & 9361 & 12809 & 15728 & 18583 & 21364 & 24056 & 25646 \\
\hline Orn Investment & 15025 & 15025 & 0 & 0 & 0 & 으 & 0 & 0 & 0 & 0 & 0 \\
\hline Loan Draw.Down & 135225 & 135225 & 0 & 0 & of & 0 & 0) & 0 & 0 & of & 0 \\
\hline Subsidies & 요 & of & 0 & 0 & 요 & 0 & 0 & 0 & ol & 0 & 0 \\
\hline Loan Paymont & 0 & 0 & 27045 & 27045 & 27045 & 27045 & 27045 & 27045 & 27045 & 27045 & 27045 \\
\hline Cash Flow (after tax) & .38013 & .61002 & -7419 & -4366 & .1340 & 1233 & 4152 & 7007 & 9787 & 12480 & 15070 \\
\hline Cash Flow, $r^{\mathrm{A}} \mathrm{l}$ & .41625 & -61002 & .6775 & -3641 & .1028 & 858 & 2637 & 4055 & 5185 & 6038 & 6658 \\
\hline Discounlad Cash Flow. Investor & .41625 & .102626 & .109401 & .113042 & -114070 & .113212 & $.110575 !$ & .105510 & .101325 & .95287 & .88629 \\
\hline
\end{tabular}


nmary, Alternative 1, Load Variant 2

\begin{tabular}{|c|c|c|c|c|c|c|c|c|c|c|c|c|c|c|c|}
\hline \multicolumn{16}{|c|}{ Year } \\
\hline 2006 & 2007 & 2008 & 2009 & 2010 & 2011 & 2012 & 2013 & 2014 & 2015 & 2016 & 2017 & 2018 & 2019 & 2020 & 2021 \\
\hline 523.2 & 523.7 & 524.2 & 524.6 & 525.1 & 525.6 & 526.1 & 526.6 & 527.1 & 527.6 & 528.1 & 528.6 & 529 & 529.5 & 530 & 530.5 \\
\hline 280.3 & 286.7 & 293.3 & 300.1 & 307.0 & 314.0 & 321.2 & 328.6 & 336.2 & 343.9 & 351.8 & 359.9 & 368.2 & 376.7 & 385.3 & 394.2 \\
\hline 20.2 & 20.2 & 20.2 & 20.2 & 20.3 & 20.3 & 20.3 & 20.4 & 20.4 & 20.4 & 20.5 & 20.5 & 20.5 & 20.5 & 20.6 & 20.6 \\
\hline 2346.7 & 2487.5 & 2636.7 & 2794.9 & 29026 & 3140.4 & 3328.8 & 3528.5 & 3740.3 & 3964.7 & 42026 & 4454.7 & 47220 & 5005.3 & 5305.6 & 5624.0 \\
\hline & & & & & & & & & & & & & & & \\
\hline 8795.9 & 68829.8 & 68863.8 & 68897.7 & 68931.7 & 68965.7 & 68999.7 & 69033.7 & 69067.3 & 69101.8 & 69135.9 & 69170 & 69204.1 & 69238.2 & 692724 & 69306.8 \\
\hline 864.3 & 887.6 & $\$ 11.6$ & 936.2 & 961.4 & 987.4 & 1014.1 & 1041.4 & 1069.5 & 1058.4 & 1128.1 & 1158.6 & 1189.8 & 12220 & 1255.0 & 1288.8 \\
\hline 3945.9 & 3945.9 & 3946 & 3946 & 3946.1 & 3946.1 & 3946.2 & 3946.2 & 3946.3 & 3946.3 & 3946.4 & 3946.4 & 3946.5 & 3946.5 & 3946.6 & 3946.7 \\
\hline 4253.2 & 43128 & 4373.1 & 4434.4 & 4496.4 & 4559.4 & 4623.2 & 4687.9 & 4753.5 & 4820.1 & 4887.6 & 4956.0 & 5025.4 & 5095.8 & 5167.1 & 5239.5 \\
\hline & & & & & & & & & & & & & & & $\cdot$ \\
\hline $3 \approx 2.9$ & 25046.7 & 26549.5 & 281425 & 29831.0 & $31 \approx 20.9$ & 33518.1 & 35529.2 & 37661.0 & 39920.6 & 42315.8 & 44854.8 & 47546.1 & 50398.9 & 534228 & $56 \approx 28.2$ \\
\hline 9229.5 & 9552.5 & 9885.9 & 102329 & 10591.1 & 10961.7 & 11345.4 & 117425 & 12153.5 & 12578.9 & 13019.1 & 13474.8 & 13946.4 & 14434.5 & 14939.7 & 154626 \\
\hline 2591.8 & 2619.0 & 2646.4 & 2674.2 & 2702.2 & 2730.5 & 2759.1 & 2788.0 & 2817.3 & 2846.8 & 2876.6 & 2906.8 & 2937.2 & 2968.0 & 2999.1 & 3030.6 \\
\hline 6460.6 & 6686.8 & 6920.8 & 710.0 & 7413.7 & 7673.2 & 7941.8 & 8219.7 & 8507.4 & .8805 .2 & 9113.4 & 9432.4 & $97 £ .5$ & 10404.2 & 10457.8 & 10823.8 \\
\hline 4925.0 & 5072.7 & 5224.9 & 5381.7 & 5543.1 & 5709.4 & 5880.7 & 6057.1 & 6238.3 & 6426.0 & 6618.8 & 6817.3 & 7021.9 & 7232.5 & 7449.5 & 7673.0 \\
\hline 690 & 690 & 690 & 690 & 690 & 690 & 690 & 690 & 690 & 690 & 690 & 690 & 690 & 690 & 690 & 690 \\
\hline & & & & & & & & & & & & & & & \\
\hline 13787 & 13787 & 13787 & 13787 & 13787 & 13787 & 13787 & 13787 & 13787 & 13787 & 13787 & 13787 & 13787 & 13787 & 13787 & 13787 \\
\hline 22735 & 22735 & 22735 & 22735 & 22735 & 22735 & 22735 & 22735 & 22735 & 22735 & 22735 & 22735 & 22735 & 22735 & 22735 & 22735 \\
\hline 0 & 0 & 0 & 0 & 0 & 0 & 0 & 0 & 0 & 0 & 0 & 0 & 0 & 0 & 0 & 0 \\
\hline 34302 & 36713 & 39230 & 41860 & 44607 & 47479 & 50483 & $53 \approx 26$ & 56918 & 60362 & 63973 & 67757 & 71725 & 75888 & 80256 & 84842 \\
\hline 70824 & 73235 & 75752 & 78381 & 81128 & 84001 & 87005 & 90148 & 93438 & 96884 & 100494 & 104279 & 108247 & 112410 & 116778 & 121364 \\
\hline 28578 & 26988 & 25493 & 24090 & 22771 & 21531 & 20366 & 19272 & 18242 & 17274 & 16363 & 15506 & 14700 & 13941 & 13226 & 12553 \\
\hline 103246 & 130234 & 155727 & 179817 & 202587 & 224119 & 244485 & 263757 & 281959 & 229272 & 315635 & 331141 & 345841 & 359781 & 373007 & 385560 \\
\hline & & & & & . & & & & & & & & & & \\
\hline & & & & & & & & $:$ & & & & & & & \\
\hline 14779 & 14779 & 14779 & 14779 & 14779 & 14779 & 14779 & 14779 & 14779 & 14778 & 14779 & 14779 & 14779 & 14779 & 14779 & 14779 \\
\hline 690 & 690 & 690 & 690 & 690 & 690 & 690 & 690 & 650 & 690 & 690 & 890 & 690 & 690 & 690 & 680 \\
\hline 0 & 0 & 0 & 0 & 0 & 0 & 0 & 0 & 0 & 0 & 0 & 0 & 0 & 0 & 0 & 0 \\
\hline 0 & 0 & 0 & 0 & 0 & 0 & 0 & 0 & 0 & 0 & 0 & 0 & 0 & 0 & 0 & 0 \\
\hline 55355 & 57766 & 60283 & 62913 & 65660 & 68532 & 71536 & 74679 & 77970 & 81416 & 85026 & 88810 & 92778 & 96941 & 101309 & 105896 \\
\hline 24910 & 25995 & 27128 & 28311 & 29547 & 30840 & 32191 & 33606 & 35086 & $36 \varpi 7$ & 38262 & 39965 & 41750 & 43623 & 45589 & 47653 \\
\hline 30445 & 31772 & 33156 & 34602 & 36113 & 37693 & 39345 & 41074 & 42883 & 44779 & 46764 & 48846 & 51028 & 53318 & 55720 & 58243 \\
\hline 0 & 0 & 0 & 0 & 0 & 0 & 0 & 0 & 0 & 0 & 0 & 0 & 0 & 0 & 0 & 0 \\
\hline 0 & 0 & 0 & 0 & 0 & 0 & 0 & 0 & 0 & 0 & 0 & 0 & 0 & 0 & 0 & 0 \\
\hline 0 & 0 & 0 & 0 & 0 & 0 & 0 & 0 & 0 & 0 & 0 & 0 & 0 & 0 & 0 & 0 \\
\hline 27045 & 0 & 0 & 0 & 0 & 0 & 0 & 0 & 0 & 0 & 0 & 0 & 0 & 0 & 0 & 요 \\
\hline 18869 & 47240 & $48 \sigma 24$ & 50071 & 51582 & 53161 & 54813 & 56542 & 58352 & 60247 & 62233 & 64314 & 66-496 & 68786 & 71180 & 73711 \\
\hline 7614 & 17408 & 16364 & 15389 & 14478 & 13626 & 12831 & 12087 & 11392 & 10742 & 10133 & 8563 & 9030 & 8531 & 8063 & 7624 \\
\hline 81015 & .63607 & $.47243 !$ & -31854 & .17377 & .3750 & 9081 & 21168 & 32500 & 43302 & 53345 ! & 62998 & 72028 & 80559 & 88621 & 96245 \\
\hline
\end{tabular}




\section{PARAMETERS OF ECONOMIC EFFECTIVENESS}

ALTERNATIVE 1

\section{Table A.2 - Heat Supply According to Variant 1}

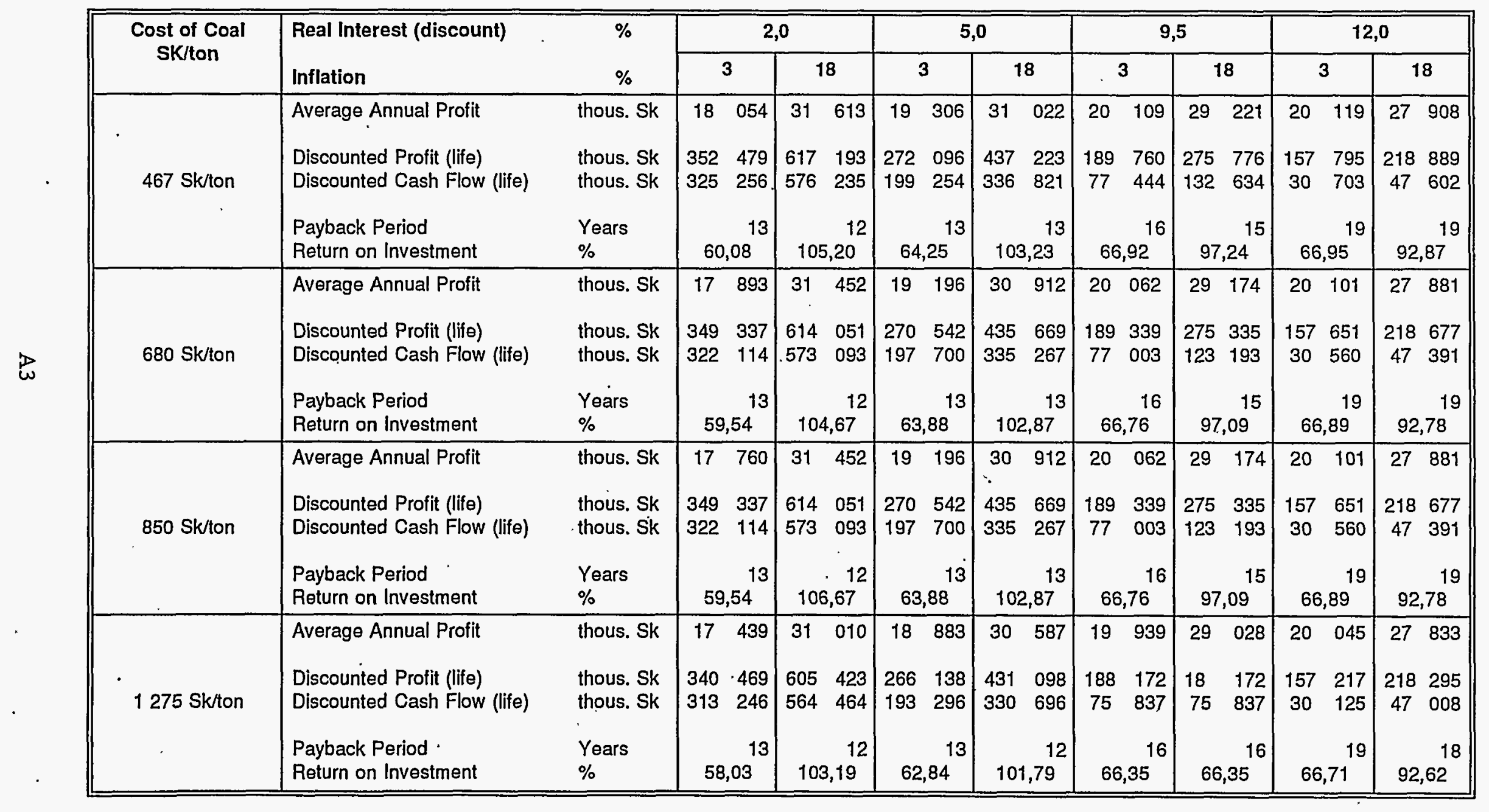


PARAMETERS OF ECONOMIC EFFECTIVENESS

ALTERNATIVE 1

Table A.2 - Heat Supply According to Variant 2

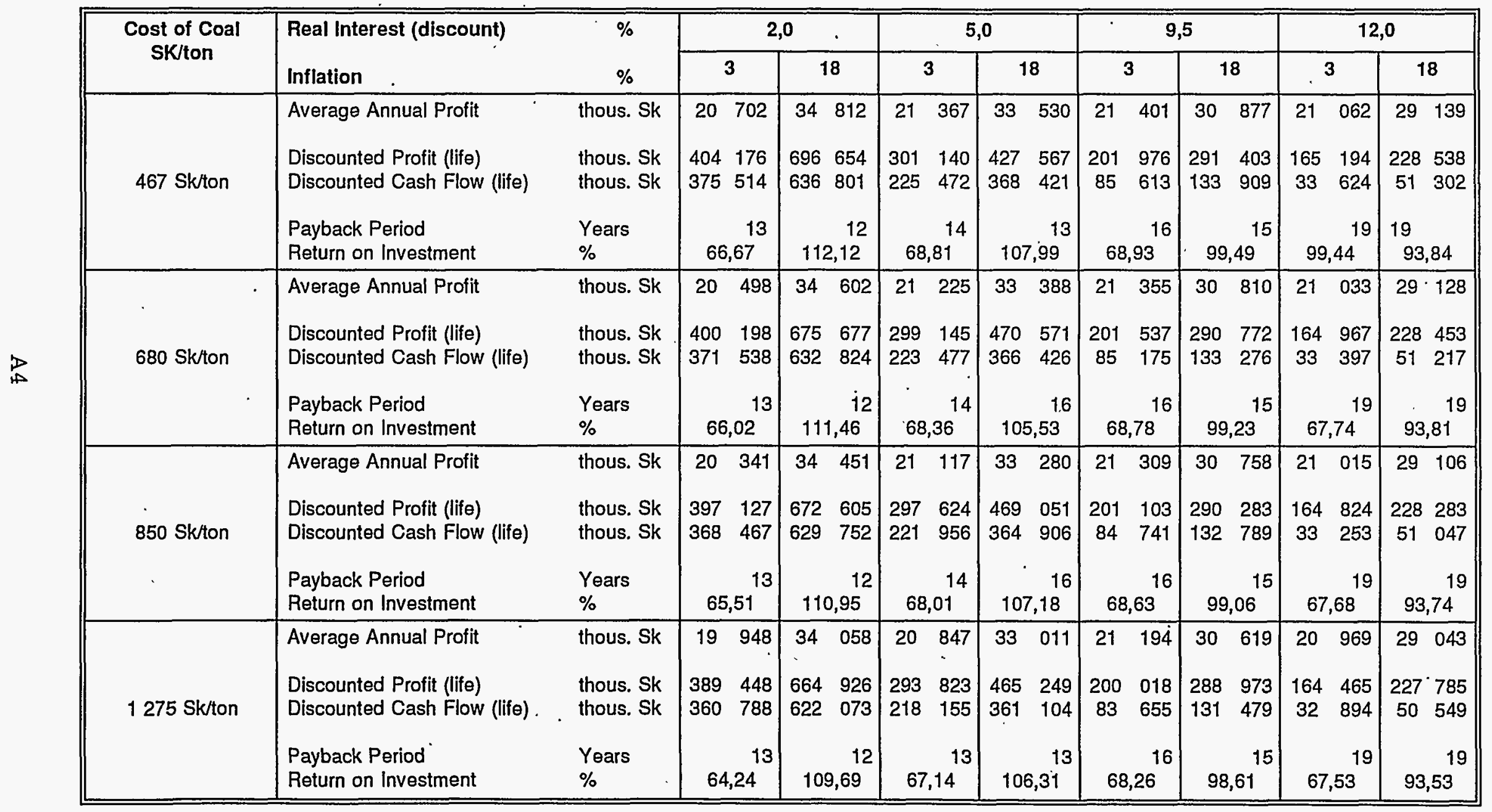


PARAMETERS OF ECONOMIC EFFECTIVENESS

ALTERNATIVE 1

Table A.2 - Heat Supply According to Variant 3

\begin{tabular}{|c|c|c|c|c|c|c|c|c|c|c|}
\hline \multirow{2}{*}{$\begin{array}{c}\text { Cost of Coal } \\
\text { SK/ton }\end{array}$} & \multirow{2}{*}{$\begin{array}{l}\text { Real Interest (discount) } \\
\text { Inflation }\end{array}$} & \multirow{2}{*}{$\begin{array}{l}\% \\
\%\end{array}$} & \multicolumn{2}{|c|}{2,0} & \multicolumn{2}{|c|}{5,0} & \multicolumn{2}{|c|}{9,5} & \multicolumn{2}{|c|}{12,0} \\
\hline & & & 3 & 18 & 3 & 18 & 3 & 18 & 3 & 18 \\
\hline 467 Sk/ton & $\begin{array}{l}\text { Average Annual Profit } \\
\text { Discounted Profit (life) } \\
\text { Discounfed Cash Flow (life) } \\
\text { Payback Period } \\
\text { Return on Investment }\end{array}$ & $\begin{array}{l}\text { thous. Sk } \\
\text { thous. Sk } \\
\text { thous. Sk } \\
\text { Years } \\
\%\end{array}$ & $\begin{array}{cc}20 & 461 \\
& \\
399 & 461 \\
372 & 239 \\
& \\
& 13 \\
68,09\end{array}$ & $\begin{array}{cc}34 & 408 \\
671 & 772 \\
630 & 813 \\
& \\
& 12 \\
114,50\end{array}$ & $\begin{array}{cc}20 & 989 \\
& \\
295 & 812 \\
222 & 970 \\
& \\
& 14 \\
114,50\end{array}$ & $\begin{array}{cc}32 & 992 \\
& \\
464 & 994 \\
364 & 592 \\
& \\
& 13 \\
109,79\end{array}$ & $\begin{array}{cc}20 & 781 \\
196 & 974 \\
84 & 638 \\
& \\
& 16 \\
69,45\end{array}$ & $\begin{array}{cc}30 & 150 \\
& \\
284 & 547 \\
132 & 405 \\
& 16 \\
& 16 \\
100,33\end{array}$ & $\begin{array}{cc}20 & 428 \\
& \\
160 & 221 \\
33 & 129 \\
& 19 \\
& 19 \\
67,98\end{array}$ & $\begin{array}{cc}28 & 306 \\
222 & 005 \\
50 & 718 \\
& 19 \\
& 19\end{array}$ \\
\hline $680 \mathrm{Sk} / \mathrm{ton}$ & $\begin{array}{l}\text { Average Annual Profit } \\
\text { Discounted Profit (life) } \\
\text { Discounted Cash Flow (life) } \\
\text { Payback Period } \\
\text { Return on Investment }\end{array}$ & $\begin{array}{l}\text { thous. Sk } \\
\text { thous. Sk } \\
\text { thous. Sk } \\
\text { Years } \\
\%\end{array}$ & $\begin{array}{cc}20 & 322 \\
& \\
396 & 761 \\
369 & 539 \\
& \\
& 13 \\
67,63\end{array}$ & $\begin{array}{cc}34 & 262 \\
& \\
668 & 920 \\
627 & 962 \\
& \\
& 12 \\
114,02\end{array}$ & $\begin{array}{cc}20 & 904 \\
& \\
294 & 616 \\
221 & 774 \\
& \\
& 14 \\
69,56\end{array}$ & $\begin{array}{cc}32 & 896 \\
463 & 631 \\
363 & 229 \\
& 13 \\
109,47\end{array}$ & $\begin{array}{cc}20 & 821 \\
196 & 498 \\
84 & 163 \\
& 16 \\
& 16 \\
69,29\end{array}$ & $\begin{array}{cc}30 & 091 \\
& \\
283 & 985 \\
131 & 843 \\
& 16 \\
100,14\end{array}$ & $\begin{array}{cc}20 & 419 \\
160 & 147 \\
33 & 055 \\
& 19 \\
67,95\end{array}$ & $\begin{array}{cc}28 & 290 \\
& \\
221 & 885 \\
50 & 599 \\
& \\
& 19 \\
94,14\end{array}$ \\
\hline 850 Sk/ton & $\begin{array}{l}\text { Average Annual Profit } \\
\text { Discounted Profit (life) } \\
\text { Discounted Cash Flow (life) } \\
\text { Payback Period } \\
\text { Return on Investment }\end{array}$ & $\begin{array}{l}\text { thous. Sk } \\
\text { thous. Sk } \\
\text { thous. Sk } \\
\text { Years } \\
\%\end{array}$ & $\begin{array}{cc}20 & 223 \\
394 & 816 \\
367 & 593 \\
& \\
& 13 \\
67,30\end{array}$ & $\begin{array}{cc}34 & 171 \\
667 & 126 \\
626 & 168 \\
& \\
& 12 \\
113,71\end{array}$ & $\begin{array}{cc}20 & 826 \\
293 & 523 \\
220 & 681 \\
& \\
& 14 \\
69,31 & \end{array}$ & $\begin{array}{cc}32 & 804 \\
462 & 344 \\
361 & 942 \\
& 13 \\
109,17\end{array}$ & $\begin{array}{cc}20 & 803 \\
196 & 331 \\
83 & 996 \\
& 16 \\
& 16 \\
69,23\end{array}$ & $\begin{array}{cc}30 & 064 \\
& \\
283 & 728 \\
131 & 585 \\
& \\
100,05 & 16\end{array}$ & $\begin{array}{cc}20 & 402 \\
160 & 017 \\
32 & 925 \\
& 19 \\
67,89 & \end{array}$ & $\begin{array}{cc}28 & 265 \\
& \\
221 & 684 \\
50 & 397 \\
& \\
& 19 \\
94,06\end{array}$ \\
\hline 1275 Sk/ton & $\begin{array}{l}\text { Average Annual Profit } \\
\text { Discounted Profit (life) } \\
\text { Discounted Cash Flow (life) } \\
\text { Payback Period } \\
\text { Return on Investment }\end{array}$ & $\begin{array}{l}\text { thous. Sk } \\
\text { thous. Sk } \\
\text { thous. Sk } \\
\text { Years } \\
\%\end{array}$ & $\begin{array}{cc}19 & 952 \\
389 & 536 \\
362 & 313 \\
& 13 \\
& 13 \\
66,40\end{array}$ & $\begin{array}{cc}33 & 892 \\
& \\
661 & 695 \\
620 & 736 \\
& \\
& 12 \\
112,79\end{array}$ & $\begin{array}{cc}20 & 651 \\
291 & 055 \\
218 & 213 \\
& 14 \\
& 14 \\
68,72\end{array}$ & \begin{tabular}{cc|}
32 & 618 \\
459 & 719 \\
359 & 317 \\
& 13 \\
108,55
\end{tabular} & $\begin{array}{cc}20 & 715 \\
195 & 496 \\
83 & 160 \\
& \\
& \\
& \\
68,93 & \\
\end{array}$ & $\begin{array}{cc}29 & 976 \\
282 & 905 \\
130 & 763 \\
& 15 \\
& \\
99,76\end{array}$ & $\begin{array}{cc}20 & 361 \\
159 & 691 \\
32 & 599 \\
& 19 \\
& 19 \\
67,76 & \end{array}$ & $\begin{array}{cc}28 & 243 \\
221 & 544 \\
50 & 258 \\
& \\
& 19 \\
94,00\end{array}$ \\
\hline
\end{tabular}



APPENDIX B

BI 

Table 81 - Cash Flow S

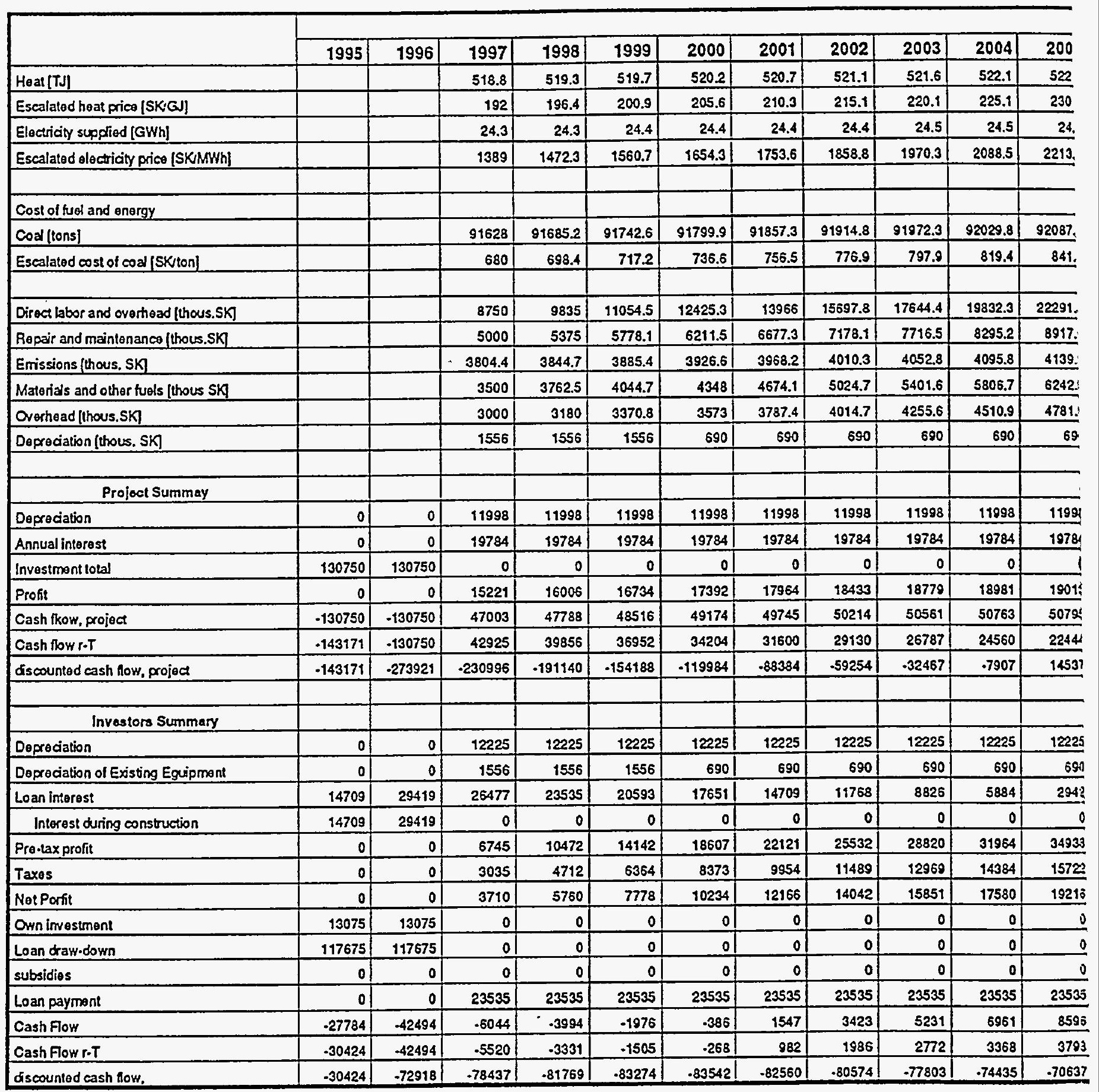

Ciscount Aate - 95

Inmaion - jo. 
mimary, Alternative 2, Load Variant 2

\begin{tabular}{|c|c|c|c|c|c|c|c|c|c|c|c|c|c|c|c|}
\hline & & Year & & & & & & & & & & & & & \\
\hline 2006 & 2007 & 2008 & 2009 & 2010 & 2011 & 2012 & 2013 & 2014 & 2015 & 2016 & 2017 & 2018 & 2019 & 2020 & 2021 \\
\hline 523 & 523.4 & 523.9 & 524.4 & 524.8 & 525.5 & 525.8 & 526.2 & 526.7 & 527.2 & 527.7 & 528.1 & 528.6 & 529.1 & 529.5 & 530 \\
\hline 235.6 & 241 & 246.6 & 252.2 & 258 & 264 & 270 & 276.3 & 282.6 & 289.1 & 295.8 & 302.5 & 309.9 & 316.6 & 323.9 & 331.4 \\
\hline 24.6 & 24.6 & 24.6 & 24.7 & 24.7 & 24.7 & 24.7 & 24.8 & 24.8 & 24.8 & 24.9 & 24.9 & 24.9 & 25 & 25 & 25.02 \\
\hline 2346.7 & 2487.5 & 2636.7 & 2794.9 & 2962.6 & 3140.4 & 3328.8 & 3528.5 & 3740.3 & 3964.7 & 4202.6 & 4454.7 & 4722 & 5005.3 & 5305.6 & 5624 \\
\hline & & & & & & & & & & & & & & & \\
\hline & & & & & & & & & & & & & & & \\
\hline 92144.9 & 92202.5 & 92250.2 & 92317.9 & 92375.6 & 92433.3 & 92491.1 & 92549 & 92606.8 & 92664.7 & 92722.7 & 92780.7 & $\$ 2838.7$ & 92896.7 & 92954.8 & 93013 \\
\hline 864.3 & 887.6 & 911.6 & 936.2 & 961.4 & 987.4 & 1014.1 & 1041.4 & 1009.5 & 1098.4 & 1128.1 & 1153.5 & 1189.8 & 1222 & 1255 & 1288.8 \\
\hline & & & & & & & & & & & & & & & \\
\hline 23628.9 & 25046.7 & 26549.5 & 28142.5 & 29831 & 31620.9 & 33518.1 & 35529.2 & 37661 & 39920.6 & 42315.8 & 44854.8 & 47546.1 & 50398.9 & 53422.8 & 56628.2 \\
\hline 9229.5 & 9552.5 & 9886.9 & 10232.9 & 10591.1 & 10961.7 & 11345.4 & 11742.5 & 12153.5 & 12578.9 & 13019.1 & 13474.8 & 13946.4 & 14434.5 & 14939.7 & 15462.6 \\
\hline 4183.1 & 4227.4 & 4272.2 & 4317.5 & 4363.3 & 4409.5 & 4456.3 & 4503.5 & 5411.2 & 4599.5 & 4648.2 & 4697.5 & 4747.3 & 4797.6 & 4848.5 & 4899.9 \\
\hline 6460.6 & 6686.8 & 6920.8 & 7163 & 7413.7 & 7673.2 & 7941.8 & 8219.7 & 8507.4 & 8805.2 & 9113.4 & 94324 & 9762.5 & 10104.2 & 10457.8 & 10823.8 \\
\hline 4925 & 5072.7 & 5224.9 & 5381.7 & 5543.1 & 5709.4 & 5880.7 & 6057.1 & 6238.8 & 6426 & 6618.8 & 6817.3 & 7021.9 & 7232.5 & 7449.5 & 7673 \\
\hline 690 & 690 & 690 & 690 & 690 & 690 & 690 & 690 & 690 & 690 & 690 & 690 & 690 & 690 & 690 & 690 \\
\hline & & & & & & & & & & & & & & & \\
\hline 11998 & 11998 & 11998 & 11998 & 11998 & 11998 & 11998 & 11998 & 11998 & 11998 & 11998 & 11998 & 11998 & 11998 & 11998 & 11998 \\
\hline 19784 & 19784 & 19784 & 19784 & 19784 & 19784 & 19784 & 19784 & 19784 & 19784 & 19784 & 19784 & 19784 & 19784 & 19734 & 19784 \\
\hline 0 & 0 & 0 & 0 & 0 & 0 & 0 & 0 & 0 & 0 & 0 & 0 & 0 & 0 & 0 & 0 \\
\hline 21023 & 23142 & 25379 & 27739 & 30232 & 32866 & 35649 & 38590 & 41701 & 44991 & 48472 & 52157 & 56057 & 60187 & 84561 & 68195 \\
\hline 52805 & 54924 & 57161 & 59521 & 62014 & 54648 & 67431 & 70372 & 72483 & 76773 & 80254 & 83933 & 87839 & 91969 & 96343 & 100977 \\
\hline 21307 & 20240 & 19237 & 18293 & 17406 & 16571 & 15785 & 15044 & 14346 & 13688 & 13067 & 12481 & 11928 & 11406 & 10911 & 10444 \\
\hline 35844 & 56084 & 75321 & $\$ 3614$ & 111020 & 127590 & 143375 & 158419 & 172765 & 186453 & 199520 & 212002 & 223930 & 235335 & 246247 & 258691 \\
\hline & & & & & & & & & & & & & & & \\
\hline 12225 & 12225 & 12225 & 12225 & 12225 & 12225 & 12225 & 12225 & 12225 & 12225 & 12225 & 12225 & 12225 & 12225 & 12225 & 12225 \\
\hline 690 & 690 & 690 & 690 & 690 & 690 & 690 & 690 & 690 & 690 & 690 & 650 & 690 & 690 & 690 & 690 \\
\hline 0 & 0 & 0 & 0 & 0 & - & 0 & 0 & 0 & 0 & 0 & 0 & 0 & 0 & 0 & 0 \\
\hline 0 & 0 & 0 & 0 & 0 & 0 & 0 & 0 & 0 & 0 & 0 & 0 & 0 & 0 & 0 & 0 \\
\hline 39890 & 42009 & 44245 & 46606 & 49099 & 51733 & 54515 & 57457 & 60568 & 63858 & 67339 & 71023 & 74924 & 79054 & 83428 & 88062 \\
\hline 17950 & 18904 & 19910 & 20973 & 22095 & 23280 & 24532 & 25856 & 27256 & 28736 & 30303 & 31960 & 33716 & 35574 & 37542 & 39628 \\
\hline 21939 & 23105 & 24335 & 25633 & 27005 & 28453 & 29984 & 31601 & 33312 & 35122 & 37036 & 39063 & 41208 & 43479 & 45885 & 48434 \\
\hline 0 & 0 & 0 & 0 & 0 & 0 & 0 & 0 & 0 & 0 & 0 & 0 & 0 & 0 & 0 & 0 \\
\hline 0 & 0 & 0 & 0 & 0 & 0 & 0 & 0 & 0 & 0 & 0 & 0 & 0 & 0 & 0 & 0 \\
\hline 0 & 0 & 0 & 0 & 0 & 0 & 0 & $\underline{0}$ & 0 & 0 & 0 & 0 & 0 & 0 & 0 & 0 \\
\hline 23535 & 0 & 0 & 0 & 0 & 0 & 0 & 0 & 0 & 0 & 0 & 0 & 0 & 0 & 0 & 0 \\
\hline 11319 & 36020 & 37250 & 38548 & 39920 & 41368 & 42899 & 44517 & 46227 & 48037 & 49952 & 51973 & 54123 & 56395 & 58800 & 61349 \\
\hline 4568 & 13274 & 12536 & 11847 & 11204 & 10504 & 10042 & 9517 & 9025 & 8565 & 8133 & 7729 & 7350 & 6994 & 6859 & 6345 \\
\hline$-65069 \mid$ & .52795 & .40260 & -28442 & -17208 & .6604 & 3438 & 12954 & 21979 & 30544 & $386 \pi$ & 46405 & 53756 & 60755 & 67400 & 73755 \\
\hline
\end{tabular}




\section{PARAMETERS OF ECONOMIC EFFECTIVENESS}

ALTERNATIVE 2

Table B.2 - Heat Supply According to Varlant 1

\begin{tabular}{|c|c|c|c|c|c|c|c|c|c|c|c|}
\hline & \multirow{2}{*}{$\begin{array}{l}\text { Cost of Coal } \\
\text { SK/ton }\end{array}$} & \multirow{2}{*}{$\begin{array}{l}\text { Real Interest (discount) } \\
\text { Inflation }\end{array}$} & \multirow{2}{*}{$\%$} & \multicolumn{2}{|c|}{2,0} & \multicolumn{2}{|c|}{5,0} & \multicolumn{2}{|c|}{9,5} & \multicolumn{2}{|c|}{12,0} \\
\hline & & & & 3 & 18 & 3 & 18 & 3 & 18 & 3 & 18 \\
\hline & 467 Sk/ton & $\begin{array}{l}\text { Average Annual Profit } \\
\text { Discounted Profit (life) } \\
\text { Discounted Cash Flow (life) } \\
\text { Payback Period } \\
\text { Return on Investment }\end{array}$ & $\begin{array}{l}\text { thous. Sk } \\
\text { thous. Sk } \\
\text { thous. Sk } \\
\text { Years } \\
\%\end{array}$ & $\begin{array}{cc}15 & 953 \\
311 & 463 \\
289 & 846 \\
& \\
& 13 \\
61,01\end{array}$ & $\begin{array}{cc}27 & 756 \\
541 & 898 \\
508 & 328 \\
& \\
& 12 \\
106,14\end{array}$ & $\begin{array}{cc}16 & 916 \\
& \\
238 & 411 \\
176 & 591 \\
& \\
& 13 \\
64,69\end{array}$ & $\begin{array}{cc}27 & 105 \\
382 & 016 \\
296 & 213 \\
& 13 \\
& 10 \\
103,65\end{array}$ & $\begin{array}{cc}17 & 477 \\
164 & 937 \\
68 & 308 \\
& 16 \\
66,83\end{array}$ & $\begin{array}{cc}25 & 398 \\
239 & 695 \\
108 & 425 \\
& 15 \\
97,12\end{array}$ & $\begin{array}{cc}17 & 423 \\
136 & 653 \\
27 & 028 \\
& \\
& 19 \\
66,63 & \end{array}$ & $\begin{array}{cc}24 & 206 \\
189 & 852 \\
41 & 768 \\
& 19 \\
& \\
92,57\end{array}$ \\
\hline & 680 Sknon & $\begin{array}{l}\text { Average Annual Profit } \\
\text { Discounted Profit (life) } \\
\text { Discounted Cash Flow (life) } \\
\text { Payback Period } \\
\text { Return on Investment }\end{array}$ & $\begin{array}{l}\text { thous. Sk } \\
\text { thous. Sk } \\
\text { thous. Sk } \\
\text { Years } \\
\%\end{array}$ & $\begin{array}{cc}15 & 741 \\
& \\
307 & 324 \\
285 & 707 \\
& \\
& 13 \\
60,20\end{array}$ & $\begin{array}{cc}27 & 544 \\
537 & 759 \\
504 & 189 \\
& 12 \\
105,33\end{array}$ & $\begin{array}{cc}16 & 781 \\
236 & 504 \\
174 & 684 \\
& 13 \\
64,17^{13}\end{array}$ & $\begin{array}{cc}26 & 970 \\
380 & 108 \\
294 & 305 \\
& 13 \\
103,13\end{array}$ & $\begin{array}{cc}17 & 411 \\
164 & 314 \\
67 & 685 \\
& \\
& 16 \\
66,58\end{array}$ & $\begin{array}{cc}25 & 324 \\
238 & 997 \\
107 & 727 \\
& \\
& 15 \\
96,84\end{array}$ & $\begin{array}{cc}17 & 394 \\
136 & 420 \\
26 & 795 \\
& 19 \\
& \\
66,51\end{array}$ & $\begin{array}{cc}24 & 183 \\
189 & 674 \\
41 & 590 \\
& 19 \\
& 19 \\
92,48\end{array}$ \\
\hline & 850 Skiton & $\begin{array}{l}\text { Average Annual Profit } \\
\text { Discounted Profit (life) } \\
\text { Discounted Cash Flow (life) } \\
\text { Payback Period } \\
\text { Return on Investment }\end{array}$ & $\begin{array}{l}\text { thous. Sk } \\
\text { thous. Sk } \\
\text { thous. Sk } \\
\text { Years } \\
\%\end{array}$ & $\begin{array}{cc}15 & 584 \\
& \\
304 & 244 \\
282 & 627 \\
& \\
& 13 \\
59,59\end{array}$ & $\begin{array}{cc}27 & 387 \\
534 & 679 \\
501 & 109 \\
& 12 \\
104,73\end{array}$ & $\begin{array}{cc}16 & 662 \\
234 & 837 \\
173 & 017 \\
& 13 \\
63,72\end{array}$ & $\begin{array}{cc}26 & 851 \\
& \\
378 & 441 \\
292 & .638 \\
& 13 \\
102,68\end{array}$ & $\begin{array}{cc}17 & 368 \\
163 & 916 \\
67 & 287 \\
& 15 \\
66,42\end{array}$ & $\begin{array}{cc}25 & 270 \\
238 & 492 \\
107 & 223 \\
& 15 \\
& 15 \\
96,64^{2} & \end{array}$ & $\begin{array}{cc}17 & 380 \\
136 & 316 \\
26 & 691 \\
& \\
& 19 \\
66,46\end{array}$ & $\begin{array}{cc}24 & 150 \\
189 & 413 \\
41 & 329 \\
& 19 \\
& 92,35\end{array}$ \\
\hline & 1275 Sklton & $\begin{array}{l}\text { Average Annual Profit } \\
\text { Dlscounted Profit (life) } \\
\text { Discounted Cash Flow (life) } \\
\text { Payback Period } \\
\text { Return on Investment }\end{array}$ & $\begin{array}{l}\text { thous. Sk } \\
\text { thous. Sk } \\
\text { thous. Sk } \\
\text { Years } \\
\%\end{array}$ & $\begin{array}{cc}15 & 171 \\
& \\
296 & 186 \\
274 & 569 \\
& \\
& 13 \\
& 58,01\end{array}$ & $\begin{array}{cc}26 & 974 \\
526 & 621 \\
493 & 051 \\
& 12 \\
103,15\end{array}$ & $\begin{array}{cc}16 & 378 \\
230 & 837 \\
169 & 016 \\
& 13 \\
62,63\end{array}$ & $\begin{array}{cc}26 & 579 \\
374 & 608 \\
288 & 805 \\
& 13 \\
101,64\end{array}$ & $\begin{array}{cc}17 & 246 \\
162 & 762 \\
66 & 133 \\
& 16 \\
65,95\end{array}$ & $\begin{array}{cc}25 & 160 \\
237 \cdot & 445 \\
106 & 176 \\
& \\
& 15 \\
96,21 & \end{array}$ & $\begin{array}{cc}17 & 319 \\
135 & 837 \\
26 & 212 \\
& \\
& 19 \\
66,23 & \end{array}$ & $\begin{array}{cc}24 & 103 \\
189 & 043 \\
40 & 959 \\
& \\
& 19 \\
92,17\end{array}$ \\
\hline
\end{tabular}


PARAMETERS OF ECONOMIC EFFECTIVENESS

ALTERNATIVE 2

Table B.2 - Heat Supply According to Variant 2

\begin{tabular}{|c|c|c|c|c|c|c|c|c|c|c|}
\hline \multirow{2}{*}{$\begin{array}{c}\text { Cost of Coal } \\
\text { SK/ton }\end{array}$} & \multirow{2}{*}{$\begin{array}{l}\text { Real Interest (discount) } \\
\text { Inflation }\end{array}$} & \multirow{2}{*}{$\%$} & \multicolumn{2}{|c|}{2,0} & \multicolumn{2}{|c|}{5,0} & \multicolumn{2}{|c|}{9,5} & \multicolumn{2}{|c|}{12,0} \\
\hline & & & 3 & 18 & 3 & 18 & 3 & 18 & 3 & 18 \\
\hline 467 Skfton & $\begin{array}{l}\text { Average Annual Profit } \\
\text { Discounted Profit (life) } \\
\text { Discounted Cash Flow (life) } \\
\text { Payback Period } \\
\text { Return on Investment }\end{array}$ & $\begin{array}{l}\text { thous. Sk } \\
\text { thous. Sk } \\
\text { thous. Sk } \\
\text { Years } \\
\%\end{array}$ & $\begin{array}{cc}18 & 229 \\
& \\
355 & 895 \\
334 & 278 \\
& 13 \\
& 13 \\
69,71\end{array}$ & $\begin{array}{cc}30 & 109 \\
& \\
587 & 824 \\
554 & 254 \\
& 12 \\
115,14\end{array}$ & $\mid \begin{array}{cc}18 & 473 \\
260 & 358 \\
198 & 538 \\
& 14 \\
& 14 \\
70,64\end{array}$ & $\begin{array}{cc}28 & 757 \\
405 & 300 \\
319 & 497 \\
& 13 \\
& 109,97\end{array}$ & $\begin{array}{cc}18 & 135 \\
171 & 148 \\
74 & 520 \\
& \\
& 16 \\
& \\
69 & \end{array}$ & \begin{tabular}{|cc}
26 & 152 \\
246 & 809 \\
115 & 539 \\
& 16 \\
& 100,01
\end{tabular} & $\begin{array}{cc}17 & 683 \\
138 & 691 \\
29 & 066 \\
& 19 \\
67,62\end{array}$ & $\begin{array}{rr}24 & 504 \\
& \\
192 & 188 \\
44 & 104 \\
& 19 \\
93,71\end{array}$ \\
\hline $680 \mathrm{Sk} / \mathrm{ton}$ & $\begin{array}{l}\text { Average Annual Profit } \\
\text { Discounted Profit (life) } \\
\text { Discounted Cash Flow (life) } \\
\text { Payback Period . } \\
\text { Return on Investment }\end{array}$ & $\begin{array}{l}\text { thous. Sk } \\
\text { thous. Sk } \\
\text { thous. Sk } \\
\text { Years } \\
\%\end{array}$ & $\begin{array}{cc}17 & 952 \\
& \\
350 & 482 \\
328 & 865 \\
& \\
& 13 \\
68,65\end{array}$ & $\begin{array}{cc}29 & 831 \\
& \\
582 & 412 \\
548 & 842 \\
& \\
& 12 \\
114,08\end{array}$ & \begin{tabular}{cc}
18 & 283 \\
& \\
257 & 679 \\
195 & 859 \\
& \\
& \multicolumn{1}{c}{14} \\
69,92 &
\end{tabular} & $\begin{array}{cc}28 & 545 \\
& \\
402 & 306 \\
316 & 502 \\
& 13 \\
& 109,16\end{array}$ & $\begin{array}{cc}18 & 054 \\
170 & 384 \\
73 & 755 \\
& 16 \\
& 16 \\
69,04\end{array}$ & \begin{tabular}{|cc}
26 & 037 \\
& \\
245 & 731 \\
114 & 461 \\
& 16 \\
& \\
99,57
\end{tabular} & $\begin{array}{cl}17 & 651 \\
& \cdot \\
138 & 437 \\
28 & 812 \\
& \\
& 19 \\
67,50 & \end{array}$ & $\begin{array}{cc}24 & 479 \\
& \\
191 & 996 \\
43 & 912 \\
& 19 \\
& 93,61\end{array}$ \\
\hline 850 Sk/ton & $\begin{array}{l}\text { Average Annual Profit } \\
\text { Discounted Profit (life) } \\
\text { Discounted Cash Flow (life) } \\
\text { Payback Period } \\
\text { Return on Investment }\end{array}$ & $\begin{array}{l}\text { thous. Sk } \\
\text { thous. Sk } \\
\text { thous. Sk } \\
\text { Years } \\
\%\end{array}$ & $\begin{array}{cc}17 & 728 \\
346 & 107 \\
324 & 490 \\
& 13 \\
& 13 \\
67,79\end{array}$ & $\begin{array}{cc}29 & 607 \\
578 & 037 \\
544 & 467 \\
& 12 \\
113,22\end{array}$ & $\begin{array}{cc}18 & 128 \\
& \\
255 & 502 \\
193 & 682 \\
& 14 \\
& 14 \\
69,32\end{array}$ & $\begin{array}{cc}28 & 380 \\
& \\
399 & 990 \\
314 & 187 \\
- & 13 \\
108,53\end{array}$ & $\begin{array}{cc}17 & 986 \\
169 & 748 \\
73 & 119 \\
& \\
& 16 \\
68,78\end{array}$ & $\begin{array}{cc}25 & 988 \\
& \\
245 & 261 \\
113 & 991 \\
& \\
& 16 \\
99,38\end{array}$ & $\begin{array}{cc}17 & 622 \\
138 & 215 \\
28 & 590 \\
& \\
& 19 \\
67,39\end{array}$ & $\begin{array}{c}24453 \\
191792 \\
43708 \\
19 \\
93,51\end{array}$ \\
\hline 1275 Sk/ton & $\begin{array}{l}\text { Average Annual Profit } \\
\text { Discounted Profit (life) } \\
\text { Discounted Cash Flow (life) } \\
\text { Payback·Period } \\
\text { Return on Investment }\end{array}$ & $\begin{array}{l}\text { thous. Sk } \\
\text { thous: Sk } \\
\text { thous. Sk } \\
\text { Years } \\
\%\end{array}$ & $\begin{array}{cc}17 & 175 \\
335 & 317 \\
313 & 700 \\
& 13 \\
& 13 \\
65,68\end{array}$ & $\begin{array}{cc}29 & 066 \\
& \\
567 & 466 \\
533 & 896 \\
& \\
& 12 \\
111,15\end{array}$ & $\begin{array}{cc}17 & 742 \\
250 & 059 \\
188 & 239 \\
& \\
& 14 \\
67,85\end{array}$ & $\begin{array}{cc}27 & 994 \\
& \\
394 & 437 \\
308 & 744 \\
& \\
& 15 \\
107,05\end{array}$ & $\begin{array}{cc}17 & 835 \\
168 & 323 \\
71 & 694 \\
& 16 \\
& 16 \\
68,20\end{array}$ & $\begin{array}{cc}25 & 789 \\
243 & 390 \\
112 & 121 \\
& 15 \\
& 15 \\
98,62 & \end{array}$ & $\begin{array}{cc}17 & 568 \\
137 & 792 \\
28 & 167 \\
& \\
& 19 \\
67,18\end{array}$ & $\begin{array}{cc}24 & 379 \\
& \\
191 & 211 \\
43 & 127 \\
& \\
& 19 \\
93,23\end{array}$ \\
\hline
\end{tabular}


PARAMETERS OF ECONOMIC EFFECTIVENESS

ALTERNATIVE 2

Table B.2 - Heat Supply According to Variant 3

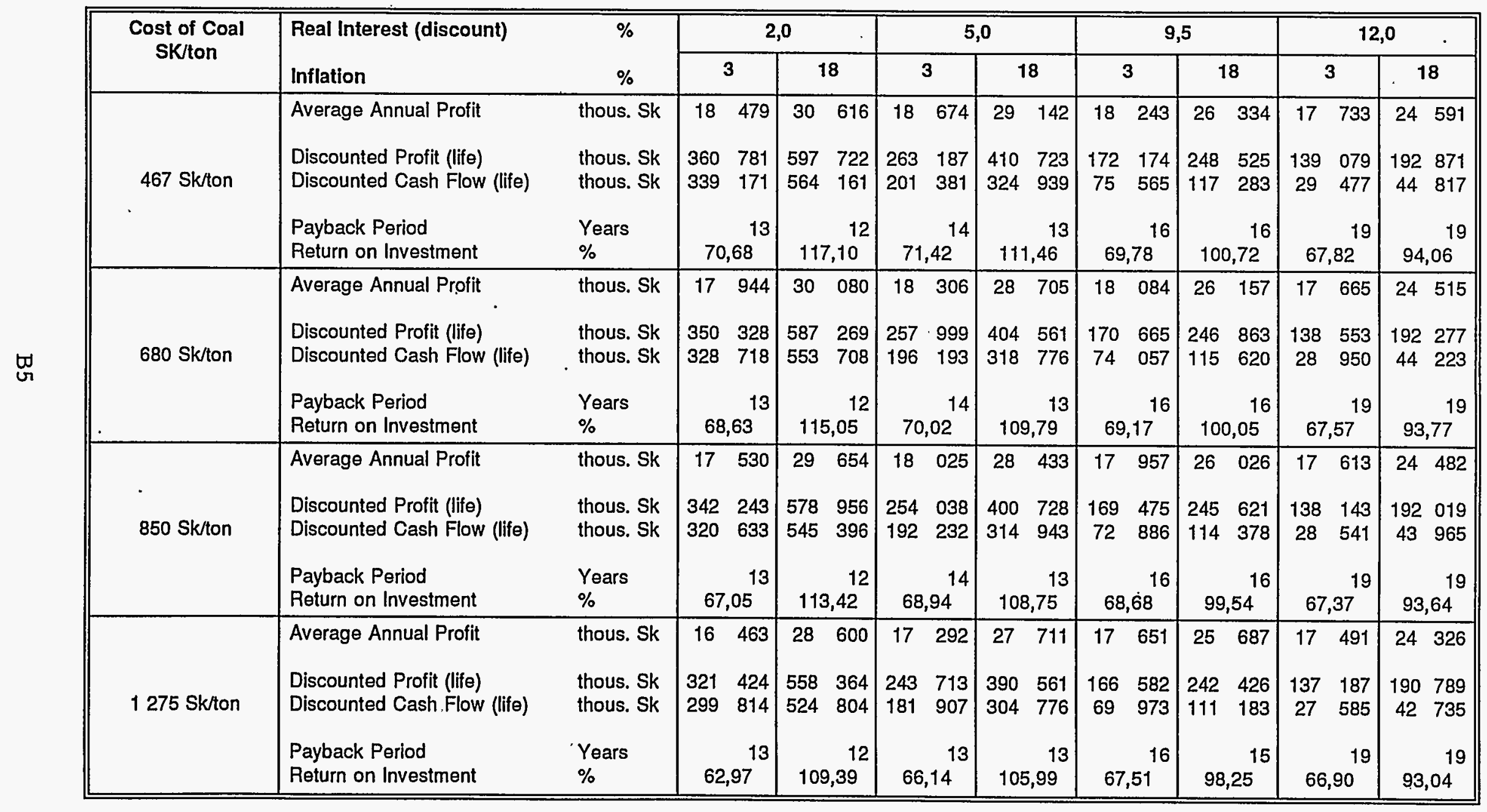




\section{APPENDIX C}

Cl 


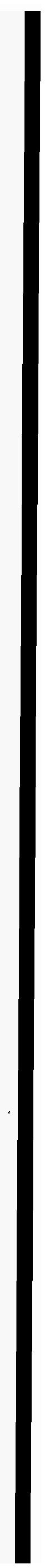


Table C1 - Cash Flon

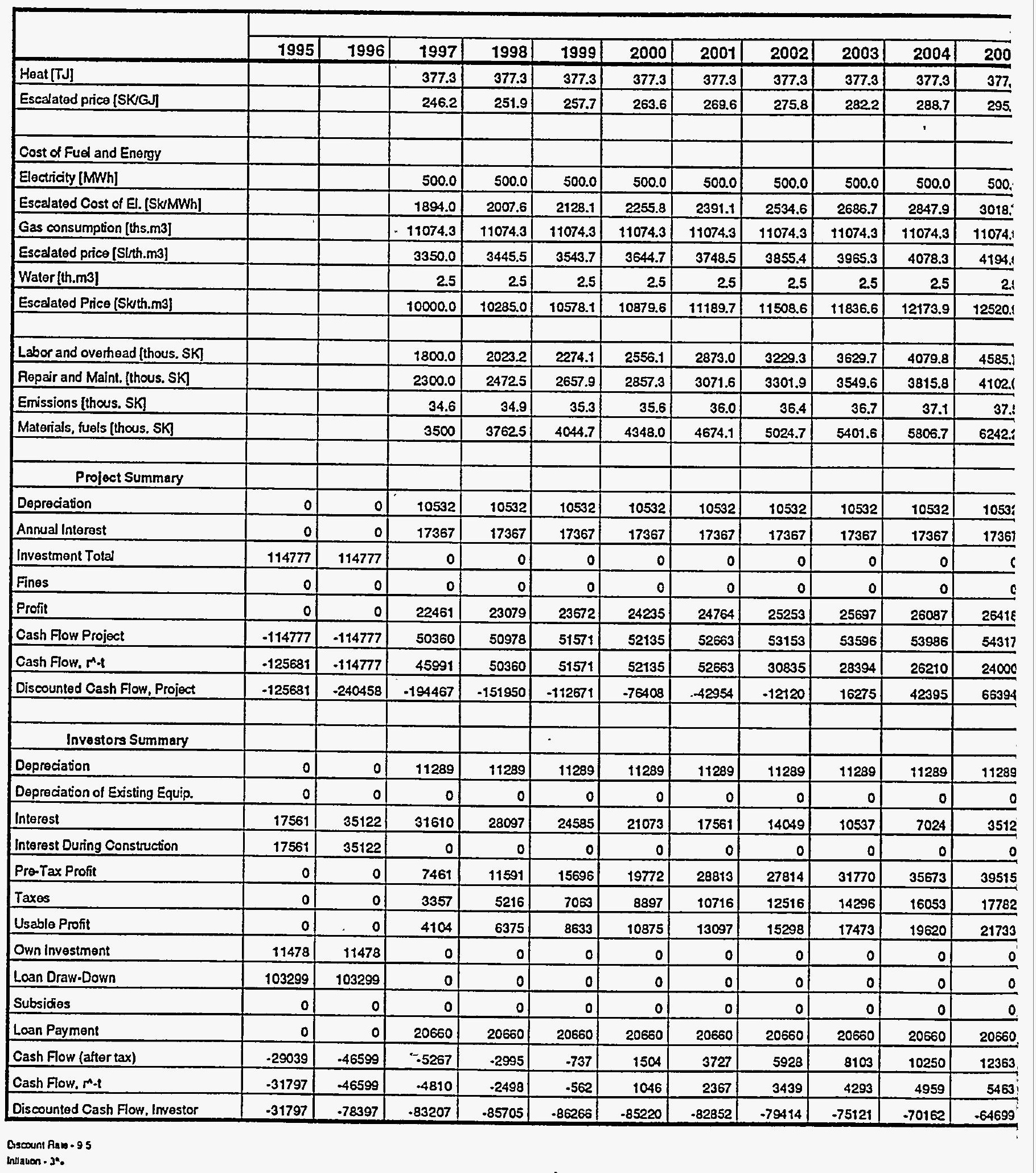


Summary, Alternative 3, Load Variant 3

\begin{tabular}{|c|c|c|c|c|c|c|c|c|c|c|c|c|c|c|c|}
\hline \multicolumn{16}{|c|}{ Year } \\
\hline 2006 & 2007 & 2008 & 2009 & 2010 & 2011 & 2012 & 2013 & 2014 & 2015 & 2016 & 2017 & 2018 & 2019 & 2020 & 2021 \\
\hline 377.3 & 377.3 & 377.3 & 377.3 & 377.3 & 377.3 & 377.3 & 377.3 & .377 .3 & 377.3 & 377.3 & 377.3 & 377.3 & 377.3 & 377.3 & 377.3 \\
\hline 302.1 & 309.1 & 316.2 & 323.4 & 330.9 & 338.5 & 346.3 & 354.2 & 362.4 & 370.7 & 379.2 & 388.0 & 396.9 & 406.0 & 415.4 & 424.9 \\
\hline & & & & . & & & & & & & & & & & \\
\hline 500.0 & 500.0 & 500.0 & 500.0 & 500.0 & 500.0 & 500.0 & 500.0 & $5 c 0.0$ & 500.0 & 500.0 & 500.0 & 500.0 & 500.0 & 500.0 & 500.0 \\
\hline 3199.9 & 3391.9 & 3595.4 & 3811.1 & 4039.8 & 4282.2 & 4539.1 & 4811.4 & 5100.1 & 5406.1 & 5730.5 & 6074.3 & 6438.8 & 6825.1 & 7234.6 & 7668.7 \\
\hline 11074.3 & 11074.3 & 11074.3 & 11074.3 & 11074.3 & 11074.3 & 11074.3 & 11074.3 & 11074.3 & 11074.3 & 11074.3 & 11074.3 & 11074.3 & 11074.3 & 11074.3 & 11074.3 \\
\hline 4253.2 & 4312.8 & 4373.1 & 4434.4 & 4495.4 & 4559.4 & 4623.2 & 4687.9 & 4753.6 & 4820.1 & 4887.6 & 4956.0 & 5025.4 & 5095.8 & 5167.1 & 5239.5 \\
\hline 2.5 & 2.5 & 25 & 2.5 & 25 & 2.5 & 2.5 & 2.5 & 2.5 & 2.5 & 2.5 & 2.5 & 2.5 & 2.5 & 2.5 & 2.5 \\
\hline 12696.2 & 12873.9 & 13054.1 & 13236.9 & 134222 & 13610.1 & 13800.7 & 13993.9 & 14189.8 & 14388.4 & 14589.9 & 14794.1 & 15001.3 & 15211.3 & 15424.2 & 15640.2 \\
\hline 4860.8 & 5152.5 & 5461.6 & 5789.3 & 6136.7 & 6504.9 & 6895.2 & 7308.9 & 7747.4 & 8212.2 & 8705.0 & 9227.3 & 9780.9 & 10367.8 & 10989.8 & 11649.2 \\
\hline 4245.6 & 4394.2 & 4548.0 & 4707.1 & 4871.9 & 5042.4 & 5218.9 & 5401.5 & 5590.6 & 5786.3 & 5988.8 & 6198.4 & 6415.3 & 6639.9 & 6872.3 & 71.12 .8 \\
\hline 37.8 & 38.2 & 38.6 & 39.0 & 39.4 & 39.8 & 40.2 & 40.6 & 41.0 & 41.4 & 41.8 & 42.2 & 42.6 & 43.1 & 43.5 & 43.9 \\
\hline 6460.6 & 6686.8 & 6920.8 & 7163.0 & 7413.7 & 7673.2 & 7941.8 & 8219.7 & 8507.4 & 8805.2 & 9113.4 & 9432.4 & $97 \approx 2.5$ & 10104.2 & 10457.8 & 10823.8 \\
\hline & & & & & & & & & & & & & & & \\
\hline 10532 & 10532 & 10532 & 10532 & 10532 & 10532 & 10532 & 10532 & 10532 & 10532 & 10532 & 10532 & 10532 & 10532 & 10532 & 10532 \\
\hline 17367 & 17367 & 17367 & 17367 & 17367 & 17367 & 17367 & 17367 & 17367 & 17367 & 17367 & 17367 & 17367 & 17367 & 17367 & 17367 \\
\hline 0 & 0 & 0 & 0 & 0 & 0 & 0 & 0 & 0 & 0 & 0 & 0 & 0 & 0 & 0 & 0 \\
\hline 0 & 0 & 0 & 0 & 0 & 0 & 0 & 0 & 0 & $\therefore 0$ & 0 & 0 & 0 & 0 & 0 & 0 \\
\hline 27811 & 29227 & 30655 & 32126 & 33608 & 35111 & $36 \approx 6$ & 38180 & 39743 & 41326 & 42926 & 44543 & 46176 & 47823 & 49484 & 51157 \\
\hline 55710 & 57126 & 58565 & 60025 & 61507 & 63011 & 64535 & 66079 & 64643 & 69225 & 70825 & 72442 & 74075 & 75722 & 77383 & 79056 \\
\hline 22480 & 21051 & 19709 & 18448 & 17264 & 16151 & 15107 & 14126 & 13206 & 12342 & 11532 & 10772 & 80059 & 9391 & 8764 & 8177 \\
\hline 88874 & 109926 & 129535 & 148083 & 165346 & 181497 & 196504 & 210730 & 223936 & 236278 & 247810 & 331141 & 268641 & 278032 & 286796 & 294973 \\
\hline & & & & & & & & & & & & & & & \\
\hline 11289 & 11289 & 11289 & 11289 & 11289 & 11289 & 11289 & 11289 & 11289 & 11289 & 11289 & 11289 & 11289 & 11289 & 11289 & 11289 \\
\hline 0 & 0 & 0 & 0 & 0 & 0 & 0 & 0 & 0 & 0 & 0 & 0 & 0 & 0 & 0 & 0 \\
\hline 0 & 0 & 0 & 0 & 0 & 0 & 0 & 0 & 0 & 0 & 0 & 0 & 0 & 0 & 0 & 0 \\
\hline 0 & 0 & 0 & 0 & 0 & 0 & 0 & 0 & 0 & 0 & 0 & 0 & 0 & 0 & 0 & $\underline{0}$ \\
\hline 44421 & 45837 & 47275 & 48736 & 50218 & 51721 & 53245 & 54790 & 56053 & 57936 & 59536 & 61153 & 62786 & 64433 & 66094 & 67767 \\
\hline 19589 & 20527 & 21274 & 21931 & 22598 & 23275 & 23950 & 24655 & 25359 & 26071 & 26791 & 27519 & 28253 & 28995 & 29742 & 30495 \\
\hline 24431 & 25210 & 26001 & 26805 & $27 \approx 20$ & 28447 & 29285 & 30134 & 30994 & 31865 & 32745 & 33634 & 34532 & 35438 & 36352 & 37272 \\
\hline 0 & 0 & 0 & 0 & 0 & 0 & 0 & 0 & 0 & 0 & 0 & 0 & 0 & 0 & 0 & 0 \\
\hline 0 & 0 & 0 & 0 & 0 & 0 & 0 & 0 & 0 & 0 & 0 & 0 & 0 & 0 & 0 & 0 \\
\hline 0 & 0 & 0 & 0 & 0 & 0 & 0 & 0 & 0 & 0 & 0 & 0 & 우 & 0 & 0 & 0 \\
\hline 20660 & 0 & 0 & 0 & 0 & 0 & 0 & 0 & 0 & 0 & 0 & 0 & 0 & 0 & 0 & 0 \\
\hline 15051 & 36500 & 37291 & 38094 & 38909 & 39736 & 40574 & 41424 & 42234 & 43154 & 44034 & 44923 & 45822 & $4672 B$ & 47641 & 48551 \\
\hline 6077 & 13450 & 12550 & 11708 & 10921 & 10185 & 9498 & 8855 & $8 \hat{c} 55$ & 7694 & 7170 & 6680 & 6222 & 5795 & 5396 & 5023 \\
\hline-58622 & -45172 & -32622 & -20914 & -9993 & 192 & 9690 & 18545 & 26800 & 34494 & 41664 & 48344 & 54566 & 60361 & 65757 & 70780 \\
\hline
\end{tabular}


PARAMETERS OF ECONOMIC EFFECTIVENESS

Table C.2 - Heat Supply, According to Alternative 3, $377280 \mathrm{GJ} /$ year (comparable with Variant 1)

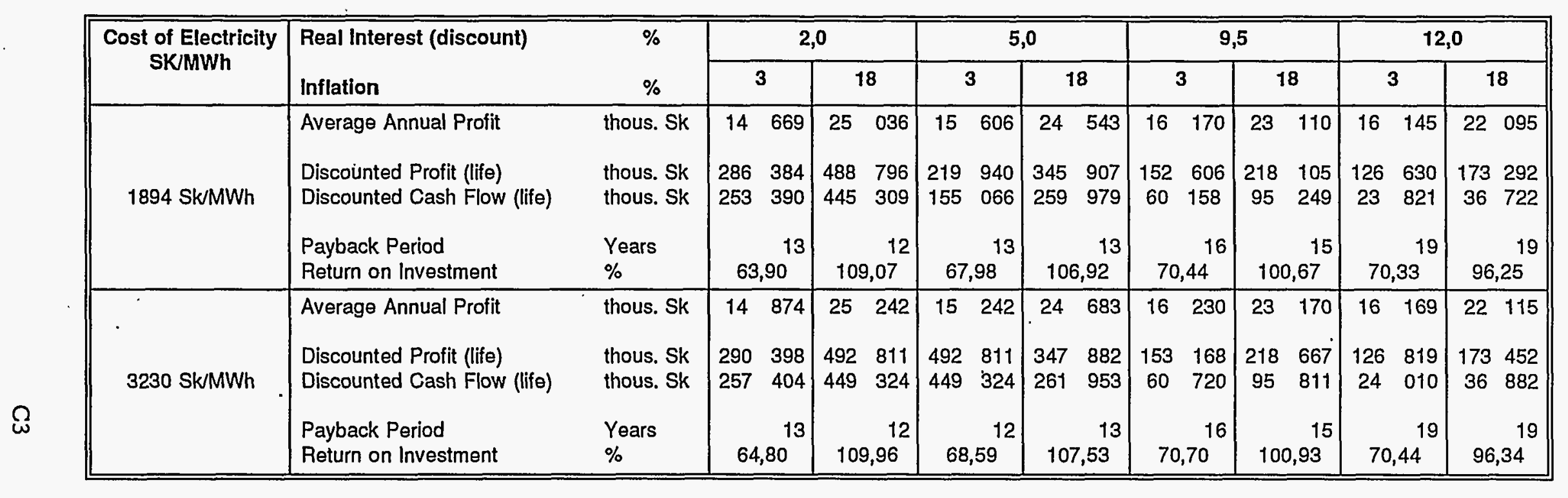


